\title{
Proyecto Utica (Túnez). Excavaciones en la ciudad fenicio-púnica. Resultados de la campaña de 2016
}

\section{Utica Project (Tunisia). Excavations in the Phoenician-Punic city. Results of the 2016 season}

\author{
JOSÉ LUIS LÓPEZ CASTRO \\ Universidad de Almería \\ jllopez@ual.es \\ https://orcid.org/0000-0002-8527-7898 \\ FAOUZZI ABIDI \\ Université de Tunis \\ fawzibidi@hotmail.fr \\ BARTOlOMÉ MORA SERRANO \\ Universidad de Málaga \\ barmora@uma.es \\ https://orcid.org/0000-0002-0909-9225 \\ AMPARO SÁNCHEZ MORENO \\ Universidad de Almería \\ asmoreno@ual.es \\ https://orcid.org/00oo-0001-6267-4615
}

\author{
IMED BEN JERBANIA \\ Institut National du Patrimoine \\ ibenjerbania@yahoo.fr \\ KAOUTHER JENDOUBI \\ Institut National du Patrimoine \\ kaoutherjendoubi123@gmail.com \\ ANA MARÍA NIVEAU DE VILLEDARY \\ Y MARIÑAS \\ Universidad de Cádiz \\ anamaria.niveau@uca.es \\ https://orcid.org/0000-0002-8888-1169 \\ MOUNIR TORCHANI \\ Institut National du Patrimoine
}

\author{
ALFREDO MEDEROS MARTíN \\ Universidad Autónoma de Madrid \\ alfredo.mederos@uam.es \\ https://orcid.org/0000-0002-0036-7940 \\ WALID KHALFALLI \\ Institut National du Patrimoine \\ dematoo6@yahoo.fr \\ LUIS Alberto RUIZ CABRERo \\ Universidad Complutense \\ laruiz@ucm.es \\ https://orcid.org/0ooo-0001-6457-1898
}

\section{Resumen}

Se presentan los resultados de la campaña de excavaciones de 2016 en Utica (Túnez). En la Zona ll se continuó excavando en el corte 21 buscando la delimitación del muro perimetral de un edificio fenicio arcaico. Se continuó la excavación al norte de dicho corte de una fosa romana. En la zona I se continuó la excavación en los sectores 21 y 22 del corte 10. El primero dio como resultado un pavimento perteneciente a una vivienda quizá del siglo III-II a. C. En el segundo sector, situado al extremo noreste del corte, se localizó una posible calle que delimitaría la manzana urbana fenicio-púnica. En el corte 11 se efectuó una ampliación al norte que descubrió una plataforma de cimentación hecha con grandes bloques, posiblemente para sostener el muro perimetral noreste del templo del siglo IV a. C. Por último, se efectuó una prospección geofísica en las zonas I y II para comprobar los límites de la ciudad y la existencia de estructuras antiguas en las inmediaciones de la antigua línea de costa.

Palabras clave: Utica, Norte de África, periodo fenicio, área urbana, edificios monumentales, prospección geofísica

\section{Abstract}

In the article are presented the results of the excavation season of 2016 at Utica (Tunisia). In Zone II the excavation went on in square 21 searching the delimitation of a perimetral wall of an archaic Phoenician building. North of the square was continued the excavation of a Roman pit. In Zone I, square 10, the excavation focused in sectors 21 and 22. The first one gave as a result a pavement that belongs to a house maybe of the $3^{\text {rd }}$ and $2^{\text {nd }}$ centuries BC. In the second sector, placed at the north-east extreme of the square, was localized a possible street which could delimitate an urban Phoenician-Punic block. In square 11 an enlargement in the north area discovered a foundation platform built with ashlars, likely to support the north-east perimetral wall of the temple of $4^{\text {th }}$ century BC. Finally, a geophysical survey was done in zones I and II to check the limits of the city and the existence of ancient structures in the surroundings of the ancient coastal line.

Key words: Utica, North Africa, Phoenician period, Urban area, monumental buildings, geophysical prospection 


\section{Introducción ${ }^{1}$}

El yacimiento arqueológico de Utica se sitúa al norte de Túnez, en la región de Bizerta, en las coordenadas $37^{\circ} \circ 3^{\prime} 31^{\prime \prime} \mathrm{N}$ y $10^{\circ} 03^{\prime} 47^{\prime \prime}$ E. Ocupa un promontorio situado en la antigua desembocadura el río Bagradas, el actual Mdjerda. La antigua bahía de Utica sufrió a lo largo de la Historia un proceso de colmatación por los aportes fluviales, que ha provocado que actualmente las ruinas de la ciudad antigua se encuentren a I $2 \mathrm{~km}$ del mar (Delile et alii, 20I5; Pleuger et alii, 20I9) (figura I). La extensión del sitio arqueológico de Utica es de 105 hectáreas en un perímetro de 5093 metros, que en su mayoría corresponde a la Utica romana.

Según las fuentes clásicas Utica fue una de las más antiguas colonias tirias en el Mediterráneo Occidental, cuya fundación fue efectuada hacia IIoo a. C. (Mir. Ausc., I34; Joseph., Ap. I, r8; Vell. Pat., I, 2, 3; Plin., HN XVI, 216). Sus ruinas fueron conocidas por viajeros de diversas naciones desde el siglo xvII, si bien los inicios de la exploración arqueológica se remontan al siglo xIx. Fue en el siglo $\mathrm{xx}$ cuando se efectuaron extensas exploraciones arqueológicas. Hasta los años 60 se excavaron varios sectores de la ciudad romana por diversos investigadores franceses, cuya síntesis de estas investigaciones se debe a André Lézine (1968, i970; García Sánchez, 20r6). Por lo que respecta a la Utica fenicio-púnica, en los años 50 del siglo xx se excavaron varias necrópolis datadas desde mediados del siglo vir a. C. (Cintas, I951, I954; Peserico, I996) y aunque la ciudad fenicia no fue nunca excavada, diversos estudios proponían su localización en la colina más elevada del promontorio norte.

Los únicos testimonios tangibles del pasado fenicio-púnico de Utica se recogieron en trabajos de Lézine en la ciudad romana, bajo la cual descubrió restos constructivos de época tardofenicia, así

1 Este trabajo es resultado del proyecto de investigación HAR20I4-53350-P: Utica fenicio-púnica. Urbanismo y economía durante el I milenio $A C$ financiado por el Ministerio de Ciencia, Innovación y Universidades español. Es también resultado del grupo de investigación HUM-74I de la Universidad de Almería adscrito al Campus de Excelencia Internacional CEI-Mar y al Centro de Investigación CySoc. como otros de la ciudad fenicia bajo el área del foro romano, que podrían remontarse al siglo vi a. C. (Lézine, 1968: 103). Las excavaciones efectuadas desde mediados de los años 80 del siglo xx y a inicios de este siglo por parte de los conservadores de Utica, F. Chelbi y T. Redissi (Chelbi, 1996; Ben Jerbania y Redissi, 20I4), aunque permanecen casi inéditas, contribuyen a situar a grandes rasgos el área donde se ubicaba la antigua ciudad fenicio-púnica. Ello se ha visto confirmado en las recientes investigaciones iniciadas en 2010 por un equipo hispano-tunecino formado por investigadores del Institut National du Patrimoine de Túnez y de varias universidades españolas agrupados en el Centro de Estudios Fenicios y Púnicos, con el propósito de investigar la urbe fenicio-púnica.

El área de la ciudad fenicio-púnica donde se desarrolla este proyecto iniciado en 2010 se sitúa en el extremo norte de la antigua península localizada en la margen izquierda de la desembocadura del antiguo río Bagradas, ocupando una colina de unas io hectáreas (figura 2). En 2010 se efectuó una prospección geofísica en el área prevista en Utica, la cual orientó las posteriores excavaciones (López Castro et alii, 20I2; Teixidó et alii, 2012). Se han efectuado ocho campañas de excavación en 2012 (López Castro et alii, 2014), 20I3, $20 \mathrm{I}_{4}$ (López Castro et alii, 2015), 2015 (López Castro et alii, 2016a), 2016, 2017 (López Castro et alii, 2020a), 20I8 y 2019.

En este artículo presentamos los resultados de la campaña de 20r6. La financiación ha sido aportada por el programa de excavaciones arqueológicas en el exterior del Ministerio de Educación, Cultura y Deporte (campañas de 20IO, 20I2, 20I4, 2015, 2016 y 20I9), la Fundación Palarq (campañas de 2018 y 20I9) y por proyectos concedidos a la Universidad de Almería por diferentes organismos (campañas de 20I3, 20I7 y 20I8).

Las excavaciones (figura 2) han dado como resultado el descubrimiento en la Zona II, cortes 20 y 2I, de un pozo de agua relleno con materiales arqueológicos del siglo ix a. C. (López Castro et alii, 2016b, 2020b) que correspondían a los deshechos de un banquete colectivo (Cardoso et alii, 20I6). Junto a este se localizaron los restos de dos fases constructivas fenicias (López Castro et alii, 2020c), la más antigua de las cuales pertenecería a un edificio cuya delimitación se inició en la campaña de 2016. 


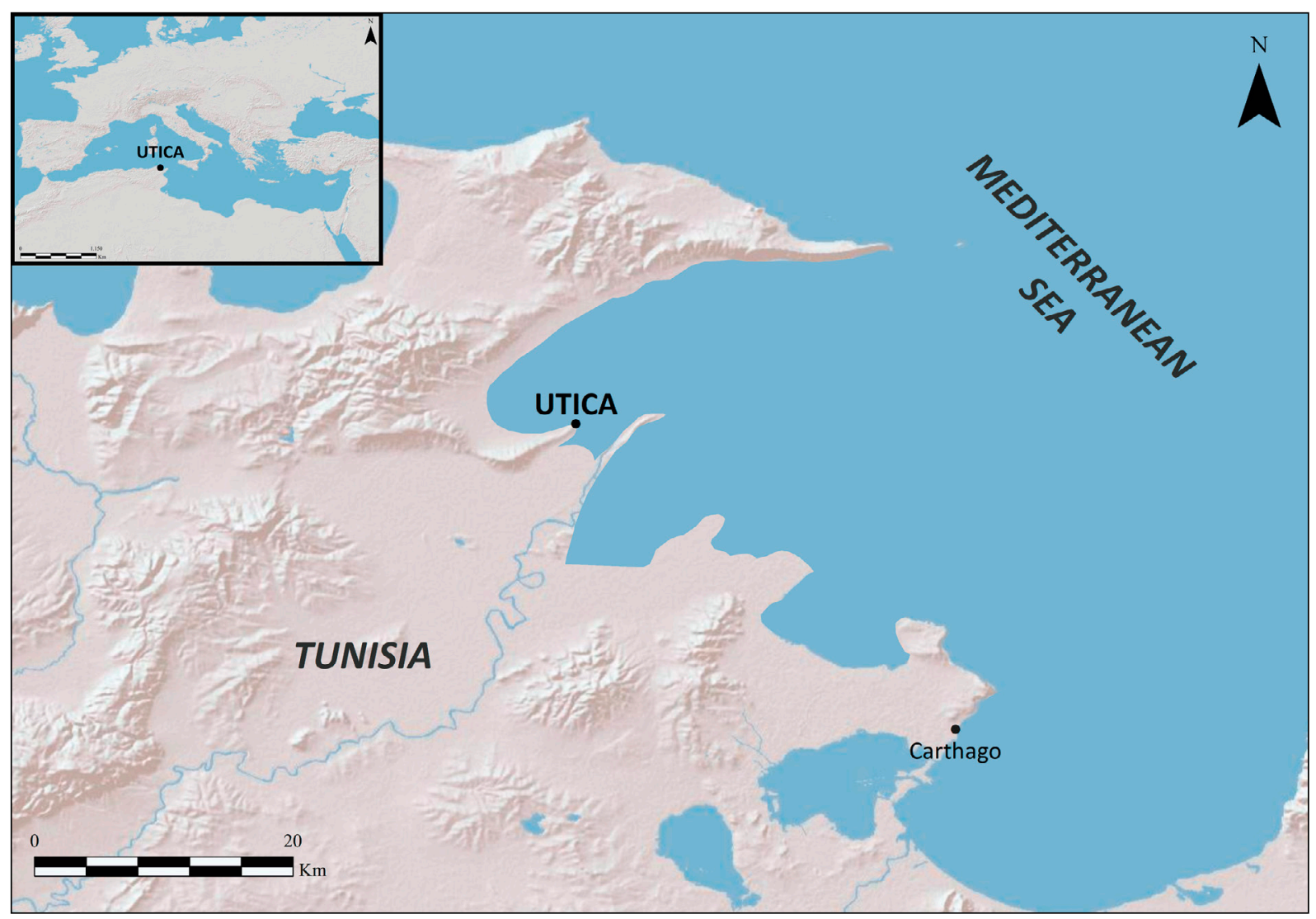

Figura 1. Situación de Utica y representación de la antigua bahía a partir de Pleuger et alii, 2019

Figure 1. Location of Utica and depiction of the ancient bay of Utica using data from Pleuger et al., 2019

En la Zona I, corte ro, se ha descubierto un área industrial y urbana fenicio-púnica ocupada desde el siglo viır a. C. hasta época imperial, conservada dentro de una insula romana (Ben Jerbania et alii, 2020). $\mathrm{Al}$ oeste del área urbana se han documentado en los cortes II, I2 y I5 los restos de dos edificios monumentales superpuestos, identificados como templos, de los que el más antiguo dataría de la segunda mitad del siglo vir a. C., mientras que el más reciente, construido a mediados del siglo iv a. C., presenta un mejor estado de conservación (López Castro et alii, 20I6c; Ferrer et alii, 2020; Ben Jerbania et alii, 202I).

\section{Objetivos de la campaña de excavación de 2016 y metodología empleada}

La campaña de excavación de 2016 se efectuó entre el 3 de mayo y el 5 de junio de ese año. Los principales objetivos consistían en continuar la excavación en extensión del área urbana descubierta en el corte io de la
Zona I, completando la excavación del sector 21 y extendiendo el corte ro por el este en el nuevo sector 22, a fin de exhumar las construcciones más occidentales registradas en la prospección geofísica de 2010 y precisar su datación. Por su parte, en el área oriental de la Zona I se preveía completar la delimitación y la excavación estratigráfica de los templos localizados en los cortes II, I2 y I5, mediante la ampliación la superficie de excavación en dirección norte en el corte II. En la Zona II el objetivo principal consistía en ampliar en planta el edificio de la fase del siglo IX a. C. localizado en el corte 2I, continuando la excavación en dirección oeste del muro fenicio que delimitaba el edificio por su lado norte. Asimismo, se preveía ampliar el corte 2I hacia el norte al objeto de delimitar una fosa romana situada en esa dirección, para comprobar si existían en su límite septentrional estructuras fenicias que se relacionasen con las ya documentadas.

Por último, se efectuó una prospección geofísica con radar de subsuelo (GPR) en diferentes sectores del borde norte de la Zona II del proyecto 


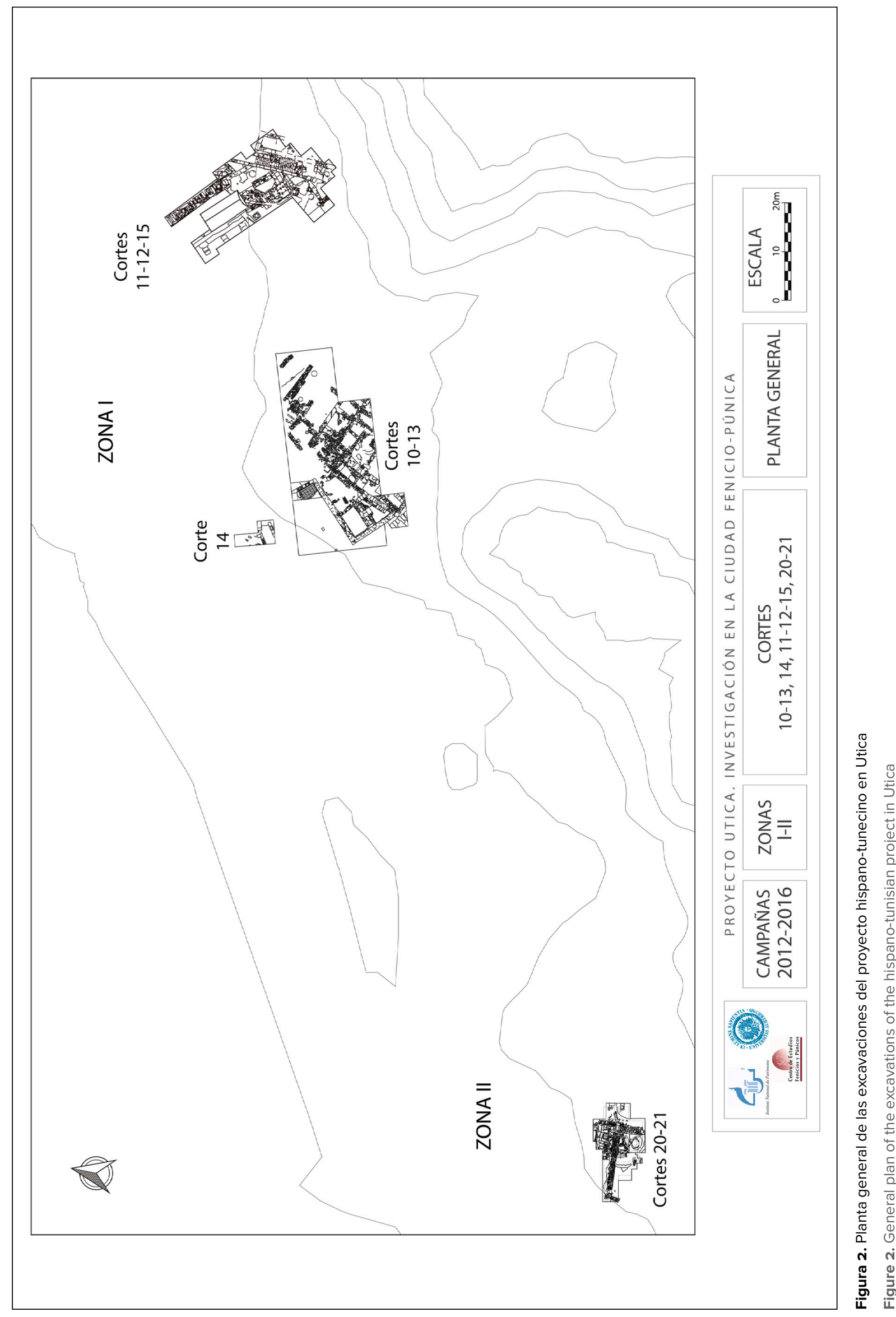


tunecino-hispano, con el objetivo de localizar estructuras antiguas en el límite de la antigua línea costera y definir los límites de la ciudad al noroeste. En la Zona I los objetivos de la prospección geofísica eran los de establecer la continuidad de las estructuras fenicio-púnicas entre los cortes Io y 15, así como de las escaleras monumentales de época romana altoimperial que rompen el templo fenicio del siglo iv a. C. La prospección fue realizada por los doctores José Antonio Peña Ruano y Teresa Teixidó Ullod, del Instituto Andaluz de Geofísica Aplicada de la Universidad de Granada, asistidos por Oier Ardanaz, de la empresa Investigación y Estudios de Geofísica Aplicada, S.L. El informe con los resultados de la prospección geofísica se anexan al final de este artículo.

En función de los objetivos señalados se excavó en área abierta en los tres cortes citados mediante el sistema de excavación por estratos naturales. En el proceso de excavación, además de artefactos cerámicos y metálicos, se recogieron la totalidad de los restos orgánicos arqueozoológicos y un amplio muestreo de los antracológicos, así como muestras arqueometalúrgicas y de restos constructivos. Todos los sedimentos primarios extraídos fueron cribados de forma sistemática, recogiéndose la totalidad de los restos recuperados por este procedimiento. Se recogieron muestras de sedimentos para la recuperación de restos orgánicos mediante flotación. El sistema de registro arqueológico consistió en un programa informatizado desarrollado por miembros del equipo del proyecto, denominado BARIA (Base de Archivos para el Registro Informatizado Arqueológico) en su versión I.2. El registro era informatizado durante el proceso de excavación mediante el programa cargado en tabletas, para proceder posteriormente en el laboratorio a la informatización del inventario de hallazgos en el mismo programa, añadiendo el registro planimétrico y una selección del registro fotográfico.

Como medidas de conservación adoptadas, al término de la campaña de excavación todas las estructuras en todos los cortes y sectores fueron $\mathrm{cu}^{-}$ biertas con geotextil para su protección. Los perfiles de los cortes fueron delimitados mediante plástico industrial. Sobre la capa de geotextil se dispusieron numerosos sacos rellenos de arena fina de albero, a fin de cubrir y proteger las zonas excavadas y permitir un desenterramiento rápido por medios manuales en la siguiente campaña. En otras ocasiones, sobre los sacos terreros se dispuso una capa de tierra. Todos los materiales de la campaña y una copia de toda la documentación de campo y de la base de datos, fueron depositados respectivamente en el Museo de Utica y en el Institut National du Patrimoine, así como el informe preliminar de la campaña.

\section{Resultados de la excavación en la Zona II}

\subsection{Las construcciones fenicias del corte 21}

La excavación del corte 2I se ha centrado en la campaña de 2016 en definir la continuación del muro fenicio 21099 localizado en campañas anteriores en dirección oeste, para tratar de ver en planta su prolongación y verificar si formaba ángulo con otro muro apreciable en superficie. Para ello se amplió el corte hacia el oeste alcanzando los $8 \mathrm{~m}$ de longitud total, hasta una palmera que impedía continuar la excavación. Inicialmente se realizó una ampliación al oeste de $3 \times 3,90 \mathrm{~m}$ rebajando el estrato superficial UE 2 II20 que contenía cerámicas modernas (figura 3).

Bajo esta capa se disponían tres unidades estratigráficas (figura 4): al este la UE 2II24, una capa gris compacta con manchas de carbón y ceniza, que contenía cerámicas fenicias, autóctonas libias y sardas que continúa la UE 2 IIoo documentada en la campaña de 2015 y que parece ser la misma unidad estratigráfica; al norte, la UE 2 II23 depositada al exterior del muro 21099, que contenía también materiales cerámicos antiguos y al este la UE 2II25, una capa muy dura, compacta y arcillosa, estéril, parcialmente cubierta por la UE 2II24. Ambas UUEE, 2II24 y 2II25 se depositaron sobre el suelo geológico estéril de greda arcillosa de color amarillento UE 20085 .

La UE 2 II24 cubría parcialmente el lado sur del muro 21099, que continuaba en dirección oeste durante $6 \mathrm{~m}$, con un ancho entre o,80 y i $\mathrm{m}$, y una sola o dos hiladas de piedras conservadas. A lo largo del 


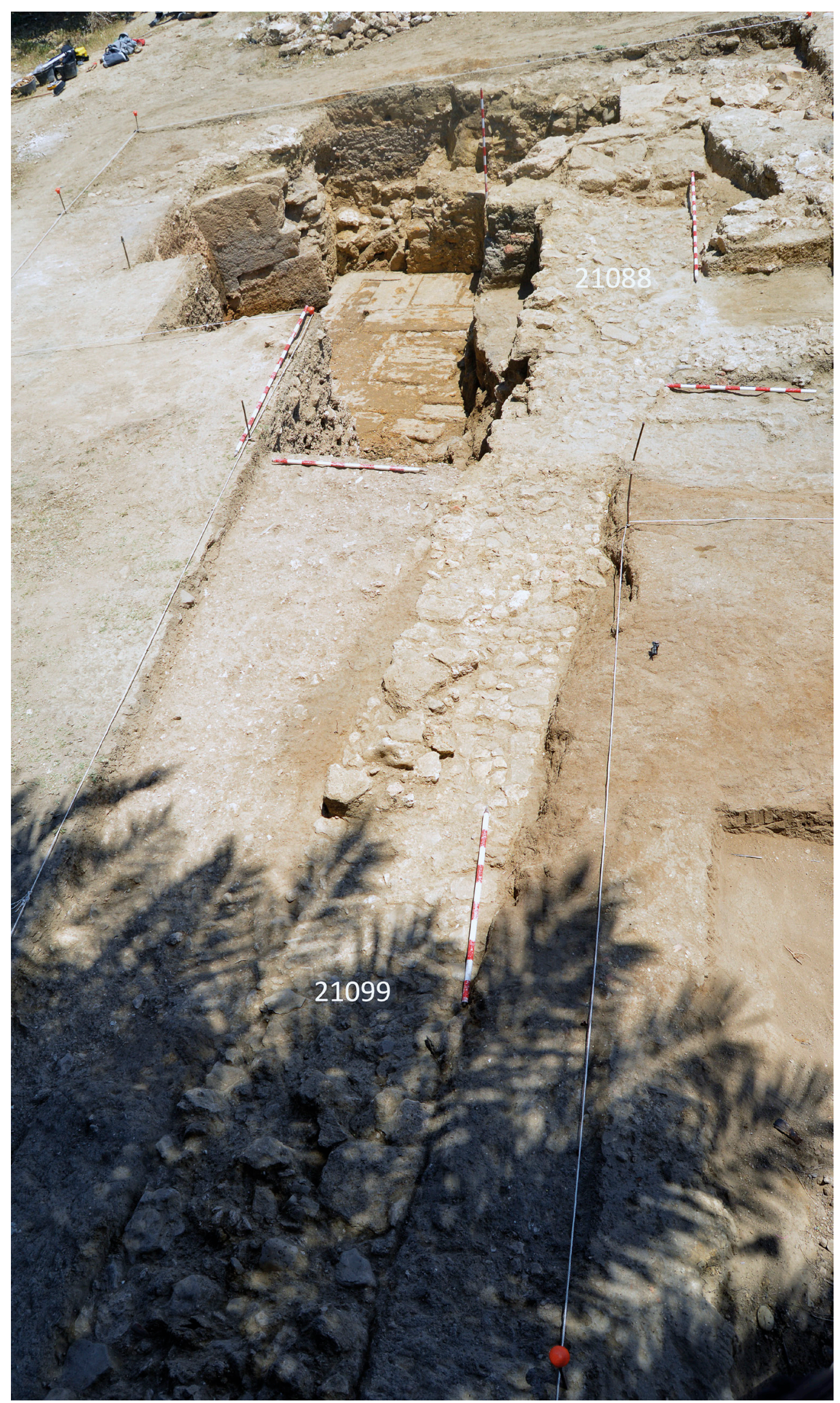

Figura 3. Corte 21, vista general del muro fenicio 21088-21099 y de las estructuras descubiertas en la campaña de 2016

Figure 3. Trench 21, general view of Phoenician Wall 21088-21099 and the structures discovered during 2016 season 


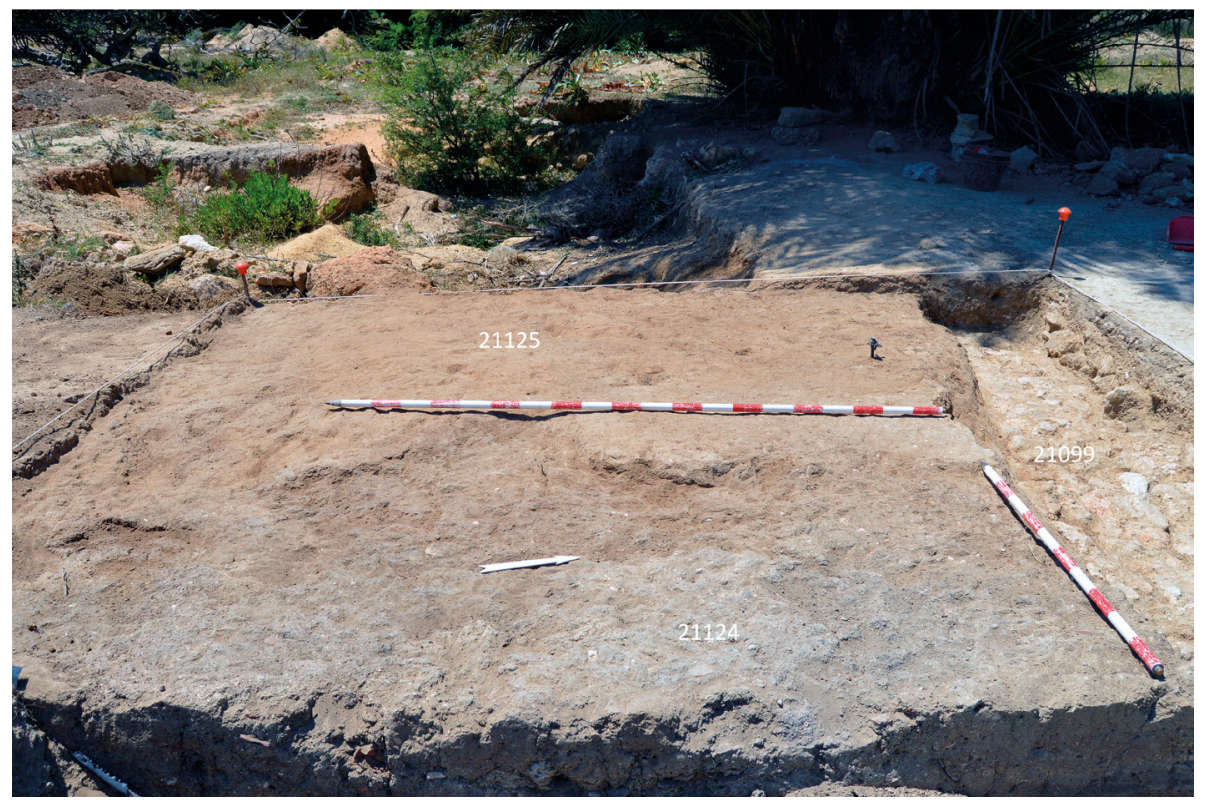

Figura 4. Corte 21, vista de la unidad estratigráfica 21124 en relación al muro 21099

Figure 4. Trench 21, view of stratigraphic unit 21124 in relation to wall 21099

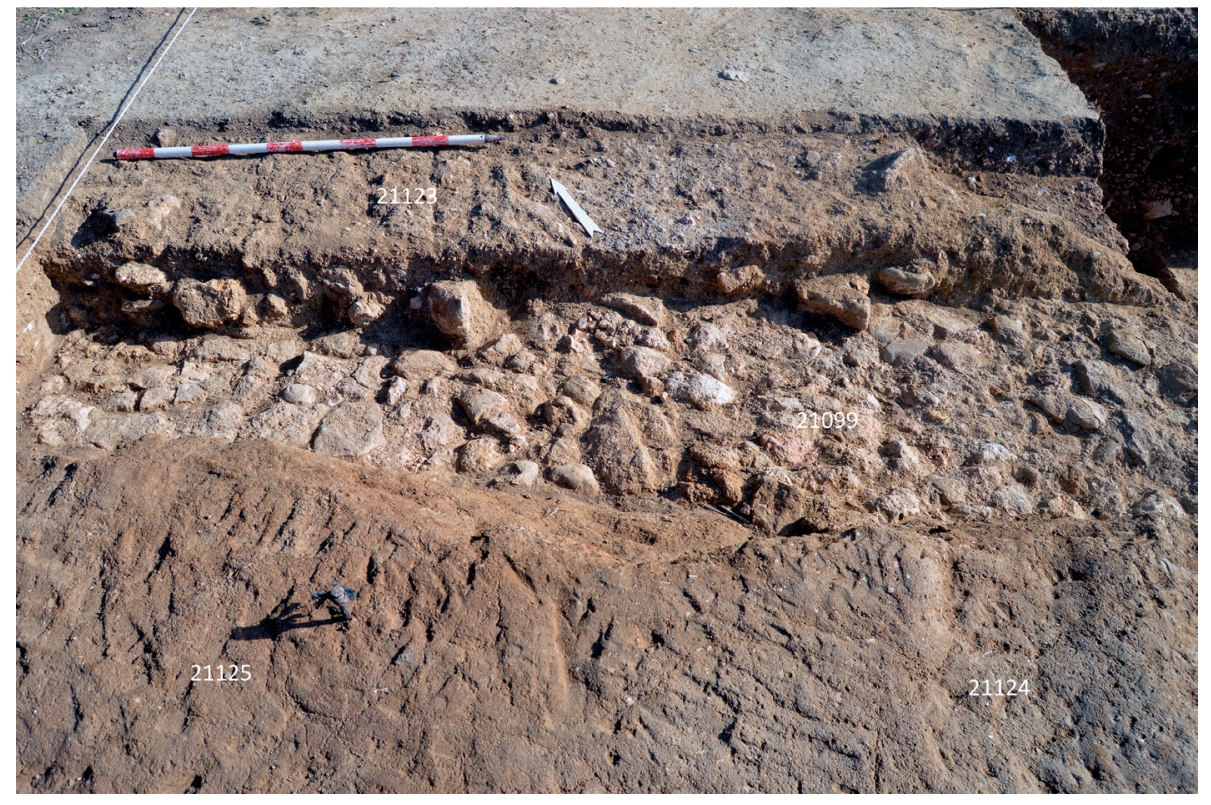

Figura 5. Corte 21, estratificación junto al muro 21099

Figure 5. Trench 21, stratification next to wall 21099

muro se sitúa en paralelo la fosa de expolio 21098 por su lado norte, que en ocasiones no llegó a afectar al sedimento de época fenicia adosado al exterior del muro fenicio 2IO99, la UE 2II23 ya mencionada, que se conserva en algunos tramos entre 0,20 y $0,60 \mathrm{~m}$ de anchura hasta la fosa romana (figura 5).

A partir del metro 4 de la ampliación oeste, a ambos lados del muro 21099, hasta el metro 8 nos encontramos con un estrato fenicio UE 2II33 que alcanza casi hasta la superficie, el cual contenía fragmentos de cerámica fenicia, sarda y griega geométrica.

En el metro 6 de la ampliación, el muro fenicio 21099 se interrumpe y parece haber un vano de entrada o espacio de circulación de $0,60 \mathrm{~m}$ de anchura. Asimismo, en el metro 7 comienza con seguridad un muro con dirección aproximadamente norte-sur, también fenicio, el muro 21139, que conserva al menos $2 \mathrm{~m}$ de su trazado, aunque al emplear 


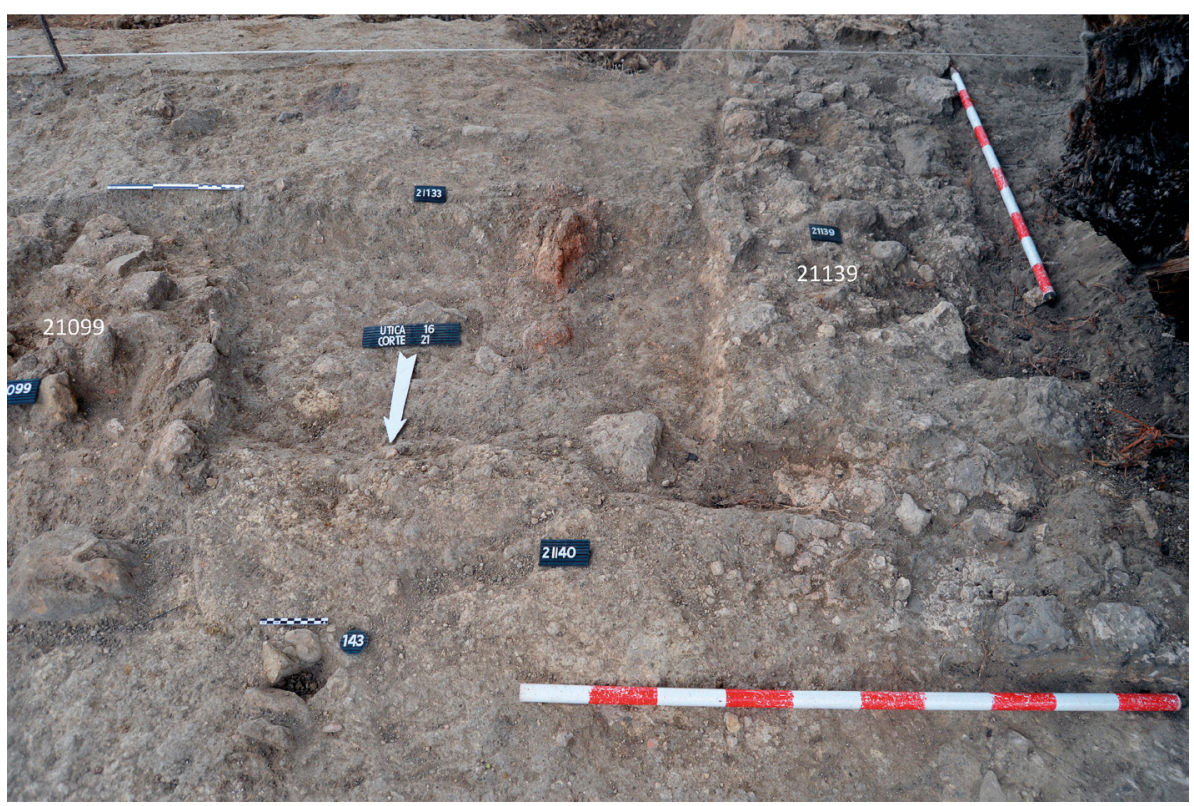

Figura 6. Corte 21, posible vano de entrada entre los muros 21099 y 21139 , con suelo 21140 y hoyo de poste 21143

Figure 6. Trench 21, Section 21, possible entrance opening between walls 21099 and 21139, with floor 21140 and post hole 21143

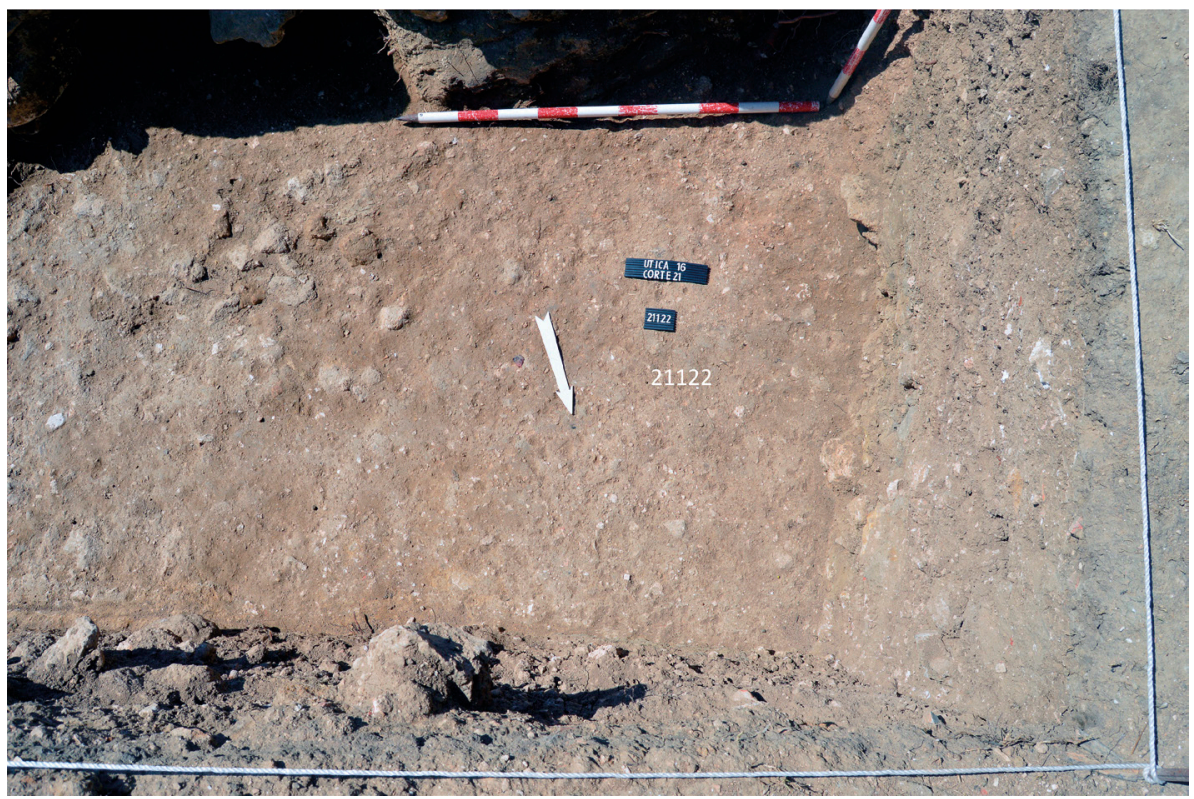

Figura 7. Corte 21, excavación de la unidad estratigráfica 21122 de la fosa de expolio

Figure 7. Trench 21, excavation of stratigraphic unit 21122 of the spoliation trench

piedras calcáreas, varias están parcialmente descompuestas. En principio debería ser un muro interior del edificio, adosado al muro exterior 21099, siendo además de menor grosor: $0,60 \mathrm{~m}$ frente a los 0,90-I,00 m de ancho del muro 21099. En el posible vano de entrada se detectó en su extremo norte un posible suelo 2II4O, compacto, con elementos calcáreos. En un extremo del vano se descubrió un pequeño hoyo de poste 2II43 y algunas escorias de hierro (figura 6).

Al norte del muro 21099 se llevaron a cabo varias ampliaciones sucesivas, de 3,50 × 5,90 $\mathrm{m}$ y de I,50 × I,80 en dirección oeste, con el objetivo de delimitar en esa dirección la fosa 21098 , que ocupaba toda la anchura del área septentrional del corte 2I, verificar su continuidad y vaciarla. Resultó ser una 
fosa de expolio de grandes dimensiones, que alcanzaba los 2,60 m de profundidad al oeste, cuya extensión total no pudo ser delimitada en la campaña. Contenía varios estratos de relleno superpuestos: el primero, la UE 2IO8I, en parte directamente bajo la superficie, estaba compuesto por tierra marrón suelta y contenía cerámicas romanas de época imperial, restos de elementos de decoración arquitectónica, estucos y fragmentos de pavimentos, así como algunas cerámicas medievales que datarían el expolio y posterior relleno. El segundo estrato, inferior al anterior, es la UE 2II22. Su textura es más compacta, de color rojizo, con el mismo contenido de materiales arqueológicos que el estrato anterior, mayoritariamente romanos y un fuerte buzamiento (figura 7).

Ambos estratos estaban separados por un estrato amarillento que contenía polvo de piedra arenisca descompuesta, la UE 2II34, probablemente resultado de la extracción y trabajo de los canteros que expoliaron los muros de sillares y bloques que se encontraban en la base de la fosa (figura 8). En efecto, al fondo de la fosa de expoliación 2IO8I y al norte del muro fenicio 21099 se encontró la base de un gran muro, el muro 2II32, con orientación noroeste-sureste, formado por sillares unidos con grapas de plomo sobre espigas de cola de milano (figuras 9 y ro).

En el lado noreste de la fosa su excavación ha revelado una serie de capas de relleno de características diferentes: al inicio nos encontramos con la UE 2108I que cubre la UE 2 III35 de color rojizo, depositada sobre la UE 2II38, de color marrón con áreas de color negro, ceniciento y textura friable, que contiene una bolsada de tierra roja arenosa. Bajo esta última capa se sitúa el estrato 2II4I de tierra marrón claro arcillosa con inclusiones de cal, carbón y fragmentos de estuco. Este estrato 2II4I cubre otro, la UE 2II44 que contenía en la parte superior una capa de adobes que no estaban en posición primaria, sino revueltos por la fosa, o también por la construcción del muro de sillares 2II30 situado al extremo este (figuras 8 y II).

En efecto, todos los estratos citados precedentemente (UUEE 2II35, 2II38, 2II4I, 2II44) están adosadas al muro de sillares de arenisca 2 II3O y contienen el mismo material cerámico de época romana, cuyo estudio nos ofrecerá dataciones más precisas. Por lo que respecta al muro 2II30, en el estado actual de la excavación presenta dos hiladas de sillares de arenisca que se apoyan sobre el muro 2II32, siendo aquel, por tanto, posterior a este. Su orientación es casi norte-sur y por consiguiente se desvía de la estructura $2 \mathrm{II}_{32}$ anteriormente descrita. Desgraciadamente, a causa de la subida del agua del nivel freático durante la excavación, ha sido imposible en esta campaña alcanzar la primera hilada del muro 2II3O, cuya base no pudo descubrirse (figuras 8 y Io) y cuya datación se desconoce.

Para la construcción de este gran muro 21132 fue necesario cimentarlo haciendo un gran rebaje en el sustrato geológico de greda, que afectó tangencialmente al muro 21099 y seguramente a los estratos depositados a su exterior, 2IIII, 2III5 y 2III7, cortándolos. Para la construcción del muro $2 \mathrm{II}_{32}$ el talud se revistió de muros de mampostería revocados con mortero de arcilla en sentido este-oeste disponiéndose el muro 2II28, así como el muro 2IO9I-2II27 consistente en un gran bloque de piedra en sentido norte-sur. Ambos muros forman un ángulo recto y se hicieron en un mismo momento (figura I2, figura I3).

Adosado al muro 2IO9I-2II27 y recubriendo el sustrato geológico se disponía el muro 2II29, hecho con piedras y arcilla, que continúa en dirección oeste haciendo ángulo con el muro 2II32. Sobre el muro 2I09I-2II27 se dispuso una capa de piedras y mortero sobre la que se asentaría otra fila de bloques de la misma estructura, del que se conserva uno descubierto en la campaña de 2015, que se numeró como muro 21087, por lo que parece que la estructura haría ángulo hacia el sur-suroeste, aunque el muro 21087, a mayor cota, habría sido expoliado sin dejar apenas traza, salvo un posible zócalo de piedras 2II29 que estarían en la base de la cimentación y que siguen la misma orientación que pudo tener el muro (figura I2, figura I4, figura 15). Este sistema constructivo fue el que se expolió en época medieval abriendo la fosa de expolio 21098. En posteriores campañas podrá precisarse la datación y funcionalidad de esta estructura de gran envergadura, el muro 2132 y construcciones anejas, que continúa en dirección oeste.

En el lado sur del corte 2r se aprecia cómo el muro 21099 es continuación del muro 21088 descubierto en campañas anteriores y forman la misma cara al sur (figura 15 ). Mientras que el primero conserva 


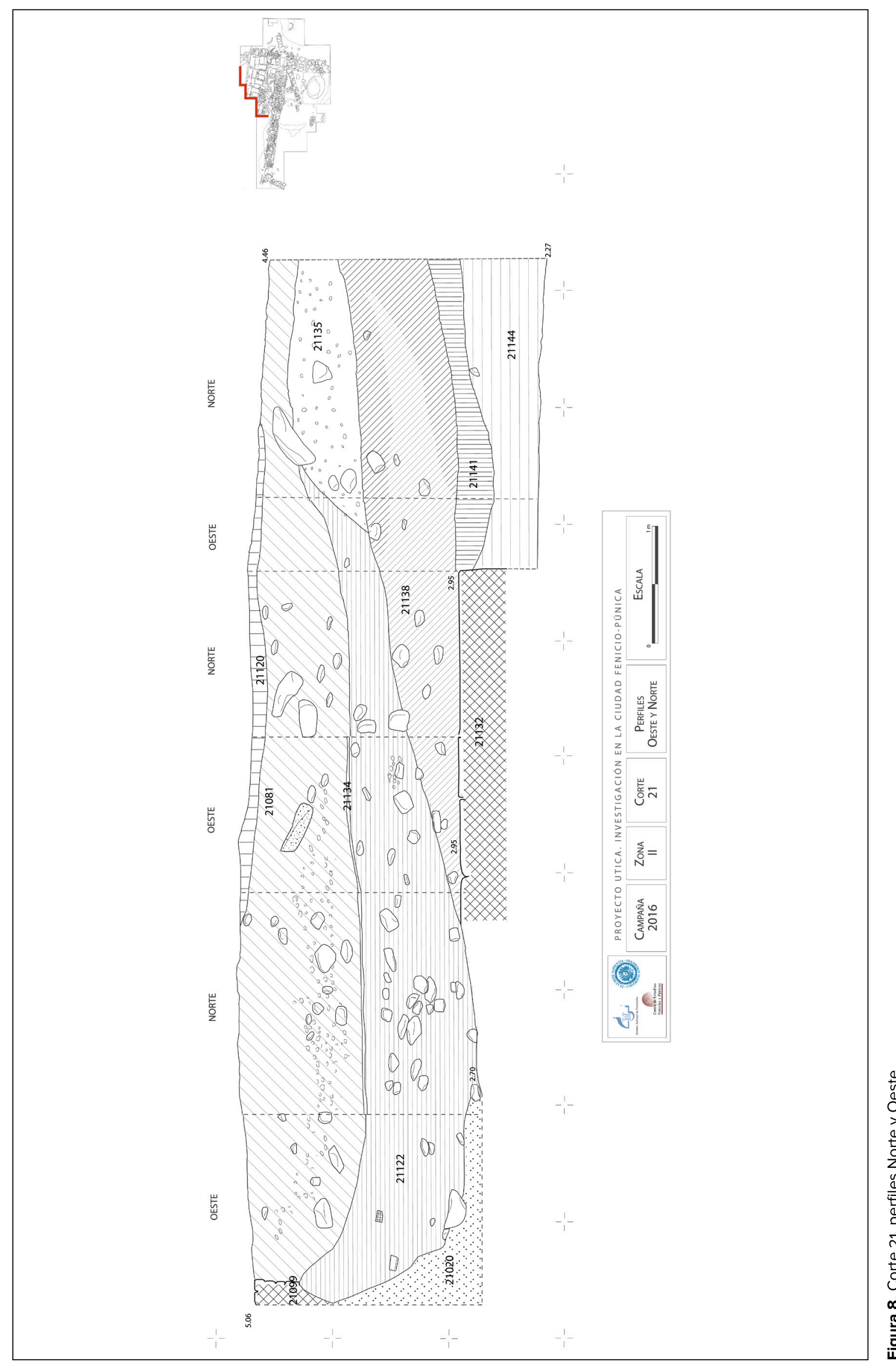




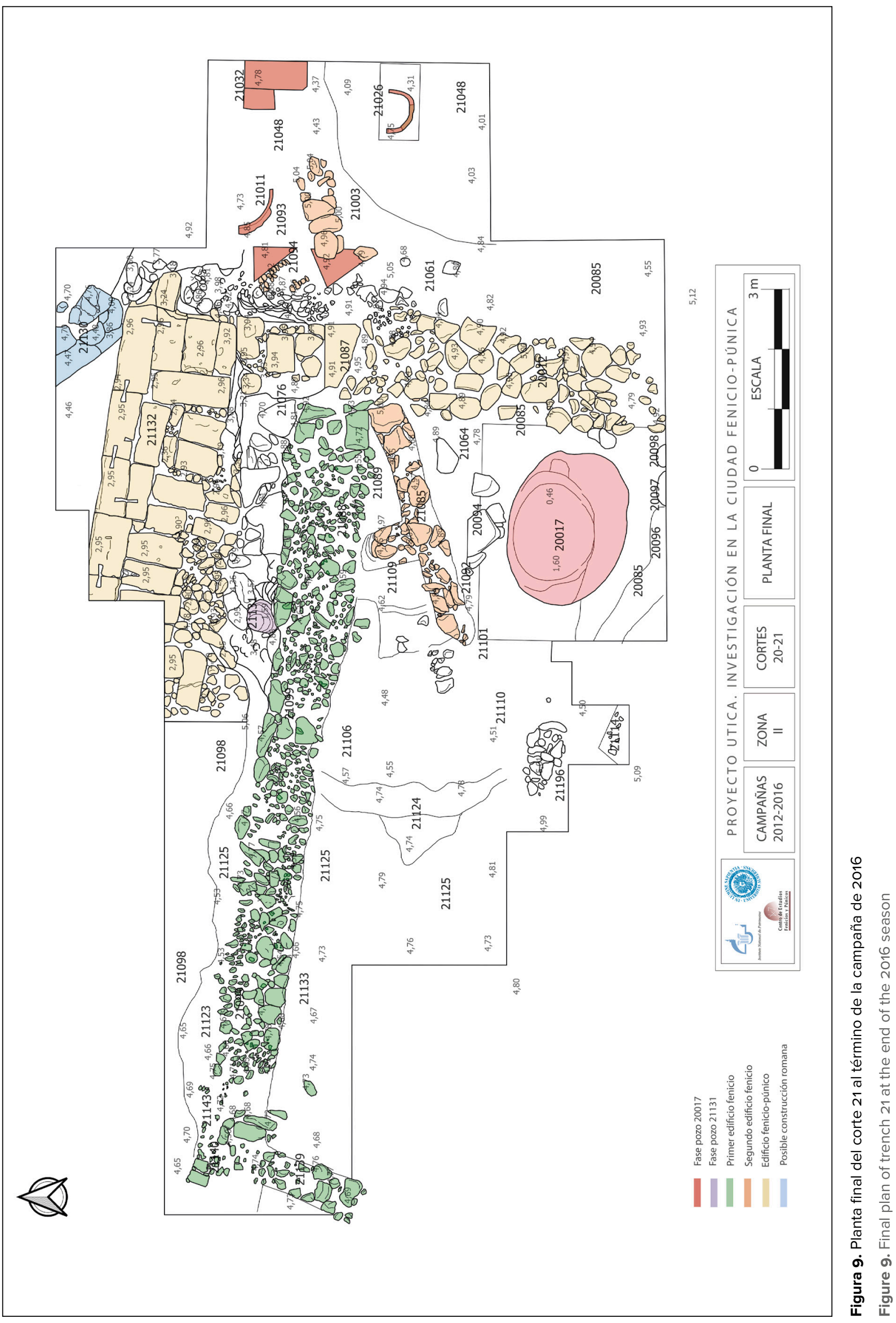




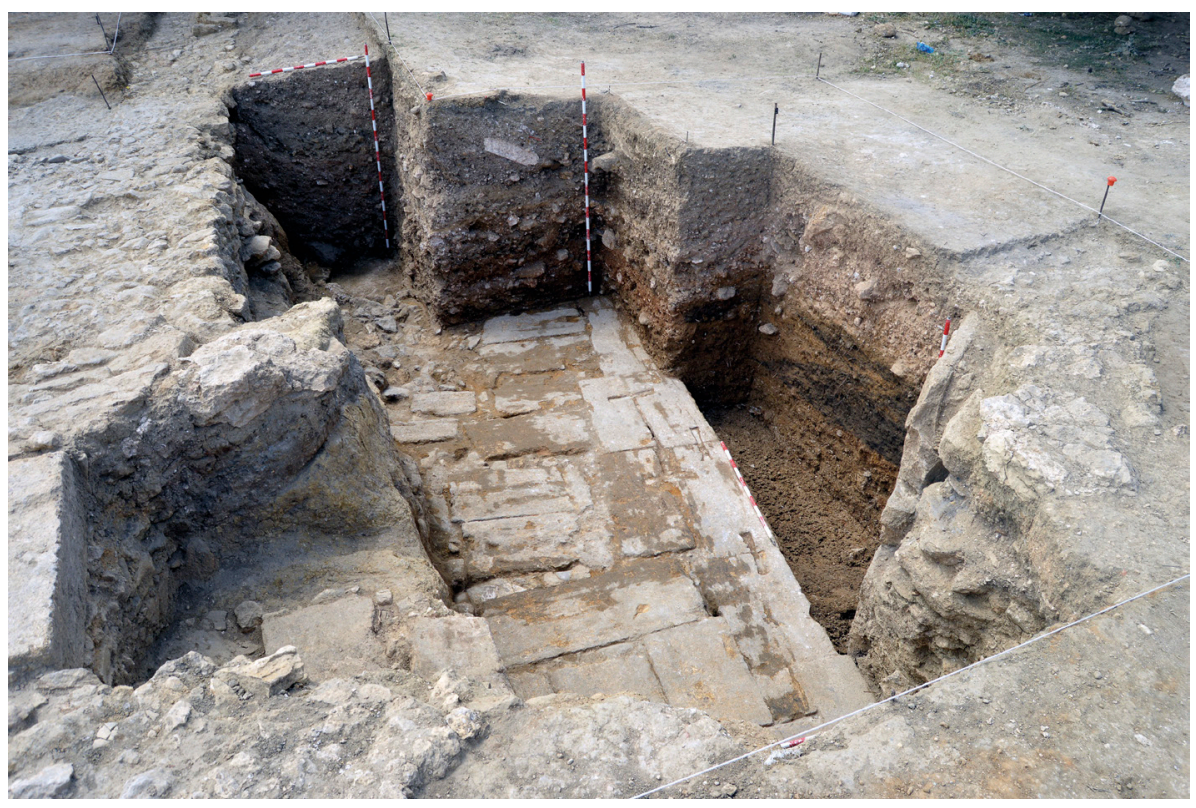

Figura 10. Corte 21, vista general desde el Este de la excavación de 2016

Figure 10. Trench 21, general view from the East of the 2016 excavation

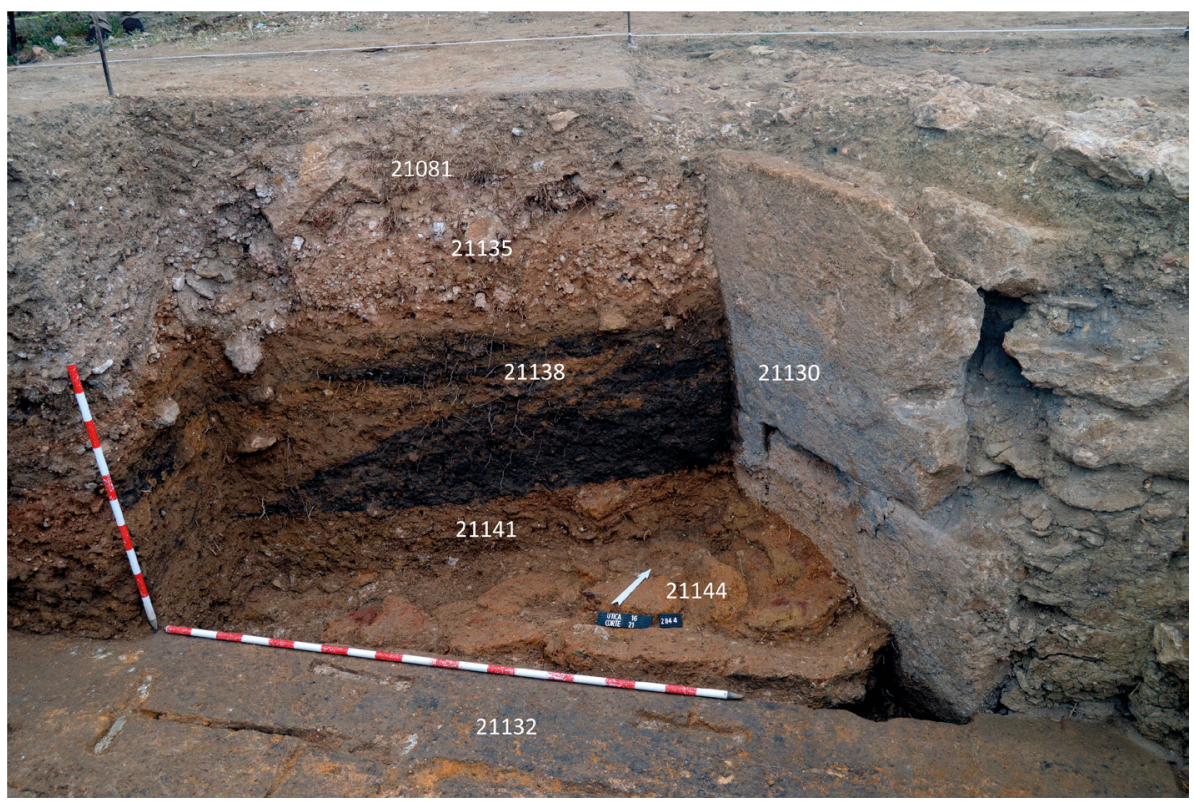

Figura 11. Corte 21, unidades estratigráficas del relleno de la fosa de expoliación

Figure 11. Trench 21, stratigraphic units of the spoliation pit backfill

apenas una sola hilada de piedras, el segundo dispone varias por la diferencia de cota del suelo geológico como se aprecia en el lado norte de ambos muros (figuras 5 y i6). En este lado, bajo el muro 21099, tras retirar el relleno rojizo UE 2 II22 de la fosa de expoliación que ocupa la parte norte del corte 2I, apareció la estructura vertical 2II3I, probablemente un pozo, pues está excavado en el sustrato geológico y formado por piedras dispuestas de forma circular.
En la parte superior las piedras aparentan formar una especie de conducción o canal de sección cuadrangular. En todo caso, el pozo fue cubierto y amortizado por el muro fenicio 21088-21099 (figuras I6 y 17), por lo que su cronología relativa lo hace más antiguo que el muro que lo ciega. Bajo la estructura del pozo y junto al muro de sillares 2 II 32 se descubrió una concentración de piedras de diferentes tamaños ligadas por un mortero de arcilla, la estructura 2II37, que 

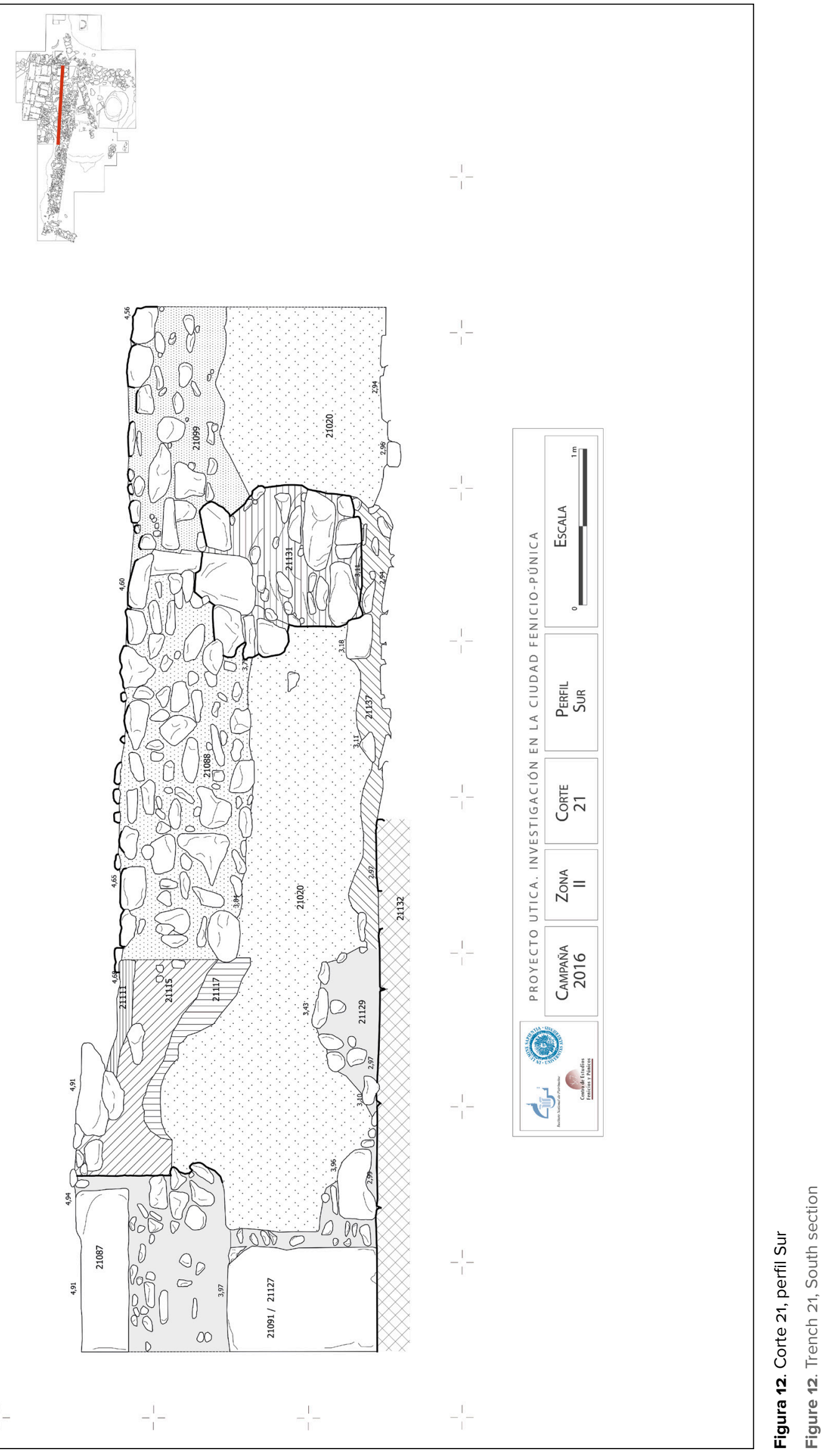


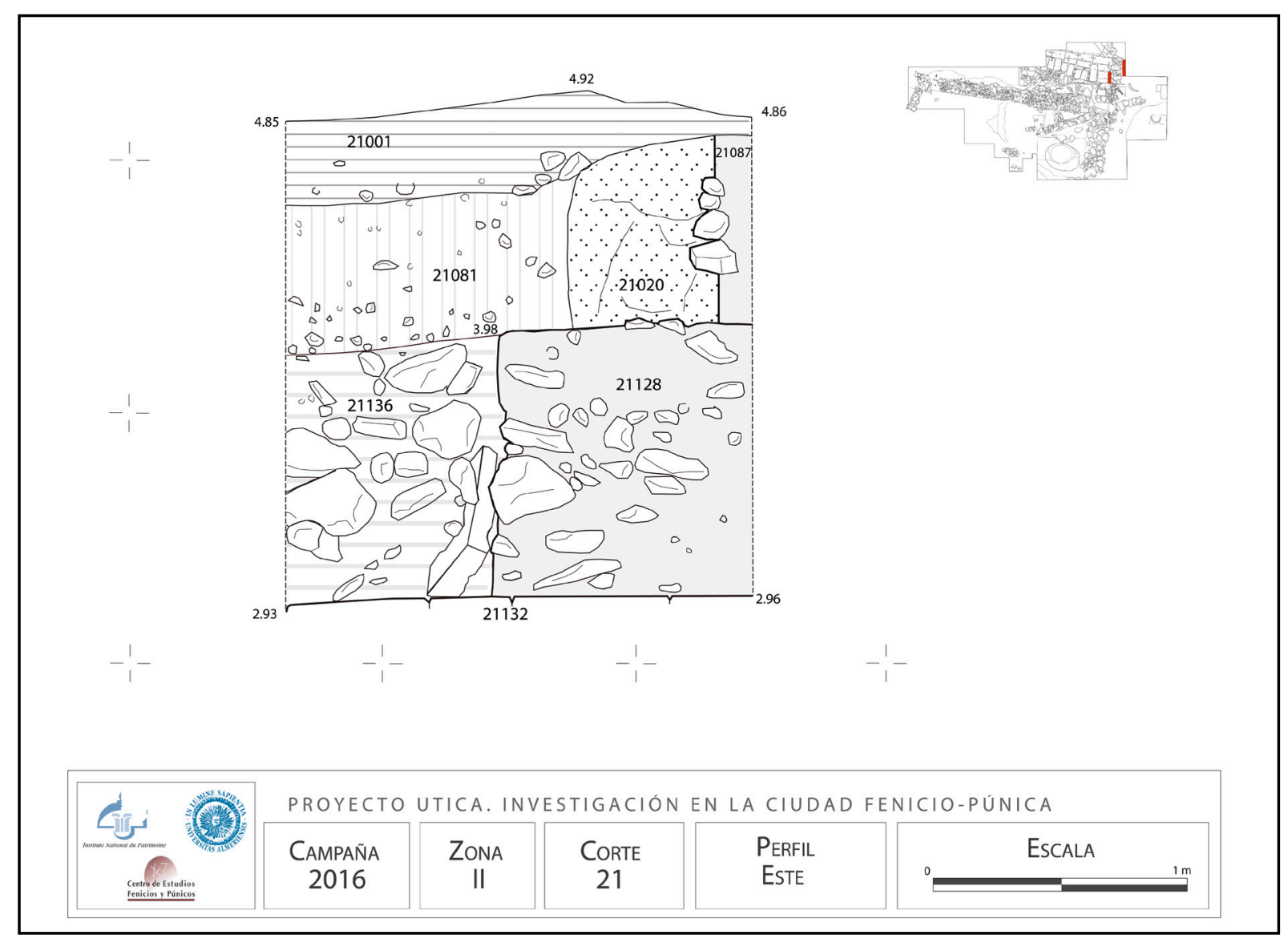

Figura 13. Corte 21, perfil Este

Figure 13. Trench 21, East section

parece estar en relación con el posible pozo 2II3I (figura r6).Probablemente el rebaje en el suelo geológico para la construcción del gran muro 2II32 afectó al pozo amortizado, dejándolo al descubierto parcialmente. Posteriormente fue cubierto por las hiladas desaparecidas del gran muro $2 \mathrm{II}_{32} \mathrm{y}$ tras su expolio, por el relleno de la fosa UUEE 2 II22 y 2108I.

Tras el expolio del muro 2II32, todo quedaría cubierto por el relleno de la fosa 2IO98. En el lado este de la fosa, sobre el muro 2 II 28 se adosa una concentración de piedras de diferentes tamaños, el derrumbe 2п36, que aparece bajo otro derrumbe 2Iı26, probablemente producidos a causa del expolio, y que se sitúan bajo la fosa 2108I (figura I4).

\subsection{La cronología de las construcciones fenicias}

Además del pozo 200I7, la estructura fenicia más antigua documentada en este sector de Utica (López
Castro et alii, 20I6b) las campañas de 2013, 20I4 y 2015 descubrieron diversas estructuras fenicias en el corte 2I consistentes en muros correspondientes a dos fases constructivas y estructuras de combustión como hornos domésticos. Los resultados de la campaña de excavación de 2016 permiten definir mejor la secuencia estratigráfica de la ocupación fenicia y la cronología de las diferentes estructuras, establecida también con algunas dataciones absolutas de ${ }^{14} \mathrm{C}$.

Las UUEE 2II24 y 2II33 excavadas esta campaña están depositadas sobre el muro 21088-21099 y las cerámicas que contenían contribuyen a datar esta construcción estableciendo un terminus ante quem. Hemos de tener en cuenta asimismo que la UE 2II24 es continuidad de la UE 2IIoo con la que se identifica, la cual se sitúa al interior de dicho muro. La UE 2II33 se sitúa en el ángulo interior definido por los muros 21088-21099 y el 2II39 con el que forma ángulo (figura 9) por lo que también se sitúa en el interior del edificio definido por ambos muros. 


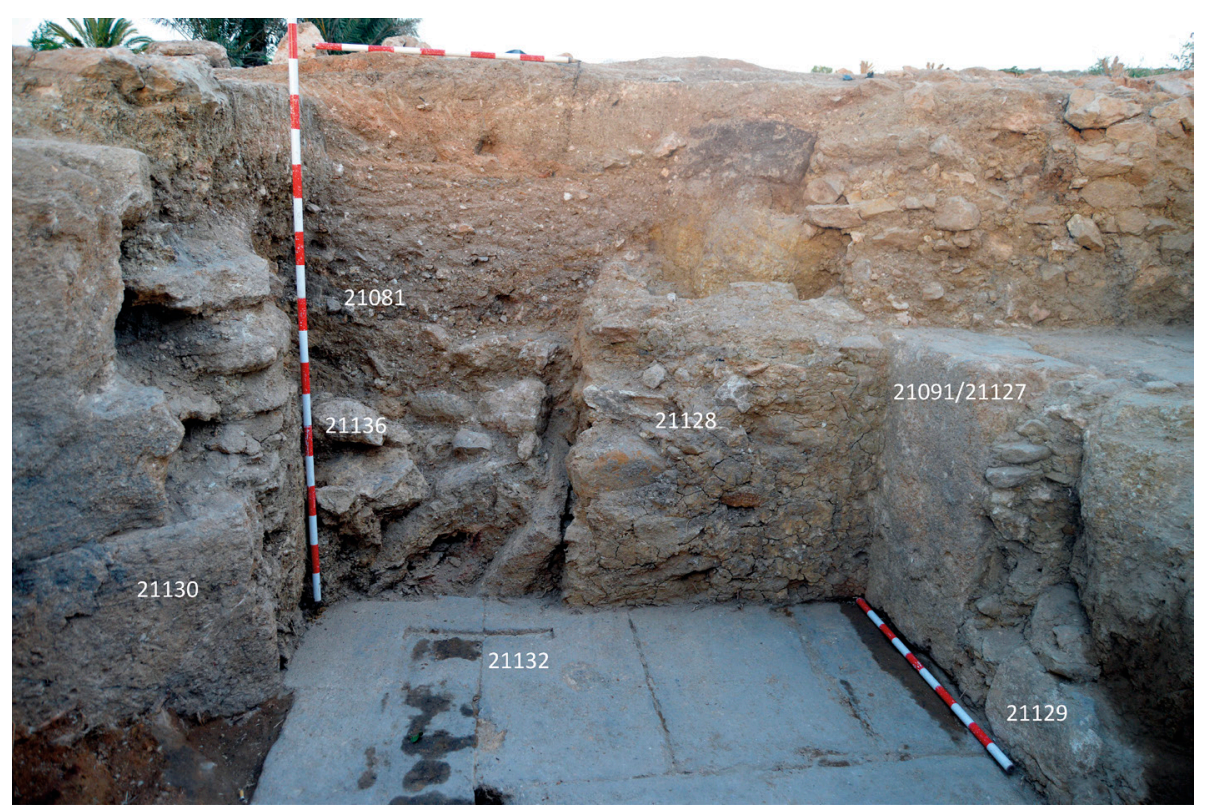

Figura 14. Corte 21, muros anejos al muro de sillares 21132 y muro 21130 apoyado sobre aquel Figure 14. Trench 21, walls adjoining ashlar wall 21132 and wall 21130 supported on Wall 21132

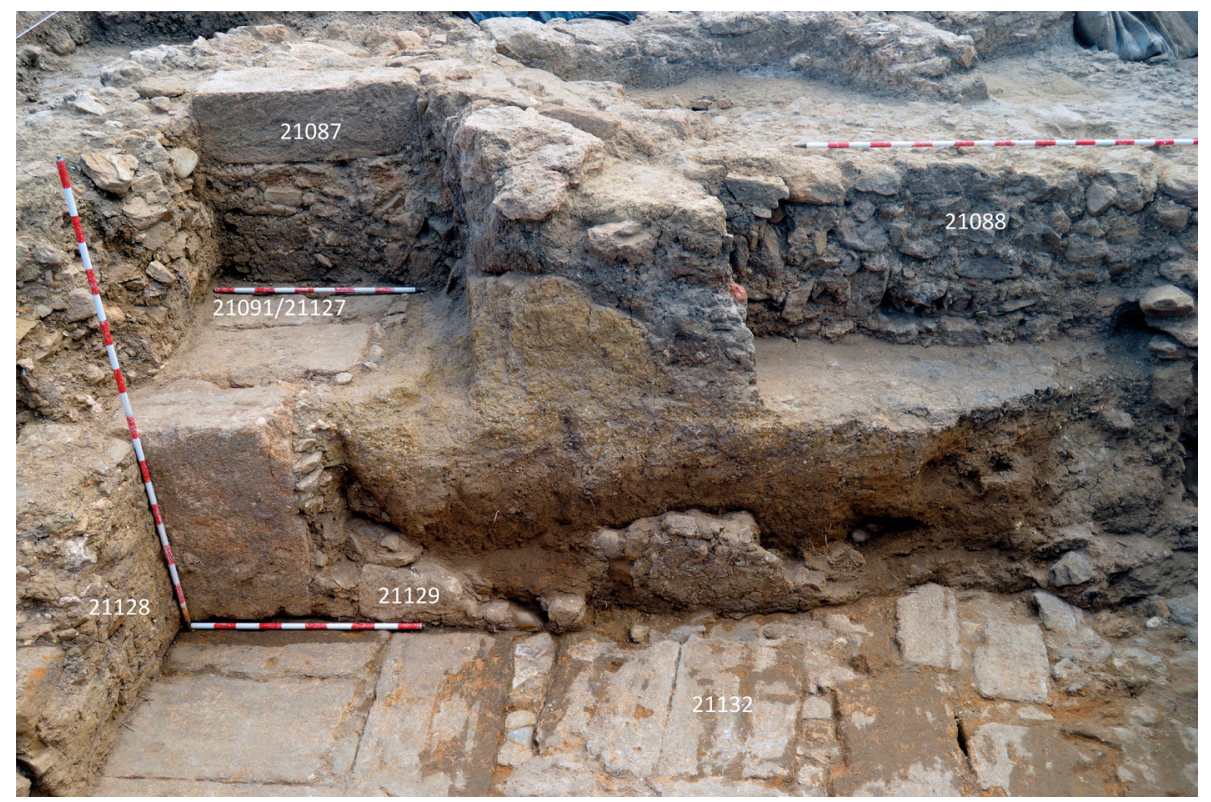

Figura 15. Corte 21. Muro fenicio 21088 y construcciones anejas al muro de sillares 21132 bajo la fosa de expoliación 21098

Figure 15. Trench 21. Phoenician Wall 21088 and constructions attached to the ashlar wall 21132 under the spoliation pit 21098

Entre las cerámicas más representativas de estos estratos tenemos algunos fragmentos de ánforas de inspiración oriental y producción sarda, denominadas de tipo Sant'Imbenia o «fenicio-sardas» (Ben Jerbania, 20I7: 192-I93), fabricadas a mano y también a torno, como un fragmento de borde e inicio del cuello de un ánfora sarda a torno (figura I8: 2I684-I), así como un fragmento de asa decorada con dos incisiones longitudinales (figura 15: 2I672-2) que recuerda otras asas con incisiones, si bien circulares, de este tipo de ánfora en Cartago (Niemeyer, 2007: 637-638, fig. 346).

Está bien representada la cerámica a mano autóctona con formas de cocina como la olla, de la que tenemos fragmentos de un borde (figura I8: 21676-6) 


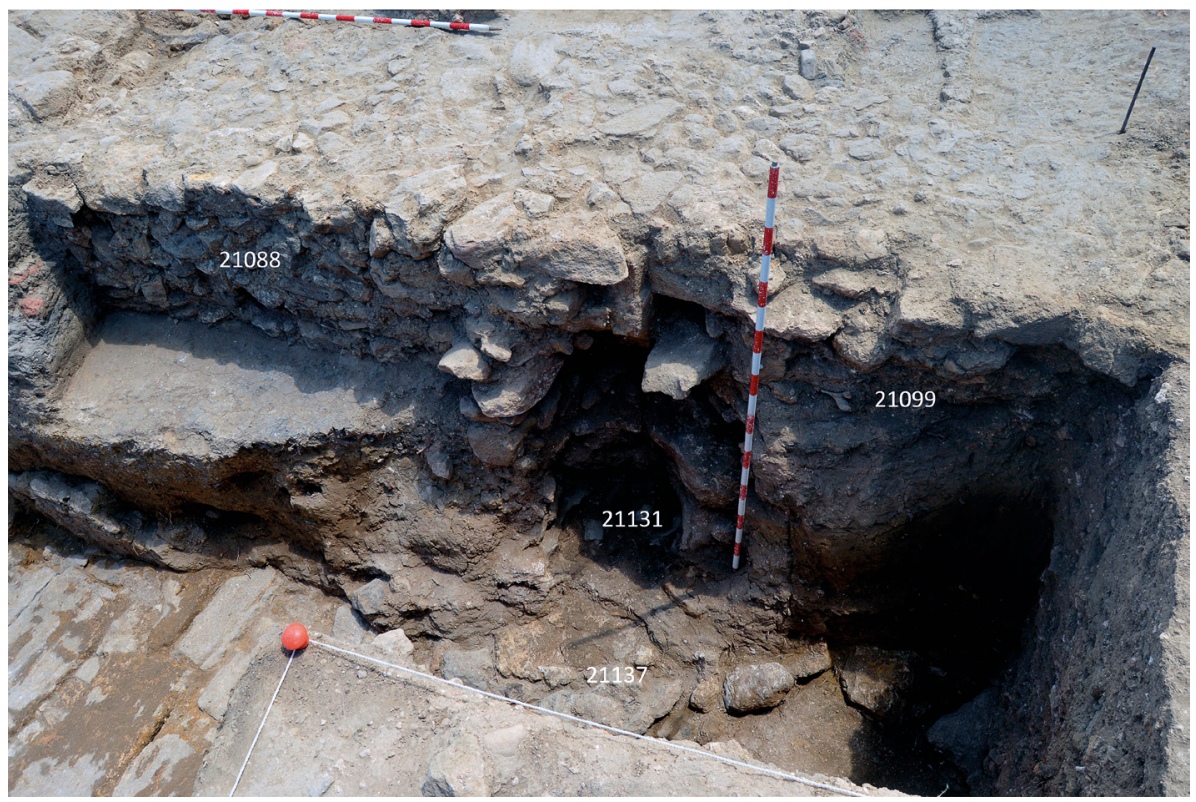

Figura 16. Corte 21, muro 21088-21099, cubriendo el pozo 21131 y la estructura 21137

Figure 16. Trench 21, Wall 21088-21099 covering well 21131 and structure 21137

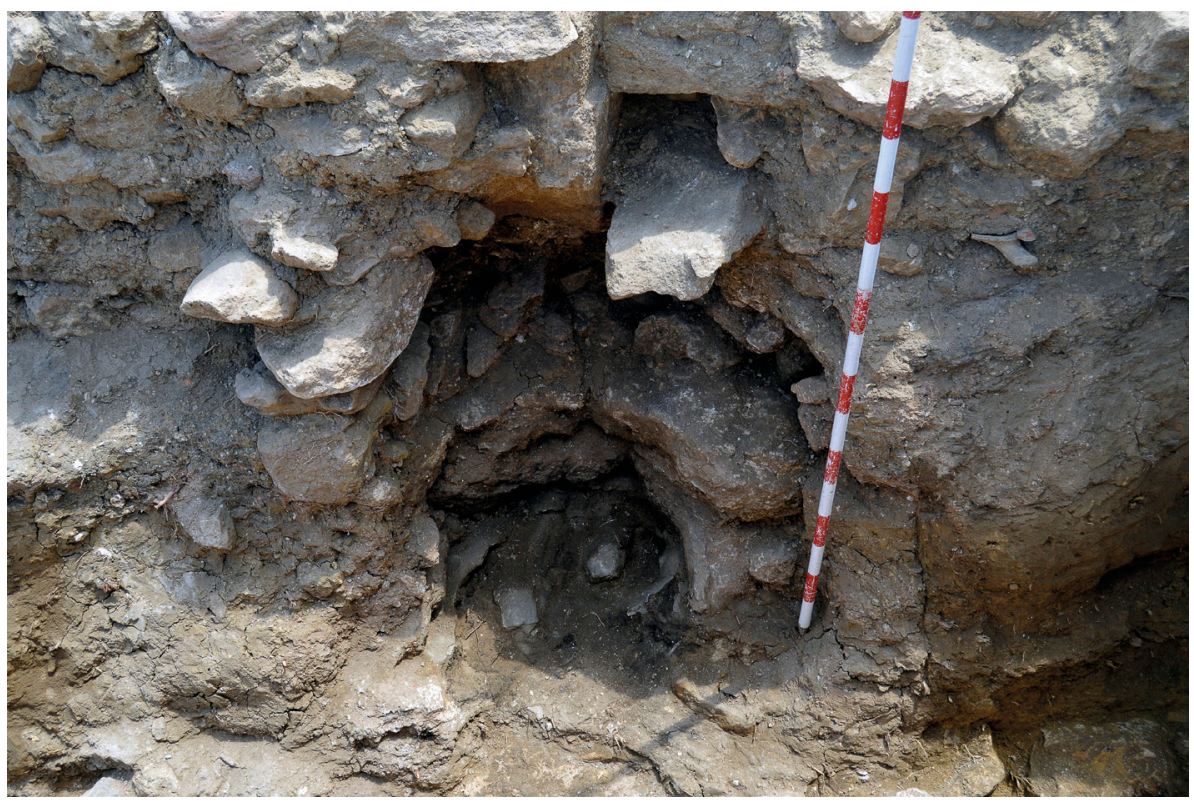

Figura 17. Corte 21, pozo 21131 bajo el muro 21088-21099

Figure 17. Trench 21, the well 21131 under the wall 21088-21099

y un fondo plano (figura 18: 21676-25) similares a los que encontramos en la fase Númida Antiguo i de Althiburos (Ramon y Maraoui Telmini, 201r: 389, I5 y 20) fechada por ${ }^{14} \mathrm{C}$ entre ro20-81o cal AC (Sanmartí et alii, 20I2: 3I). En el repertorio está presente un tajine de paredes oblicuas que recuerda los modelos atestiguados en Althiburos desde el periodo Númida Antiguo (figura I8: 21676-23) (Sanmartí, Ramon y Maraoui Telmini, 20I6: 90, fig. 3.II).
También encontramos platos a mano con superficie alisada y sin un borde definido. El primero (figura I8: 21676-28), con un perfil ligeramente convexo y labio redondeado, se asemeja morfológicamente a los platos a torno del tipo ro de Tiro (Bikai, 1978: pl. XCI); esta forma también está atestiguada en yacimientos autóctonos y fenicios de la península ibérica, como en Morro Mezquitilla (Puch Monge, 20I7, I72-I75, fig. 3, tipo 4.2b). E1 segundo 


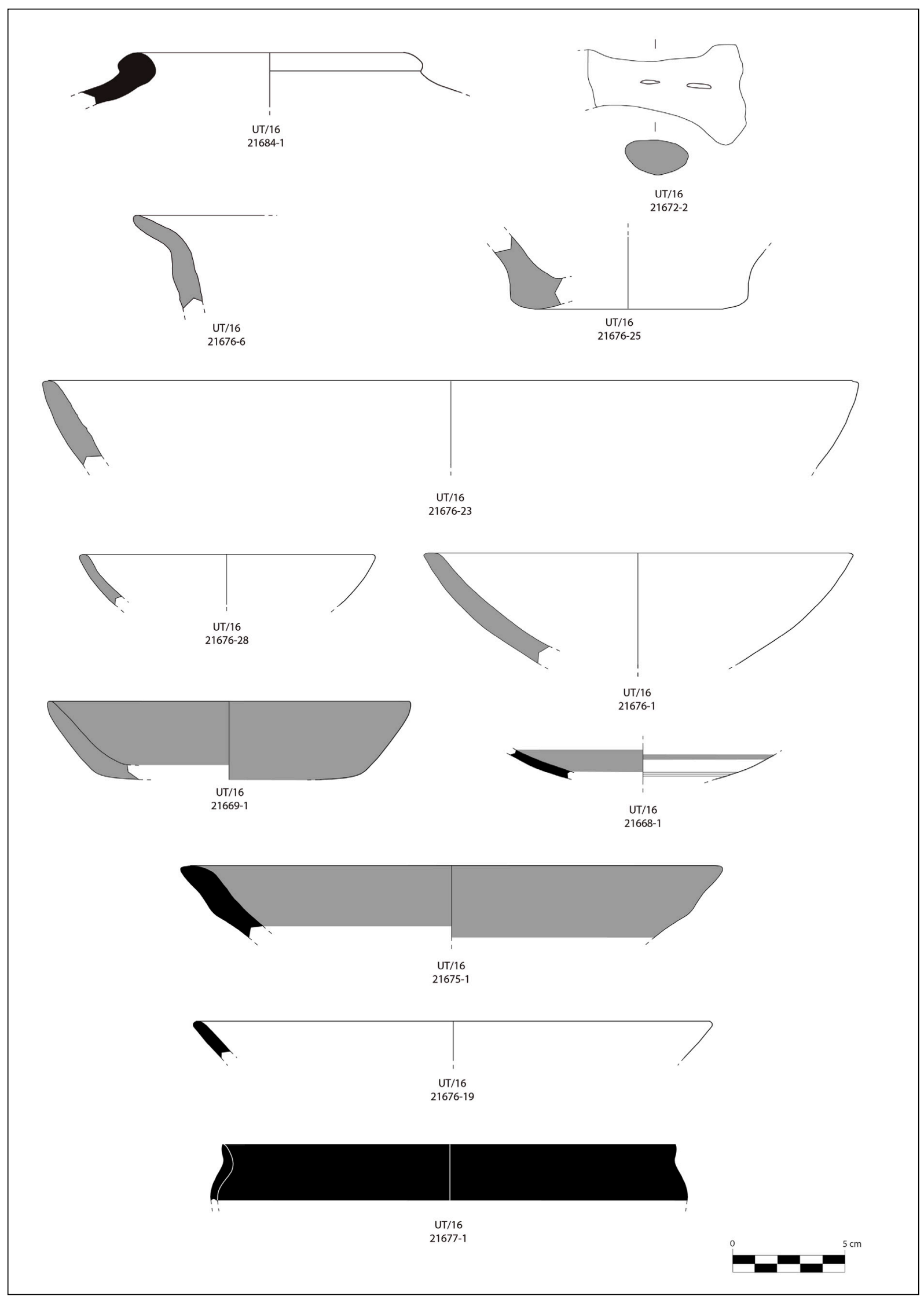

Figura 18. Cerámicas de las unidades estratigráficas 21124 y 21133

Figure 18. Pottery from stratigraphic units 21124 and 21133 
ejemplar, con el mismo perfil (figura 18: 21676-I), tiene unas dimensiones medias y labio superior aplanado y se acerca a algunos cuencos de superficie lisa de la fase Númida Antiguo i de Althiburos (Ramon y Maraoui Telmini, 20II,: 388, 6.2) y también con mayor diámetro en el Númida Antiguo 2 (Ramon y Maraui Telmini, 20II: 385, 10, 26; 386, 22), fechada también por cronología radiocarbónica a finales del siglo Ix cal AC (Sanmartí et alii, 20I2: 33).

Por último, destaca un plato a mano con fondo plano, perfil abierto y paredes rectas que incorpora engobe rojo interior y exterior (figura I8: 21669-I), del que encontramos posibles referentes en la fase Númida Antiguo I de Althiburos en fragmentos de borde y fondo quizá pertenecientes a esta misma o parecida forma (Ramon y Maraoui Telmini, 20Ir: 388, 3.2 y 3.4). No obstante, existen paralelos más estrechos en este mismo yacimiento númida tunecino de Althiburos (Sanmartí, Ramon y Maraoui Telmini, 2or6: 93, fig. 3.20.), si bien estos platos engobados en rojo proceden todos de los niveles del periodo Númida Reciente. No es extraño, según los autores de la excavación en este yacimiento, que sean más antiguos. Así pues, parece que el ejemplar de Utica fuera el antecedente tipológico de estos platos de Althiburos.

Entre las cerámicas fenicias contamos con cerámicas de mesa como un fragmento de copa plana de fine ware (figura I8: 21668-I) con engobe solo al interior, característicos de las copas de inicios del Hierro Tardío en Tiro Al-Bass (Núñez, 20ro: 6I) y bandas de reserva al exterior, así como platos con engobe rojo (figura 18: 21675-I) o sin engobe (figura I8: 21676-I9). El plato con engobe rojo es de gran tamaño y similar a los platos «misceláneos» de Tiro de mediano tamaño y paredes gruesas de los estratos IX-VIII y IV (Bikai, I978: pl. XIX, no 25-26, pl. XV, no I6-I7) y a platos de engobe rojo de Tell Habu Hawam (Herrera y Gómez, 2004: 245-246, lám. XVIII, I68 y I69). El plato sin engobe, aunque es un pequeño fragmento, podría adscribirse al tipo 8 de los platos de Tiro (Bikai, I978: pl. XCI; 2003: pl. I, 4-5 y 7-8). Finalmente están presentes importaciones de cerámica griega geométrica como un fragmento de skyphos monocromo (figura I8: 2I677-I) de la UE 2 III33 de tamaño mediano que pertenecería al tipo $\mathrm{Sk}_{3}$ de Eretria. Los skyphoi monocromos son abundantes durante el Geométrico Medio II e inicios del Geométrico Reciente I (Verdan et alii, 2008: 74-75, 223).

Este tipo de producciones cerámicas fenicias, libias autóctonas, sardas y griegas geométricas es ya conocido en Utica y tiene sus precedentes y referentes inmediatos en las recientes excavaciones tunecinas, franco-tunecinas e hispano-tunecinas en el yacimiento (Ben Jerbania y Redissi, 2013; Ben Jerbania, 2013, 2020; López Castro et alii, 202ob) donde están bien representadas.

El conjunto de las UUEE 2 II24 y $2 \mathrm{II}_{3} 3$ es cronológicamente homogéneo y similar al que conocemos en la UE 2IIoo del corte 2I excavada con anterioridad: ánforas sardas a mano, platos y jarros fenicios con y sin engobe rojo, así como vasos vilanovianos importados (López Castro et alii, 2020c: I322, fig. 5: a-j). El estrato 2IIOO nos proporciona también una datación absoluta efectuada en 2015 que marcaría un límite antes del cual se construyó el edificio: $2989 \pm 58 \mathrm{BP}$ 915 [862] 735 cal AC (Beta-455029-AMS). Como ya indicábamos, al exterior del muro 21088-21099 hacia el norte, el rebaje para su construcción cortó una serie de estratos superpuestos depositados al exterior del muro 2I088-21099 y apoyados en él: las unidades estratigráficas 2IIII, 2III5 y 2III7 (figura I2). De la más reciente, UE 2III5 y de la más antigua, UE 2III7 se han obtenido también en 2015 dos dataciones absolutas sobre semillas, respectivamente Beta-490782 $2700 \pm 30 \mathrm{BP} 905$ [830] $806 \mathrm{cal} \mathrm{AC} \mathrm{y} \mathrm{Beta-490784}$ $2770 \pm 30 \mathrm{BP} 997$ [904] $839 \mathrm{cal} \mathrm{AC}$, que establecen el periodo de funcionamiento del edificio y su desmantelamiento entre, al menos 997 [904] 839 AC y 905 [830] 806 AC. Este edificio es, por tanto, más reciente que el pozo 200I7 de acuerdo con las dataciones absolutas conocidas (López Castro et alii, 2016b). El pozo 2103I descubierto en la campaña de 2016 sería más antiguo que el edificio definido por el muro 21088-21099, pues este lo ciega, aunque no podemos precisar más sobre su datación al no haber sido excavado.

La campaña de 2016 ha hecho posible clarificar y comprender mejor los restos constructivos fenicios situados al este del corte 2I, muy superficiales y en mal estado de preservación debido a las fosas de expolio y a la intensa actividad antrópica en la zona. Sobre las hiladas restantes del muro 2I088-21099 una vez amortizado se depositaron dos unidades estratigráficas sobre 
las que se asentó un muro fenicio más reciente, el muro 21085 que sigue una orientación $75^{\circ}$ suroeste-noreste, diferente a la del edificio más antiguo (figura 9). En su recorrido en dirección noreste fue cortado por las piedras de cimentación cronológicamente posteriores del muro 20012 que continúa con la misma orientación al muro 2109I-2II27-2IO87. El muro 21085 continúa haciendo un ángulo formado por grandes adobes, 21082 y 21093, entre los cuales se dispone una superficie pavimentada con pequeñas piedras al interior de una estancia destruida por el muro 200I2-21087 (figura 9). El muro de adobes 21082 continuaba al este con el muro 21003 de piedra, que mantenía la misma orientación.

Así pues, los muros 21085-21082, 21093 y 21003 delimitan un espacio compartimentado dentro del cual se dispuso el horno doméstico de adobe 2IoIr, que conservaba solo la mitad. Al sureste del muro 21003 se localizaron los restos de otro horno doméstico, 21026, probablemente dentro de otro posible espacio compartimentado (figura 9). Al sur del muro de adobe 21082 se descubrió un hoyo de poste, 2Ior8, relacionado posiblemente con esta habitación. Próximo al horno 2Iorr se disponía un suelo o nivel de circulación, la UE 2IOI2 donde se depositaron varios fragmentos cerámicos entre los que se incluyen ánforas de tipo «fenicio-sardo", platos fenicios con y sin engobe rojo, fine ware, así como cerámicas a mano autóctonas, algunos fragmentos de cerámica griega y vilanoviana importados (López Castro et alii, 2020C: 1324 , fig. 5: k-t).

Una datación absoluta Beta-405200 2700 $\pm 30 \mathrm{BP}$ 905 [830] $805 \mathrm{cal}$ AC, efectuada con una muestra de semilla procedente del estrato $2 \mathrm{IO} 35$, situado junto al muro 21003, fecha la construcción de los muros de este segundo edificio y los hornos asociados, que vendría a coincidir con bastante exactitud con la fecha de abandono del edificio más antiguo.

\section{Resultados de la excavación en la Zona I}

\subsection{El Sector 21 del corte 10: una vivienda del área urbana}

En la campaña de 2016 la excavación se ha centrado en los sectores 21 y 22 del corte ro (figura I9). El sector 2I ya había sido objeto de estudio en la campaña de 2013, pero tan solo habían sido excavados los niveles superficiales. El sector 22 es de nueva denominación, comprende el área situada al noreste de los sectores 9 y 19 y supone una ampliación del corte io en la mencionada dirección.

El sector 2I se sitúa en el lado oeste del corte Io; presenta una forma más o menos cuadrangular y queda bien delimitado por las siguientes estructuras: el muro 10064 lo cierra por su parte más occidental, mientras que el flanco oriental lo compone el muro I0082; en el norte aparece el muro Ioo84 y por el sur la esquina que conforman los muros 10082 y roo64. En la campaña de 2016 se ha continuado la excavación iniciada en años anteriores (figura 20).

El primer estrato documentado corresponde a la UE I033I (figura 2I), un relleno de amortización realizado en época tardo fenicio-púnica o más probablemente en época romana. El siguiente estrato documentado bajo la UE ro33 es la UE ro333, que se localiza en el área suroeste del sector. Es un relleno de color grisáceo que contiene gran cantidad de carbones y material cerámico, con una potencia máxima de unos $12 \mathrm{~cm}$.

Paralelo al paramento occidental del muro IO226 se documentó la UE I0332, de color marrón y matriz limo-arcillosa, que es interpretada como el sedimento que rellena la fosa de expoliación de la canalización ro2I4, localizada en el sector I4 y que continuaría por esta parte del corte ro hasta desembocar probablemente en la estructura hidráulica de mayor envergadura, la canalización 10278, ubicada en el sector I3 (figura I9). Por su parte la UE ro334 se identifica con la fosa de cimentación del muro Ioo64.

A medida que se profundizó en la excavación aparecieron nuevos sedimentos como las UUEE ro343 (figura 23), І0345, І0346, І0347 у I0348 (figura 24), que presentan diversas manchas de coloración dependiendo del aporte de restos de alzado de muro de adobes y suelos de construcción de arcilla. Varían desde el color amarillo-verdoso a otra coloración más rojiza, conteniendo aportes de cal y piedras de derrumbe. El material cerámico de estas unidades es aparentemente uniforme: destaca la aparición de ánforas africanas de la serie 7 de Ramon, algunas ánforas de importación itálica, cerámica fina campaniense A y vajilla de cocina. 


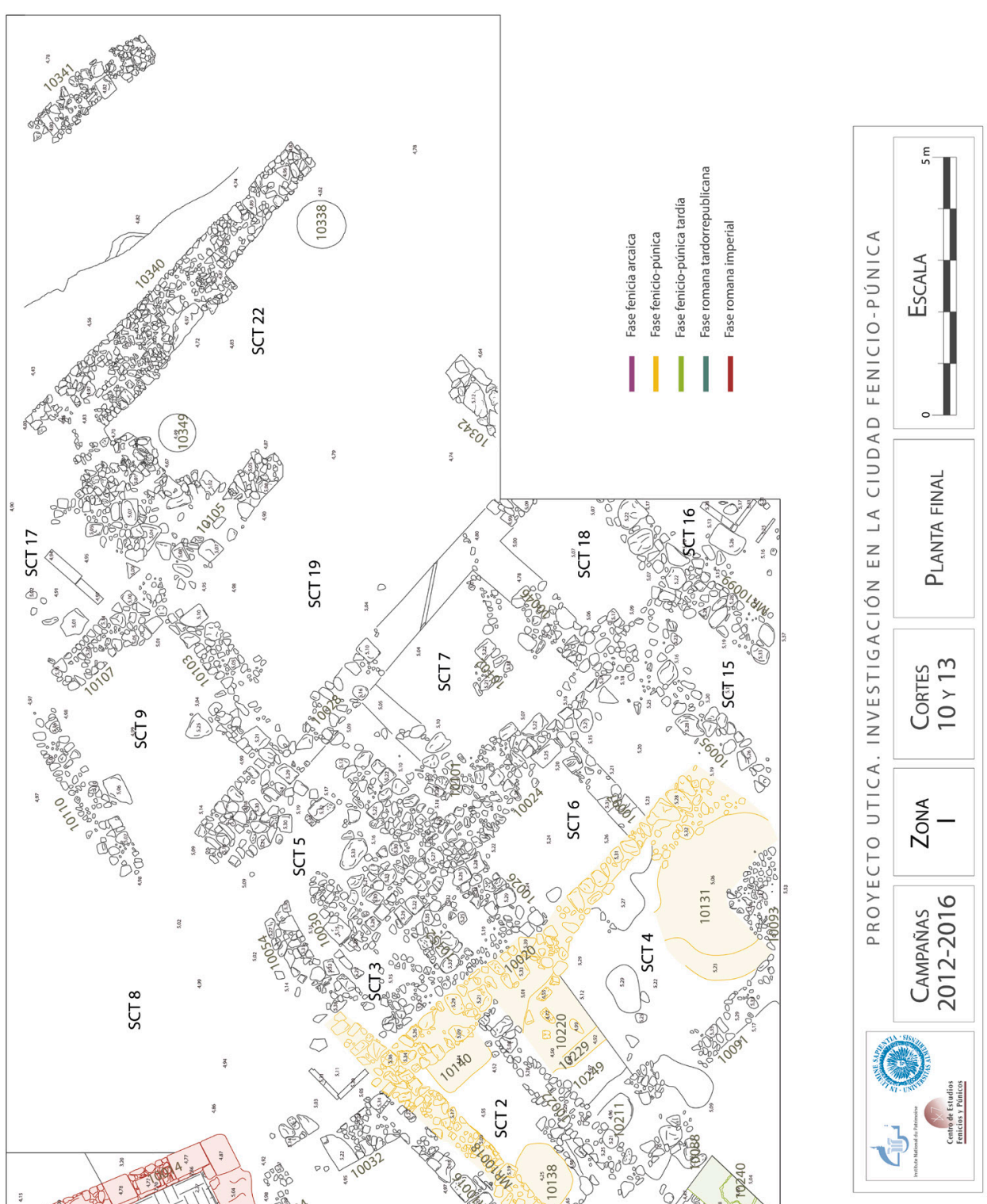




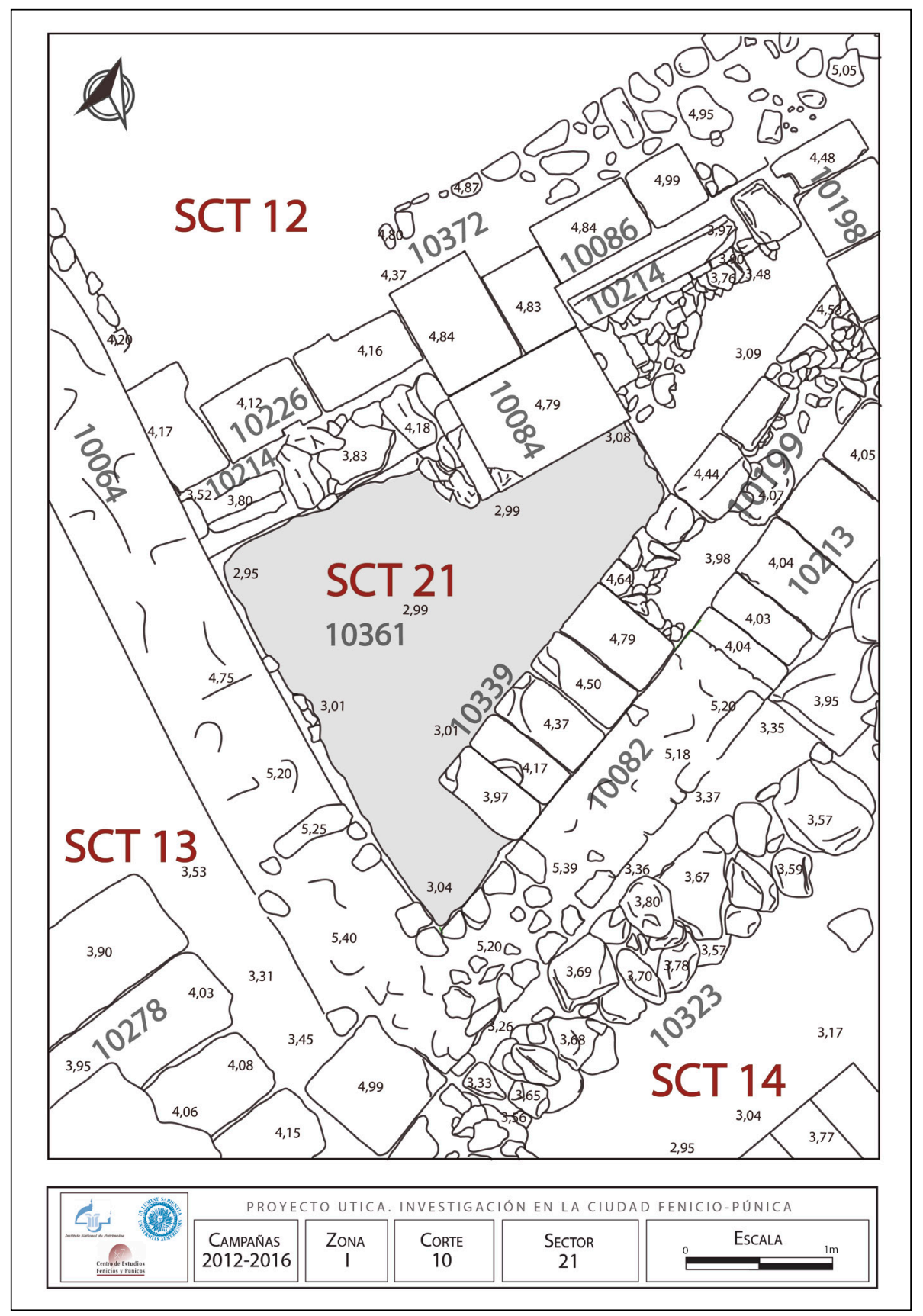

Figura 20. Corte 10, planta del sector 21

Figure 20. Trench 10, plan of sector 21

E1 sedimento que se extiende por todo el sector en este punto de la excavación es la UE ro356. En su mayor parte se trata de un paquete de deposición de relleno con coloración parda con restos de materiales de construcción y cerámica, de los mismos tipos que los estratos anteriores. Bajo esta unidad se distingue una nueva, la UE ro357, de composición igual a la anterior, aunque con una mayor deposición de fragmentos de ánforas (figura 20).
En la parte más meridional del sector, entre los muros 10084 y rorg9 y la escalera ro339 también aparecieron numerosas piedras apoyadas en el muro 10084 , posiblemente fruto de la colmatación generada por el derrumbe del muro posterior roig9. Cabe reseñar la gran cantidad de carbones que se documentaron y que parte del material cerámico, en su mayoría grandes contenedores, se encuentra muy rodado. En el extremo noreste del muro Ioo84 


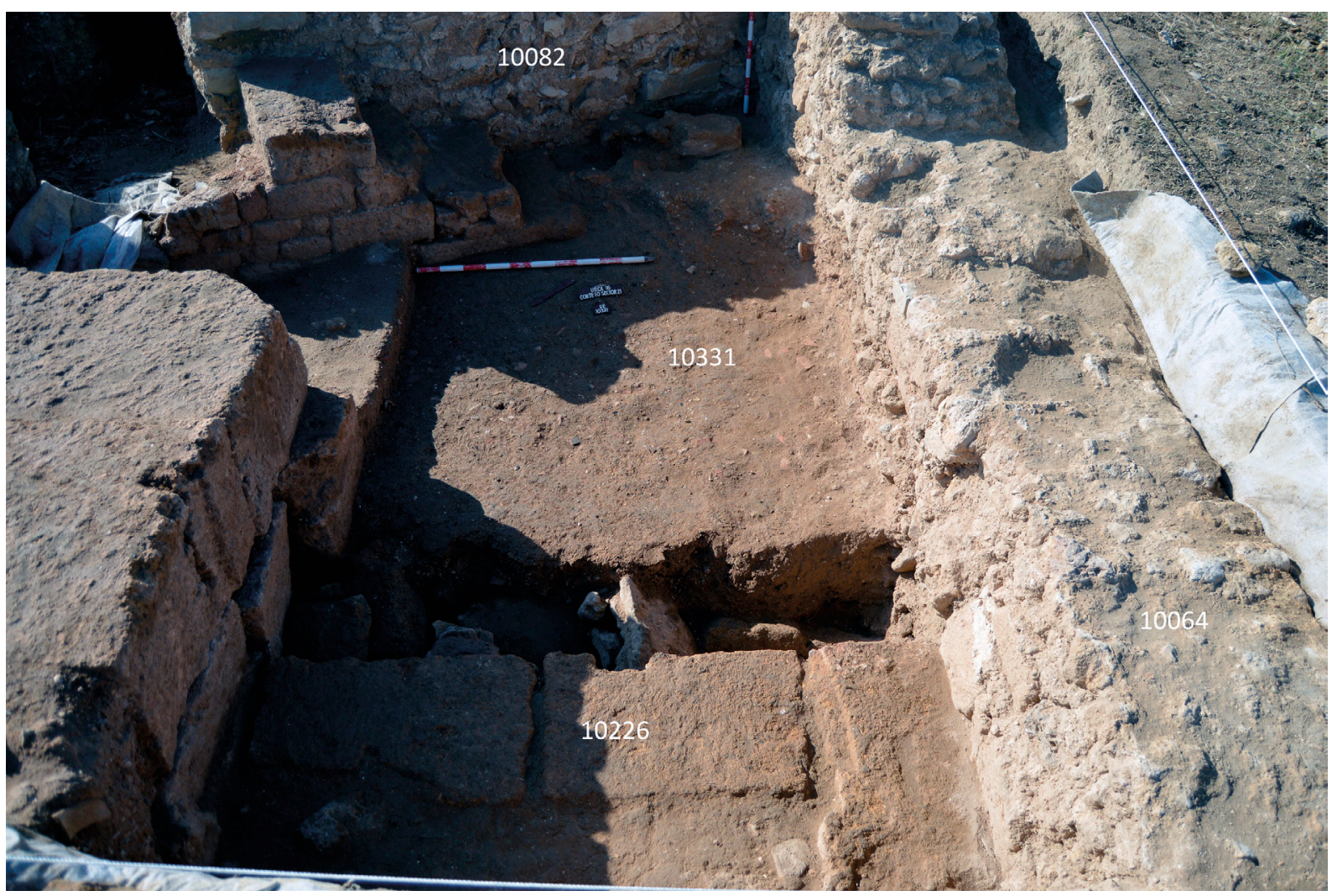

Figura 21. Corte 10 , sector 21 , unidad estratigráfica 10331

Figure 21. Trench 10, sector 21, stratigraphic unit 10331

nuevamente se observaron una serie de piedras de tamaño mediano que formaban un derrumbe. Junto a la escalera ro339 apareció un estrato amarillo que buza hacia el oeste y se identifica con la UE ro359 que parece una mancha de preparación de argamasa.

La excavación de este sector ha permitido comprobar que el extremo más septentrional del muro ror99, compuesto por sillares y adosado al muro I0082 por su cara occidental, se corresponde con una escalera Io339 de cinco peldaños, y que el muro rorg9 en realidad sirve para sustentar tal estructura (figura 9, figura 23, figura 26) Bajo las UUEE ı0357, I0358 y 1036o se descubrió un pavimento de opus signinum, el pavimento I036r, que podemos incluir dentro de los $p a-$ vimenta punica por sus características. El pavimento parece continuar debajo de la escalera, que lo cubre y ocupa la totalidad del sector 2I (figura 27).

Las cerámicas recuperadas en las unidades estratigráficas depositadas sobre el pavimento I036I pueden aportar información sobre la cronología de su amortización, y del edificio del que formaría parte, relacionada con la construcción del muro de aterrazamiento I0082. Estos estratos contienen material cerámico de diferentes formas y producciones situadas hacia finales del siglo iı a. C. A las ánforas de importación pertenece un ejemplar (figura 28: 10604-I) dotado de un borde triangular en el que la parte superior está inclinada y la inferior es horizontal, y con un cuello alargado, casi cilíndrico, sobre el cual se disponen las asas verticales de sección oval. Es una forma que corresponde a los tipos Will 1c y MGS VI (Will, I982; Vandermersch, I994: IO3-IIO). En la reciente clasificación de estas ánforas greco-itálicas establecida por F. Cibecchini y C. Capelli, nuestro ejemplar se inscribe en el grupo VIa fechado entre 210-I9O a. C., cuyos bordes son variados y pueden confundirse fácilmente con los del grupo $V_{c}$ de fecha ligeramente anterior (Cibecchini y Capelli, 2013: 440-443, fig. 9). Producidas en la zona campano-latina, con presencia en Ischia, estas formas, conocidas en pecios y yacimientos terrestres de la cuenca occidental del Mediterráneo, reflejan una fase de intensificación de la distribución del vino itálico, que ya había comenzado a mediados del siglo iII a. C. 

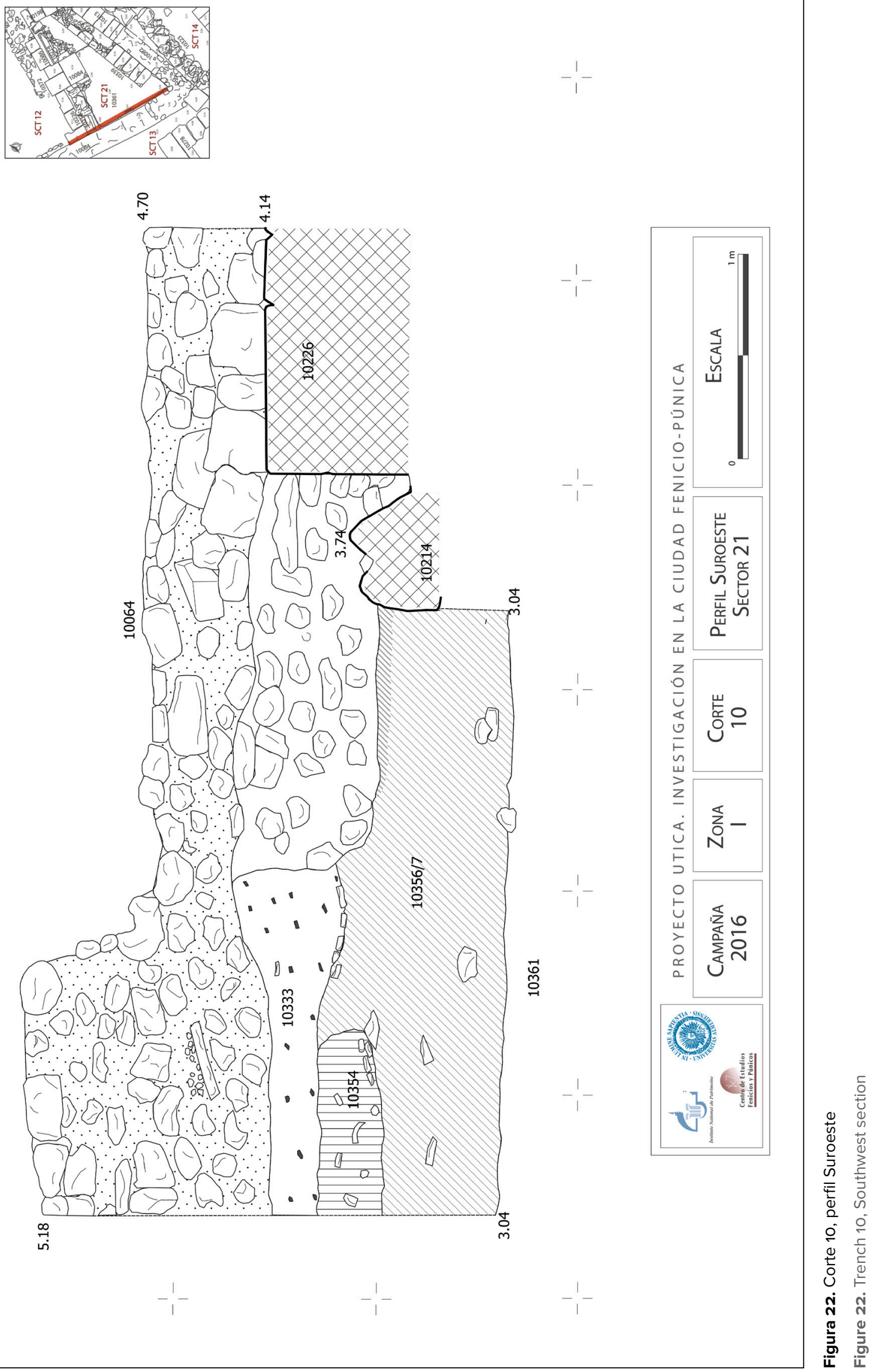


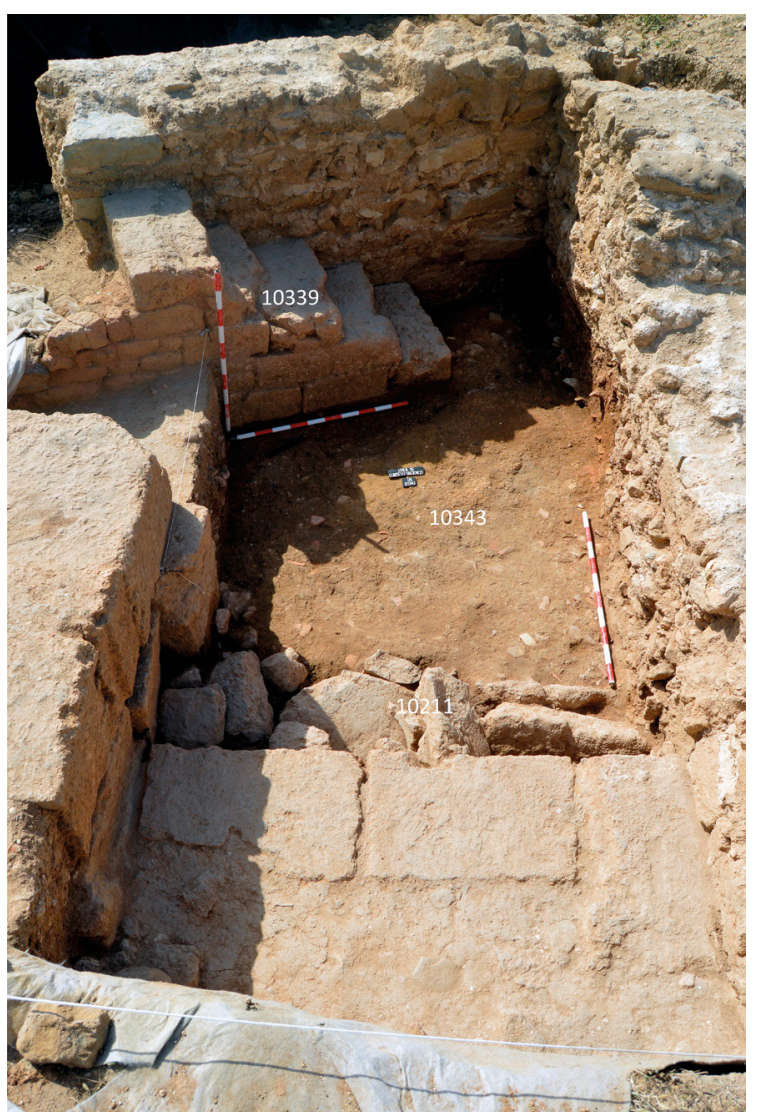

Figura 23. Corte 10, sector 21, unidad estratigráfica 10343

Figure 23. Trench 10, sector 21, stratigraphic unit 10343

Las ánforas africanas están representadas en primer lugar por la forma de borde trífido (figura 28: I0584-I) clasificada como tipo Ramon T.7.4.3.I (Ramon, I995: 20I-2II), que también corresponde a la forma A de Van der Werff I = Maña $\mathrm{C}_{2}=$ Martin-Kilcher (Van der Werff, 1977-1978; Martin-Kilcher, 1999). S. Martin-Kilcher insistió en la distinción que debe hacerse desde el punto de vista del origen entre su tipo A, perteneciente principalmente a la zona de Cartago, y su tipo B, característico de la Bizacena (Martin-Kilcher, I999: 4I4-4I5). Es a esta última zona a la que parece pertenecer el borde que presentamos (figura 28: 10604-2) del tipo Ramon T. 7.5.I.I. Según J. Ramon, este tipo, fechado en la segunda mitad del siglo in a. C., se producía en el Sahel tunecino (Ramon, 1995: 214, 217-219). De hecho, en un reciente estudio de las ánforas de Uzita, un yacimiento situado en esta última zona, encontramos este tipo de ánforas en contextos posteriores a ${ }^{4} 6 \mathrm{a}$. C. (Perugini, 2015: 178).

Además de las ánforas, han aparecido cerámicas de cocina. Incluyen formas de importación itálica, así como una producción africana similar a la definida por J. Freed como Byzacena Blacktop Red Cooking Ware. A la primera categoría pertenece el plato rojo pompeyano atestiguado antes del 50 a. C. en yacimientos como Bolsena y Polentia (figura 28: 10604-3) (Goudineau, I970: I66, pl. I, I-2; Py, I990: 589). En Atenas, esta forma, que parece ser una creación de la Italia central, está presente durante el siglo II a. C. (Thompson, I934: 139-I40). Otras formas africanas son una tapadera de tipo 70 Vegas (figura 28: 10584-6) (Vegas, 1999: 198-199) y una lopas de tipo 69 Vegas/ II.2. Guerrero (figura 28: 10584-4) (Vegas, I999: I98; Guerrero, 1995), ambas presentes en Cartago en los niveles tardíos de Byrsa y en la fase púnica tardía de las excavaciones del área de Bir Messaouda (Lancel, I982: 30, fig. 23; Bechtold, 20Io: 44, fig. 26.3 y 58 , fig. 33, 2). En Leptiminus, en el Sahel tunecino, este último tipo de cazuela Guerrero II../Hayes I9I (Hayes, I976), no parece ser más antiguo del siglo II a. C. (Freed, 1998: 22).

En cuanto a la tapadera de producción común local o regional (figura 28: $10584-5$ ), se clasifica como tipo 8I.I Vegas/tipo 9Irar Lancel (Lancel, I987: II5, pl. 20) conocido de los niveles posteriores de Cartago Byrsa. Sin embargo, ejemplos similares al de Utica siguen estando presentes en contextos posteriores que se remontan al siglo i a. C. y a principios del siglo siguiente (Fulford, I994: 67, fig. 4.IO.26.3, forma 26; Hayes, 1976: 66, fig. 7.22; I04, D.9, fig. I7, deposit XIII, early Roman lid type I).

La vajilla de mesa también está presente con fragmentos de piezas de barniz negro; mencionamos en primer lugar la presencia de los cuencos campanienses del tipo Lamboglia 28a-b (figura 28: 10604-5) (Lamboglia, I952: I77-I78) y Lamboglia 3Ib (figura 28: 10604-4) (Lamboglia, I952: I80-I8I). La primera forma se considera una de las primeras importaciones de la Campaniense A; se atestigua en Lattes a partir de mediados del siglo in a. C. y solo empieza a decaer notablemente hacia finales del siglo siguiente (Py et alii, 20or: 476-477). El segundo cuenco, típico del repertorio clásico de la cerámica campaniense tuvo éxito a lo largo del siglo ir a. C.y de la primera mitad del siglo siguiente. En las excavaciones de Marsella, la frecuencia de esta forma aumenta durante la fase I, datada en el roo/9o-80 a. C. 


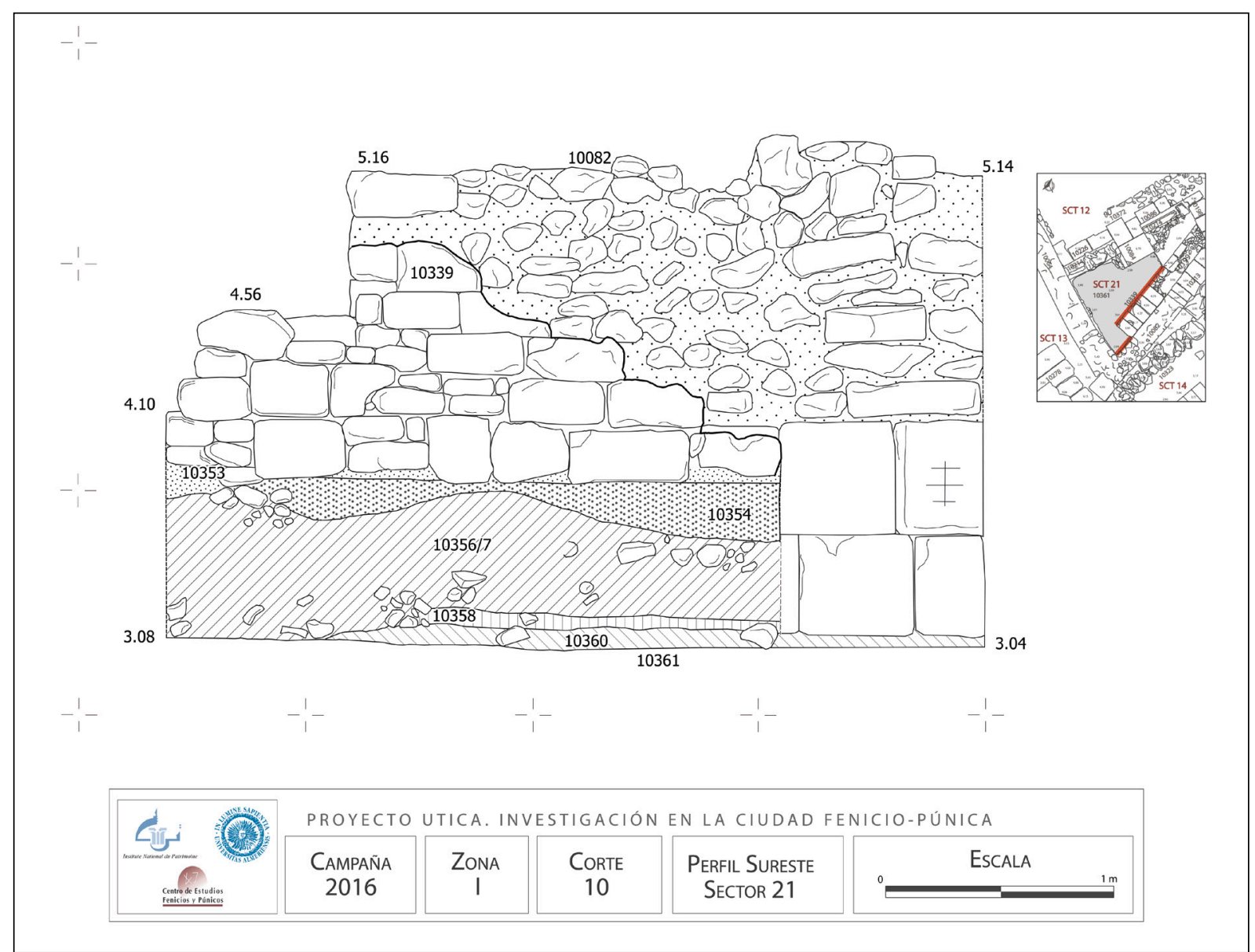

Figura 24. Corte 10, perfil Sureste

Figure 24. Trench 10, Southeast section

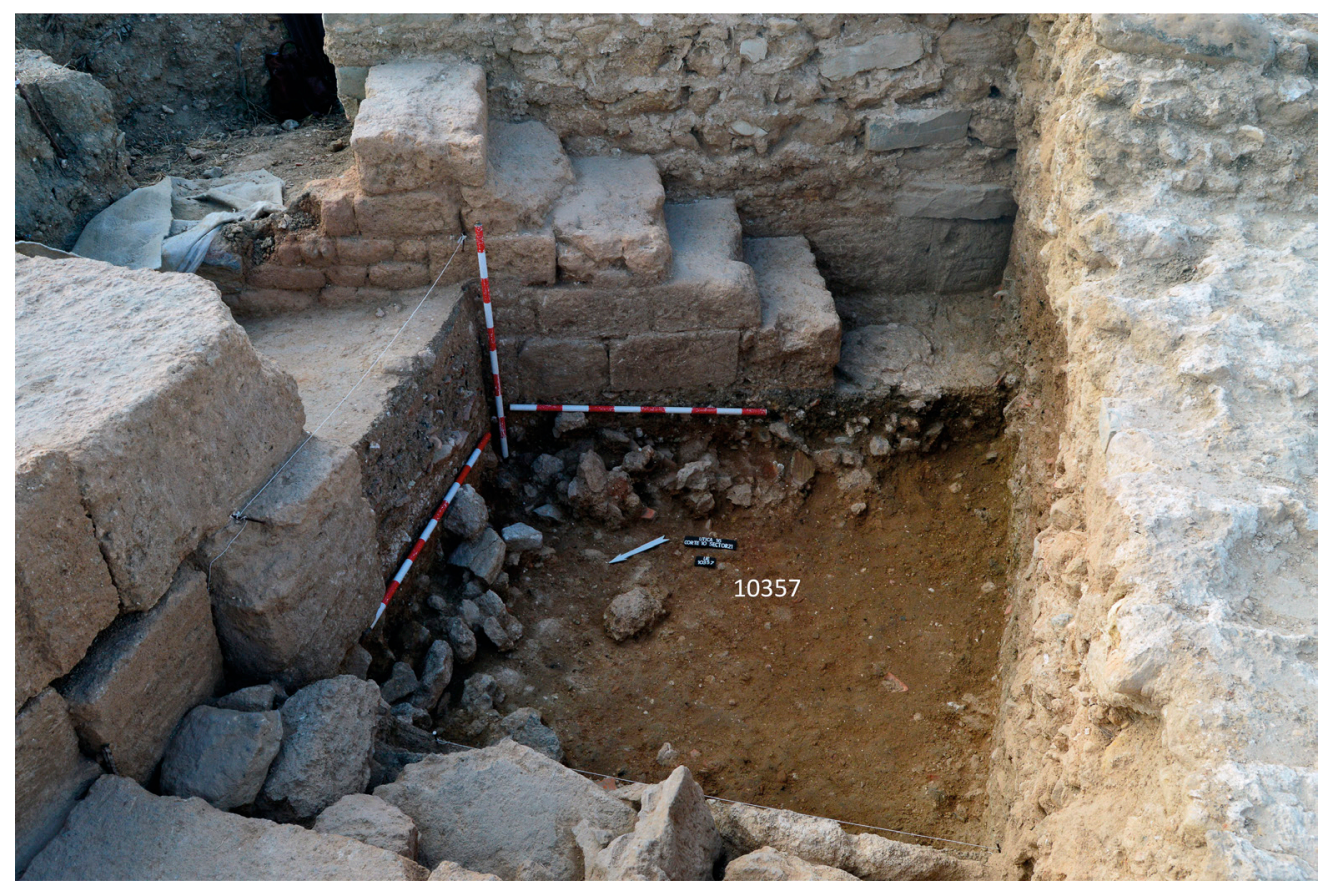

Figura 25. Corte 10, sector 21, unidad estratigráfica 10357

Figure 25. Trench 10, sector 21, stratigraphic unit 10357 


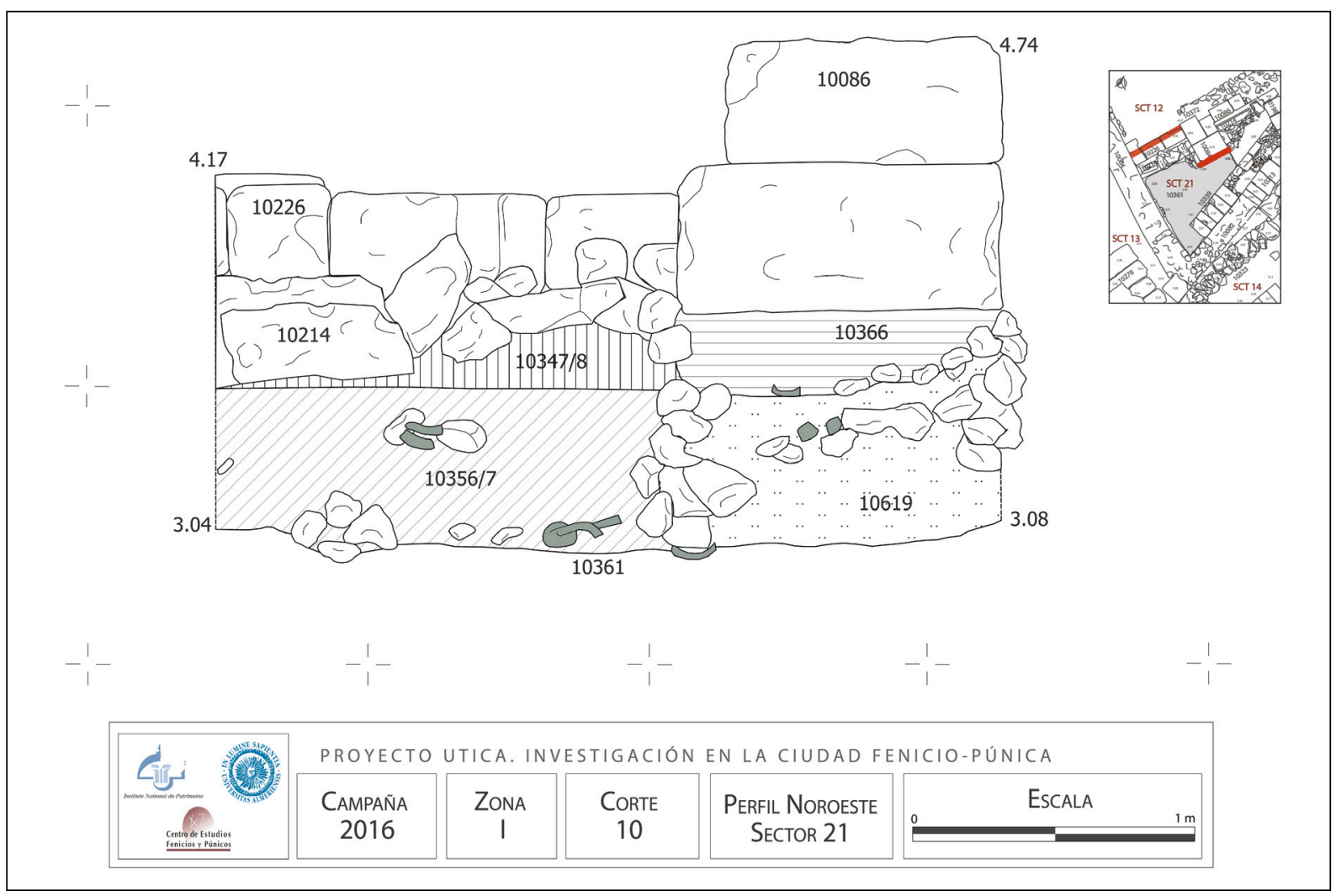

Figura 26. Corte 10, perfil Noroeste

Figure 26. Trench 10, Northwest section

(Cibecchini, 2007). Esta gran difusión a lo largo de este periodo también se constata igualmente en Lattes y en otros lugares del bajo valle del Ródano (Py et alii, 200I: 485).

La cerámica importada de barniz negro también está representada por un plato del tipo Morel II4O de Cales (figura 28: 10579-I). Datos recientes procedentes de excavaciones en Cartago confirman la aparición de este plato con borde ondulado justo antes de la mitad del siglo il a. C. (Bechtold, 2007: 9; Niemeyer et alii, 2007: 566). Por último, señalaremos que entre las imitaciones de barniz negro de Campaniense $B$ se encuentra un fragmento de cuenco del tipo Lamboglia I/Morel 2320 (figura 28: 10584-3) (Lamboglia, I952: I43-I44, Morel, I98I) que cierra este grupo de cerámicas.

\subsection{El Sector 22 del corte 10: una calle del área urbana}

Con la intención de conectar el espacio comprendido entre los cortes io y II, y al objeto de descubrir y datar dos muros paralelos detectados en la prospección geofísica de 20I2, se consideró oportuno ampliar el corte ro hacia el este, delimitándose así un nuevo espacio excavado que conecta el sector I9, ya explorado en campañas anteriores y el ahora denominado sector 22, donde se centraron los trabajos de esta campaña. La ampliación este alcanzó unas dimensiones de 9,20 × 9,60 m y pronto alcanzó el suelo geológico en la mayoría de los sectores (figura I9, figura 29).

En general, el espacio ocupado por ambos sectores se encuentra alterado por ocupaciones recientes, sobre todo en su parte más occidental, donde aparece un importante relleno de humus, la UE I0335, con escaso material arqueológico asociada a un muro muy superficial, roto y sin continuidad hacia el noreste, como es el muro I0342. La potencia de la UE ro335 es mucho menor en el ángulo noreste y en el centro del corte. Bajo ella se encuentra la UE ro337, de color amarillento y textura arenosa, con numerosos nódulos de arcilla y cal, además de algunos fragmentos cerámicos, escasos, poco significativos y de difícil adscripción cronológica (figura 29, figura 30). 


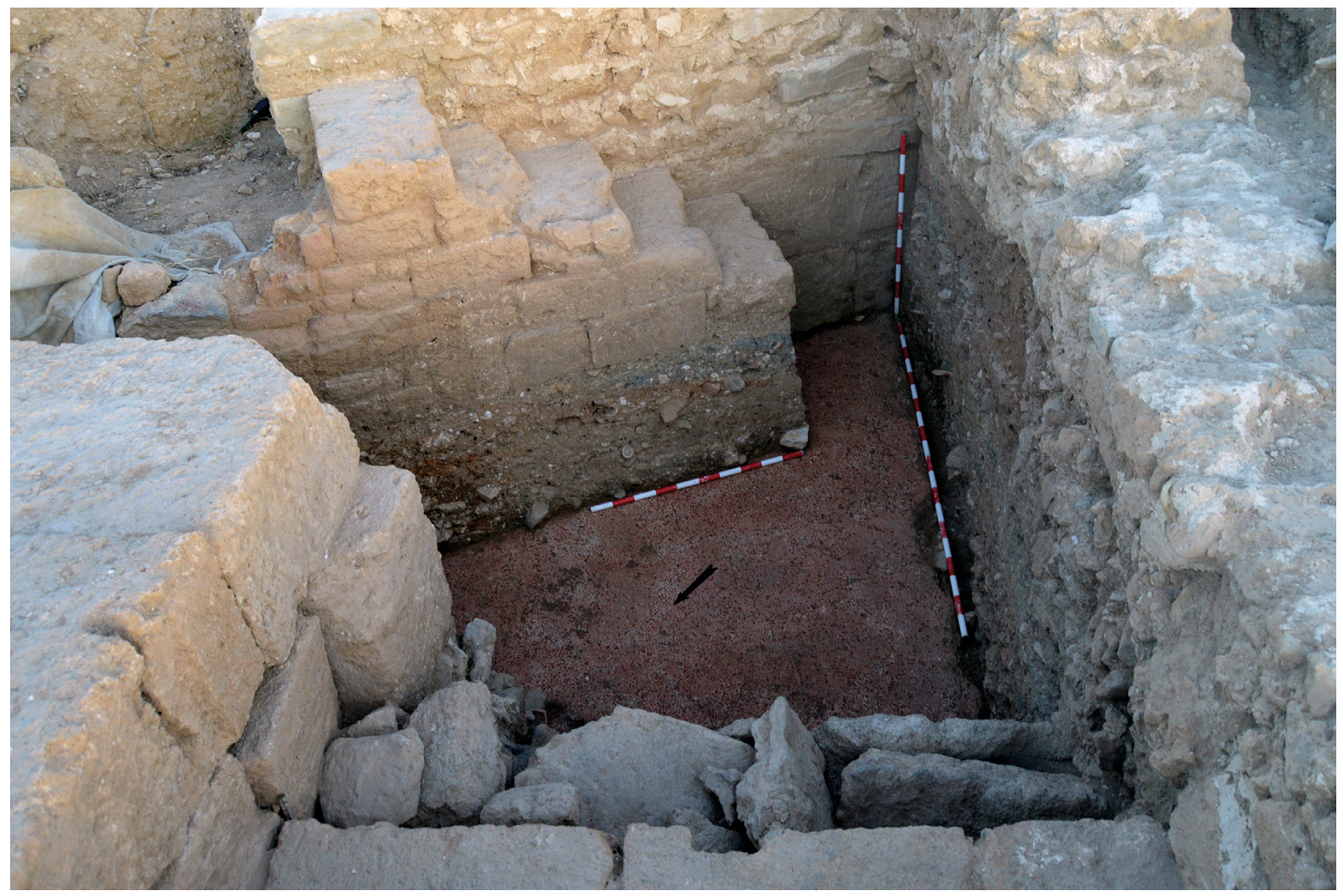

Figura 27. Corte 10, sector 21, pavimento 10361

Figure 27. Trench 10, sector 21, pavement 10361

La UE ro337 conecta directamente con el sector $19, y$ en concreto con el gran muro I0340 que parte del ángulo noroeste del mismo. Se trata de una construcción de 1,60 $\mathrm{m}$ de ancho en su mitad septentrional y i m en la meridional, que conserva unos 7,5 m de longitud. Está construido a base de piedras irregulares de pequeño y mediano tamaño y algún sillarejo. Se dispone en dirección noroeste-sureste, desapareciendo en esa dirección, debido a la proximidad de una fosa de expolio moderna. $\mathrm{La}$ mayor anchura de la parte norte se debe al recrecimiento de la cara interior del muro.

De similar factura y paralelo al anterior es otro muro que ocupa el ángulo Noreste del sector 22, el muro I034I, de o,8 $\mathrm{m}$ de ancho y unos $4 \mathrm{~m}$ de longitud conservados. La distancia entre ambos muros es de unos 3,5 $\mathrm{m}$ y podemos interpretarla como una calle que cerraría por el este la manzana formada por viviendas dispuestas en terrazas de habitación de época fenicio-púnica (figuras 29-3I).

Entre ambos muros aparece el estrato arcilloso ya aludido, UE ro337, que se hace aquí más compacto en el centro con un ligero adelgazamiento hacia los extremos. Se interpreta como un suelo virgen resultado de la degradación de la UE I0352, en parte conservado en el extremo suroeste del corte y muy similar a la también cercana UE ro35r. El material cerámico es escaso y dispar: cerámicas de barniz negro y terra sigillata de los siglos I-II d. C., destacando varios fragmentos de un vaso figurado, típico de las producciones itálicas en barniz negro.

Por debajo de este estrato y adosadas al muro I0340 se identificaron sendas unidades estratigráficas, en sus extremos sur y norte, respectivamente las UE ro35o y ro349. Esta última, igualmente de matriz arcillosa y homogénea, se reconoce al otro lado del mencionado muro, y a su vez es cortada por una estructura negativa, la UE 10367, de o,75 $\mathrm{m}$ de ancho y de poca profundidad $-0,5 \mathrm{~m}-$, sin material que debió ser el final de un pozo similar al que encontramos al sur del muro I0340 (figura 3I).

En efecto, en el límite oeste del muro I0340, casi en el centro del sector 22, se identifica el pozo I0338, de perfil circular y color oscuro. Se trata de un pozo 


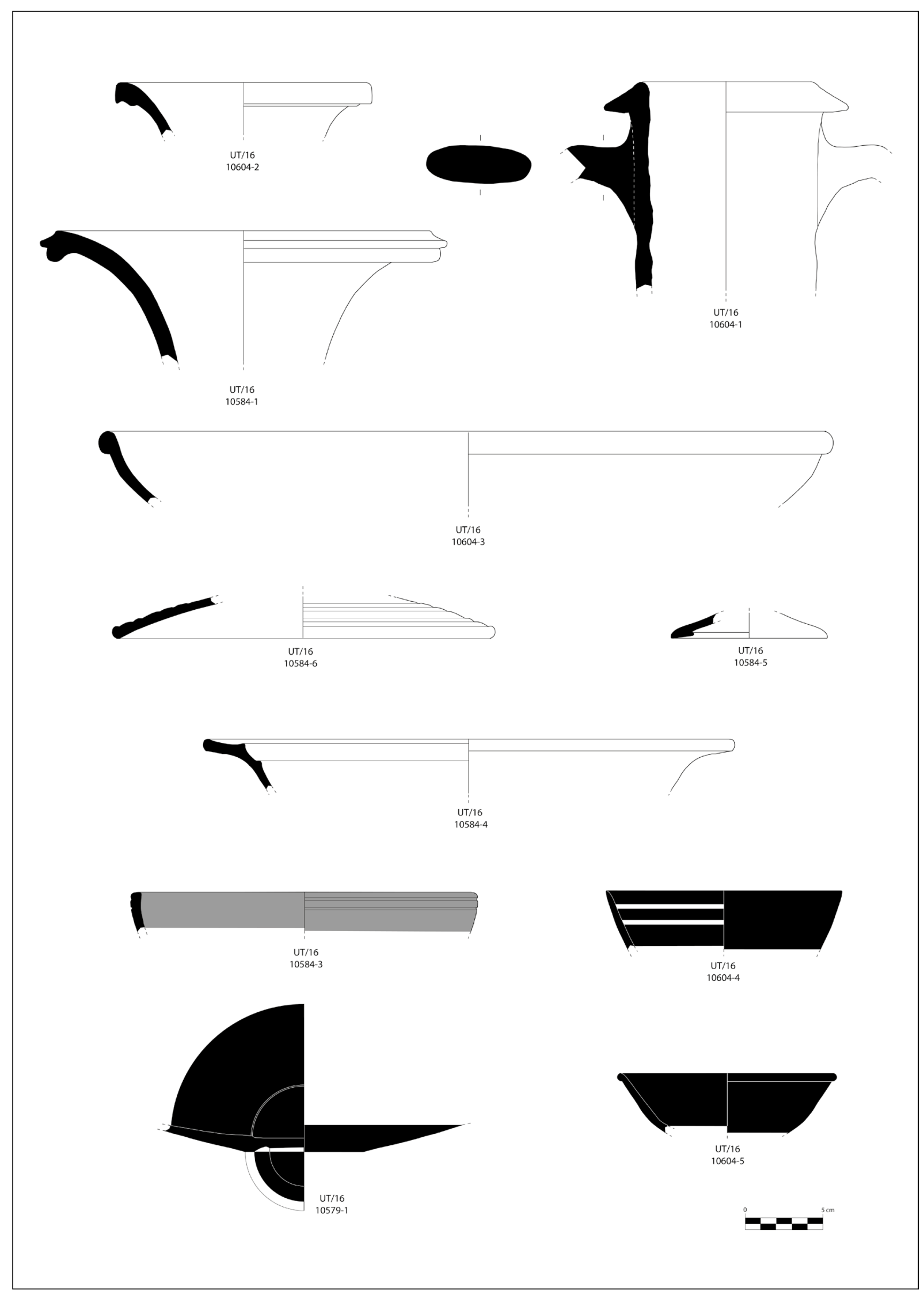

Figura 28. Corte 10, cerámicas de las unidades estratigráficas 10357 y 10358

Figure 28. Trench 10, pottery of stratigraphic units 10357 and 10358 


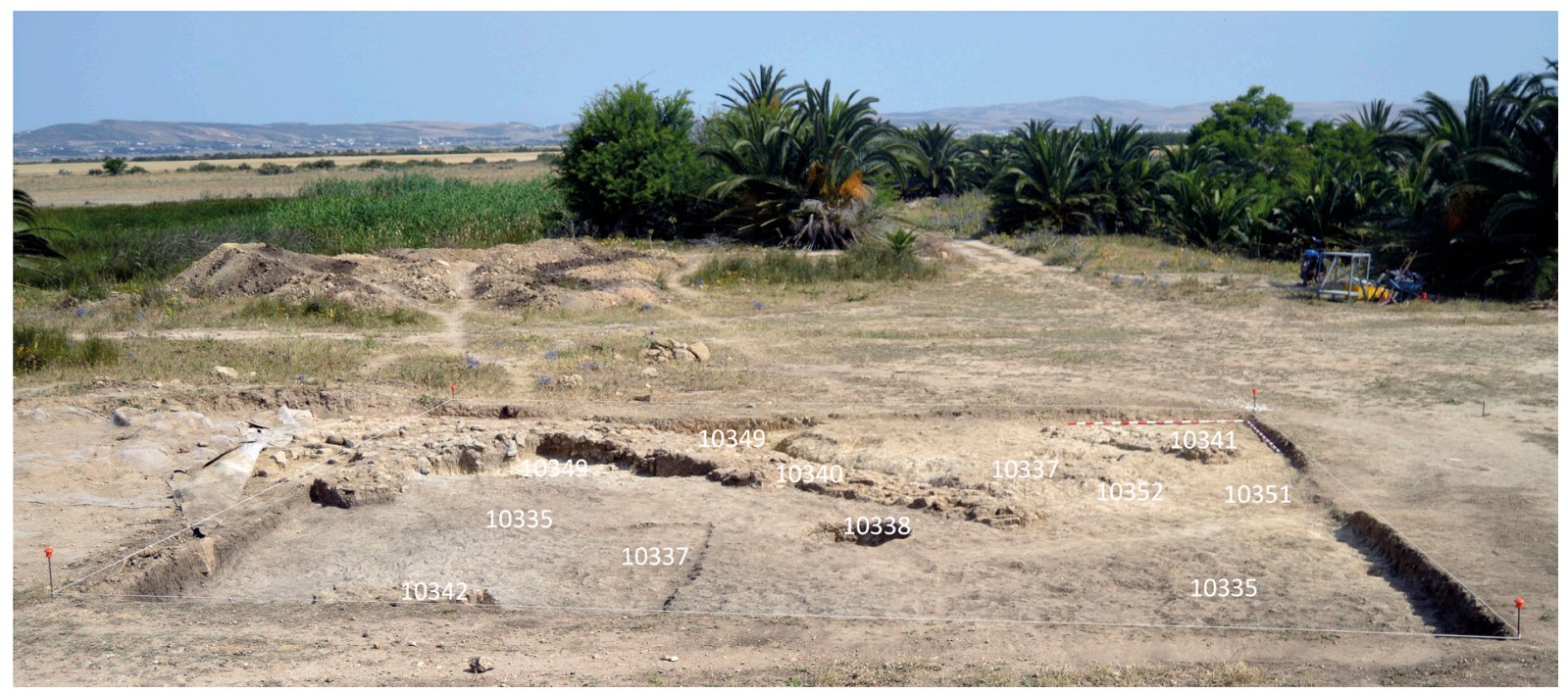

Figura 29. Corte 10, vista general de la excavación de los sectores 19 y 22 desde el sur

Figure 29. Trench 10, general view of the excavation of sectors 19 and 22 from the South

de unos $0,90 \mathrm{~m}$ de diámetro que ha sido excavado en su totalidad hasta alcanzar una profundidad de 2,80 m. El pozo estaba excavado en el nivel geológico y presentaba en su interior hendiduras regulares que servían como escalones. Su relleno, la UE ro367, es homogéneo, aunque presentaba en su nivel superior de colmatación una mayor concentración de carbones, con abundante material cerámico de época romana imperial, huesos de animales y fragmentos de metal, así como de material de construcción. En su final aflora el terreno virgen perforando el nivel freático (figura 32). Probablemente el pozo perteneció a estructuras romanas cuyo nivel de circulación estaría a una cota más alta, y que estarían superpuestas a las estructuras fenicio-púnicas conservadas. Las construcciones romanas a las que se asocia el pozo han desaparecido a causa del expolio $\mathrm{y}$ las destrucciones sufridas en el yacimiento en esta zona del promontorio de Utica.

\subsection{El corte 11 en el área de los templos. El sector $E$}

La campaña de 2016 se ha concentrado en este corte en la excavación en el sector $\mathrm{E}$ de un sondeo de $6 \times 2 \mathrm{~m}$, continuando los trabajos iniciados en 2015. Los objetivos eran determinar la continuidad del muro IIo97, que delimitaba el templo más reciente por el norte y comprobar si el muro giraba en algún momento al oeste delimitando el espacio. El sondeo se disponía al flanco norte de la cisterna romana reutilizada modernamente y construida sobre el edificio monumental mencionado, cuya construcción hemos podido datar en campañas anteriores hacia mediados del siglo iv a. C. (figura 33).

Tras la capa superficial, UE nio65, se localizaron muros de ladrillo y una conducción de agua moderna (muro III39 y canalización III40) relacionados con el aprovechamiento moderno del agua caliente del manantial vecino. Bajo estas unidades se disponían varios estratos de relleno (UUEE III4I a III45) (figura 34, figura 35) que contenían cerámicas modernas $\mathrm{y}$ medievales hasta llegar al fondo del sondeo a una plataforma de gran envergadura denominada muro III 46, de la que se conserva una hilada de gruesos bloques de distinto tamaño, en su mayoría rectangulares y alargados, dispuestos en dirección noreste-suroeste, con bloques más pequeños e irregulares rellenado los huecos entre los bloques alargados. En el perfil norte se pudo documentar la fase medieval del muro IIIIg, cuya dirección continuaba para formar parte de la construcción de una noria documentada en la campaña de 2015 (figura 34, figura 35).

Sobre esta plataforma se dispusieron grandes bloques de piedra con un relleno de piedras entre ellos que formaban posiblemente parte de una estructura casi desaparecida, el muro InI5 (figura 35). Aunque en la campaña se efectuaron sondeos en el interior de la 


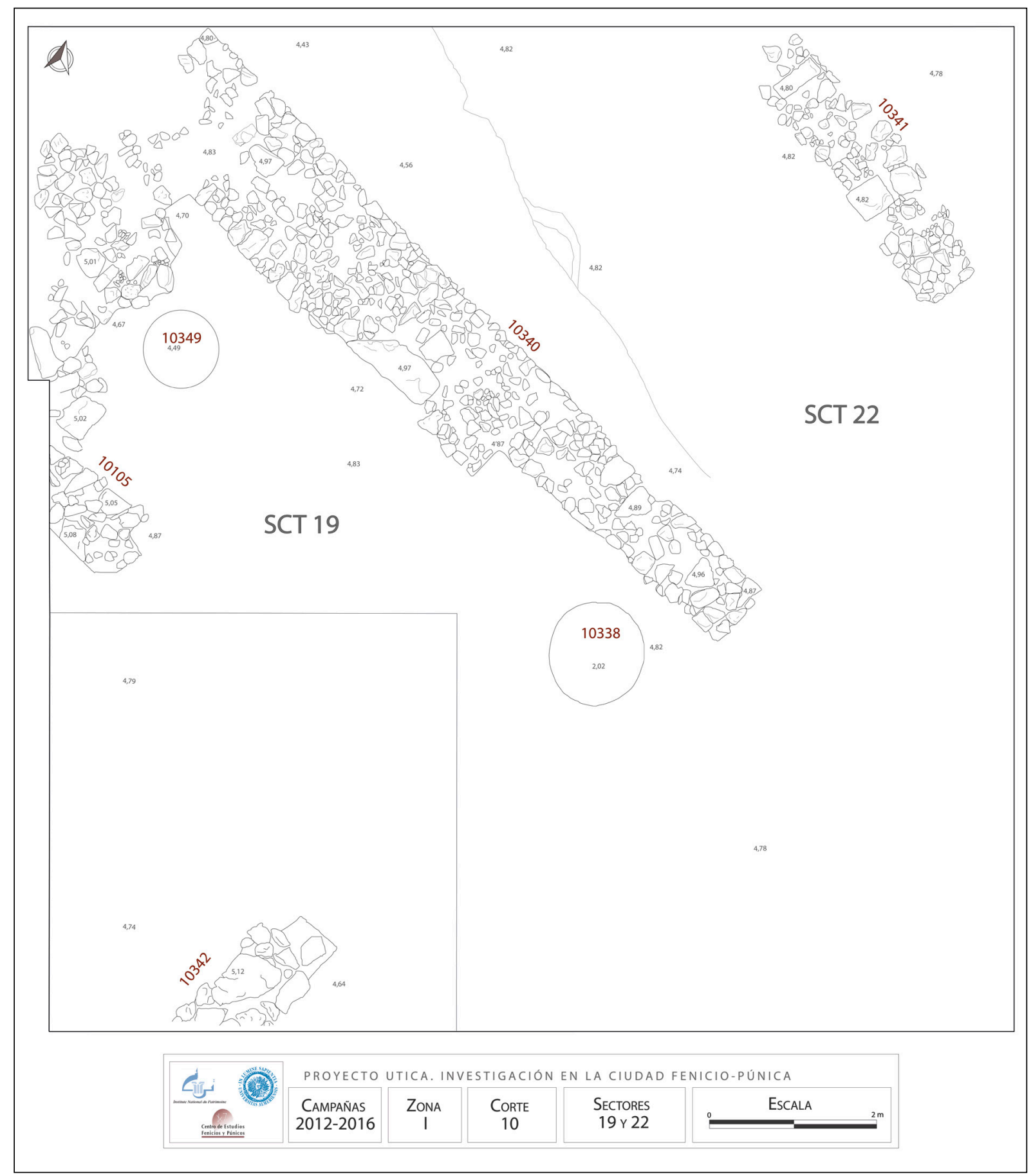

Figura 30. Corte 10, planta final de los sectores 19 y 22

Figure 30. Trench 10, final plan of sectors 19 and 22

estructura III46, en los espacios libres que quedaban entre los bloques, no se pudo documentar cerámica $\mathrm{u}$ otro elemento que pudiera proporcionar una datación, alcanzando pronto el nivel freático que, al igual que en campañas anteriores, amenazaba con inundar la excavación por su proximidad a la superficie. No obstante, la disposición y orientación de los bloques y las técnicas constructivas empleadas parecen apuntar a que se trataría de un muro antiguo, lo cual habrá de confirmarse en ulteriores campañas de excavación 


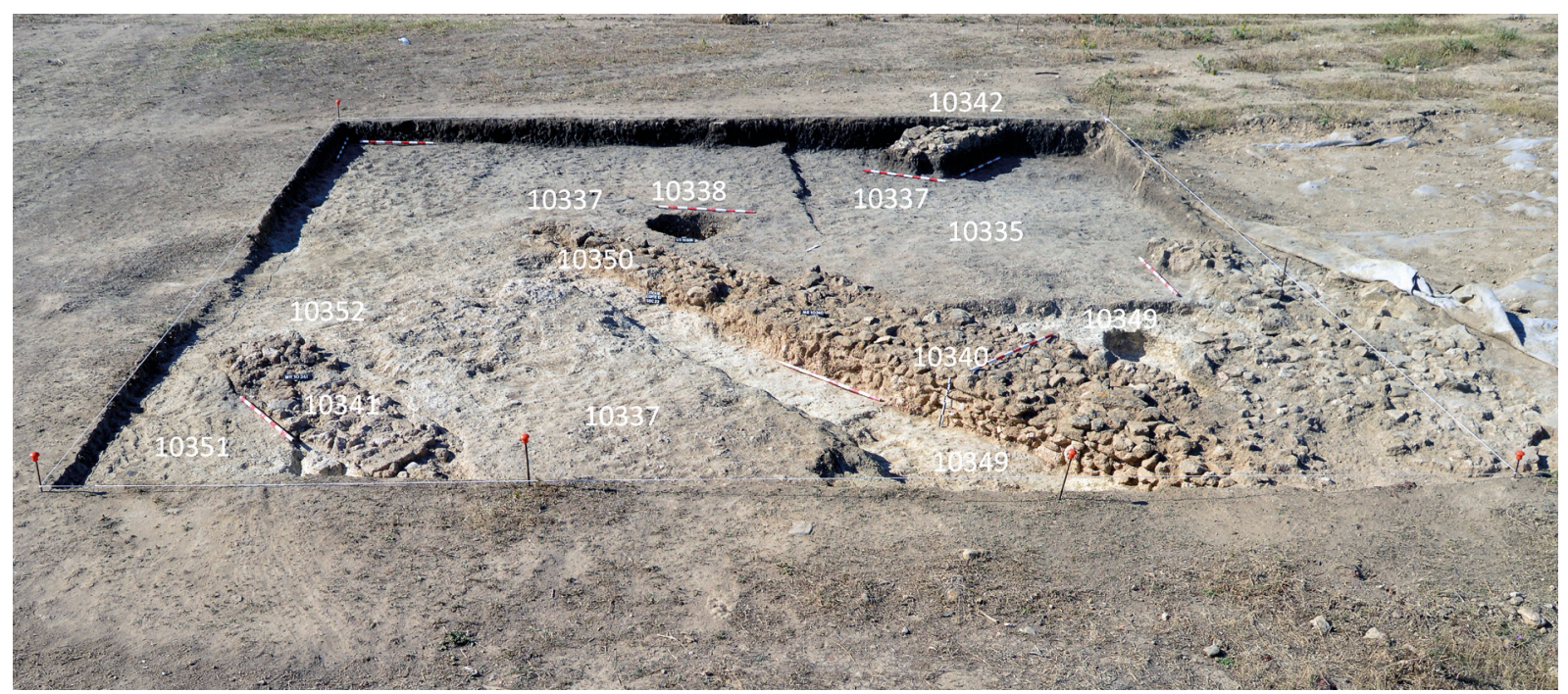

Figura 31. Corte 10, vista general de la excavación de los sectores 19 y 22 desde el norte

Figura 31. Trench 10, general view of the excavation of sectors 19 and 22 from the North

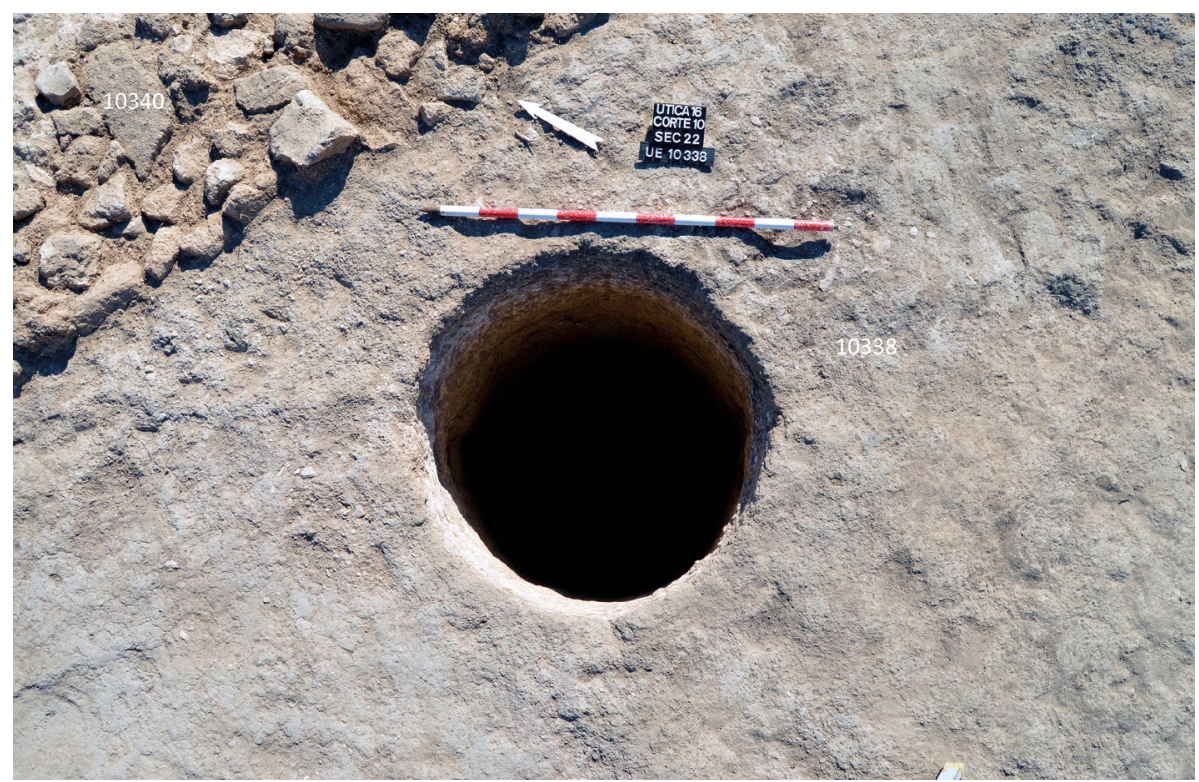

Figura 32. Corte 10, sector 19, pozo romano 10338 excavado en el suelo geológico

Figure 32. Trench 10, sector 19, roman well 10338 excavated in the geological soil

\section{Las aportaciones de la campaña de 2016}

En el corte 2I de la Zona II la campaña de 2016 ha puesto de relieve la importancia del muro fenicio 21088-21099 que delimitaba perimetralmente un edificio o un complejo constructivo del siglo IX a. C. por el norte. Este edificio se edificó cubriendo el espacio donde había estado en uso el pozo 20017 , clausurado hacia 1000-828 cal AC, según la datación absoluta más reciente (figura 9). Al oeste, el muro 2II39 que hace ángulo con el muro 21088-21099 podría delimitar el extremo occidental del edificio, con lo que sus dimensiones podrían alcanzar al menos I2 $\mathrm{m}$ de longitud, pues su extremo oriental se ha perdido (figura 9). En el extremo oeste del edificio se ha localizado un posible vano con un suelo en el que se documentaron cerámicas arcaicas fenicias y griegas geométricas en posición, así como trazas de actividad metalúrgica de hierro. El estudio preliminar de las cerámicas de las UE 2II24 y 2IIOO muestra su coherencia y sitúa la datación del edificio en 


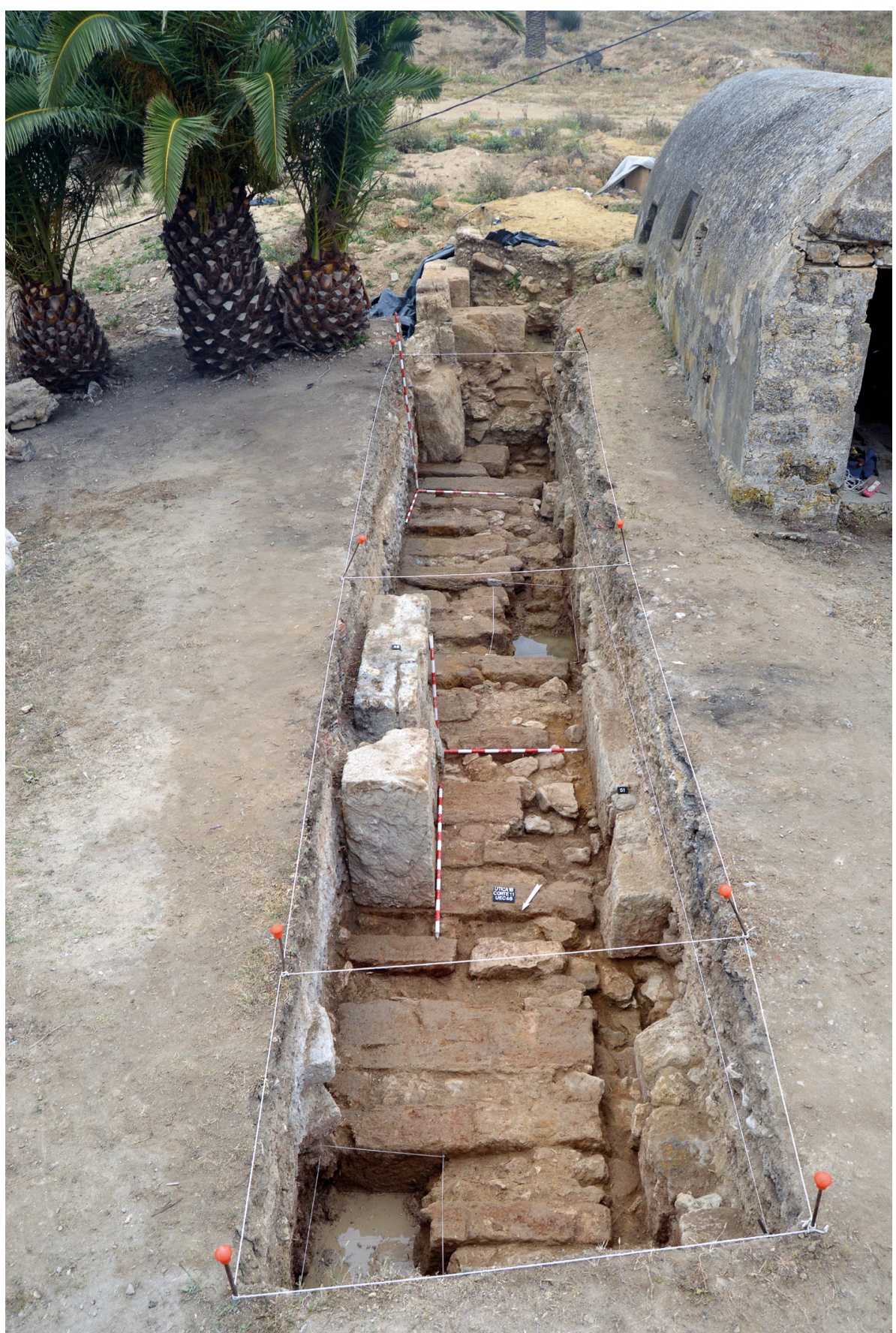

Figura 33. Corte 11, sector E: vista general de la estructura 11146

Figure 33. Trench 11, sector E: general view of the structure 11146

concordancia con las dataciones absolutas efectuadas con anterioridad a 915-735 cal AC, situando el periodo de su funcionamiento entre 997-839 cal AC y $905-806 \mathrm{cal} \mathrm{AC}$.

Bajo este edificio se ha encontrado un nuevo pozo, 2II3I, cegado y amortizado con la construcción del muro 21088-21099 (figura I6), por lo que este pozo sería anterior al edificio fenicio y constituiría una segunda fase constructiva tras la que supone el pozo 200I7. La amortización de este primer edificio sería una tercera fase constructiva que viene a coincidir con la construcción de un segundo edificio muy mal conservado, con diferente orientación, delimitado por los muros 21085-21003 y asociado a hornos domésticos de adobes, que se puede situar en $905-805 \mathrm{cal} \mathrm{AC}$ y que sería la cuarta y última fase 
constructiva fenicia antigua reconocida por el momento (figura 9). Las investigaciones que se desarrollan en el área baja más occidental del promontorio norte de Utica muestra una intensa ocupación fenicia, con varias fases constructivas en un intervalo cronológico promedio de alrededor de un siglo y medio, que en términos de cronología absoluta calibrada podríamos situar entre c. 950-810 cal AC.

La ampliación al norte del corte $2 \mathrm{I}$ ha descubierto que la fosa 21098 es de grandes dimensiones y tuvo como objetivo el expolio de un muro de sillares de enormes proporciones, el muro 2II32, cuya funcionalidad y datación no se ha podido determinar en esta campaña (figura 9), pero que debe pertenecer a un gran edificio o a una construcción defensiva de cronología aún por determinar, teniendo en cuenta su anchura de unos $2 \mathrm{~m}$ y una longitud ya descubierta de más de $5 \mathrm{~m}$. En todo caso se trata de un muro perteneciente a una edificación de grandes proporciones, cuyos sillares fueron expoliados, dejando en posición solo las hiladas de sillares más profundas y más difíciles de extraer.

La excavación de la fosa de expolio ha permitido reconocer la compleja técnica constructiva empleada. Tras efectuar un profundo rebaje del suelo geológico, destruyendo y afectando a la estratificación precedente más antigua, se construyó el fundamento del muro a una profundidad que no hemos podido determinar en esta campaña. Los taludes fueron revestidos de muros de mampostería trabados con un mortero de arcilla, probablemente para reforzarlos dado que el sustrato geológico es de greda, y no de roca. En su interior se haría crecer el muro de sillares superponiendo hiladas que fueron posteriormente expoliadas, salvo las más profundas. Quedan restos de estos muros perimetrales de recubrimiento del talud, en concreto lo muros 2IO9I-2II27, 2III28 y 2II29, parcialmente destruidos seguramente durante el expolio de los sillares. Es probable que hayamos descubierto uno de los vértices de la construcción, si tenemos en cuenta que los muros de revestimiento de los taludes 2IO9I-2II27 y 2II28 forman un ángulo sobre el gran muro $2 \mathrm{II}_{32}$ que es perpendicular a las estructuras 2II29, 21087 y 20II2, asentadas sobre la greda geológica. Estas estructuras podrían constituir la cimentación de un muro no conservado perpendicular al gran muro 2II32, que también formaría parte de esta gran construcción que en su cimentación emplea sillares en las esquinas, como es el muro 2109I-2II27.

$\mathrm{La}$ alternancia de hileras de sillares de piedra con fábrica de mampuestos y arcilla, seguramente para ahorrar sillares, empleada en la estructura 21087 recuerda la técnica similar empleada en el corte II, como muestra la estructura III46-III5I descubierta en el sector E. Parcialmente expoliada, la estructura se construyó también sobre un talud y se compone de un aparejo que dispone hiladas a soga e hiladas a tizón superpuestas, dejando entre los sillares alargados espacios rellenos de tierra, arcilla y mampuestos irregulares (figuras 34-36). Sobre esta sólida estructura se edificó el muro perimetral ro57 del Templo B del siglo iv a. C., que conserva apenas la hilada inferior de sillares a soga unidos por grapas de cola de milano, técnica también utilizada en los sillares del muro 2II32 del corte 2I.

El empleo de esta técnica constructiva que alterna hiladas de sillares a soga y tizón con fábrica de mampuesto se conoce en Fenicia desde el siglo $x$ a. C. hasta época persa y se extendió hasta época helenística con diversas variantes (Sharon, 1987: 28-29). Es probable que la documentada en Utica tuviera allí su origen al igual que el empleo del podium como hemos propuesto para la construcción de los templos A y B de Utica (López Castro et alii, 20r6c). Aunque no se ha podido datar en 2016 la estructura localizada en la ampliación del corte 11, podemos aventurar la hipótesis de que podría formar parte de la fundación de los muros del templo del siglo iv a. C. por su orientación y técnica constructiva. Debido a la base geológica de greda arcillosa existente en el yacimiento y a su proximidad al agua de la línea de costa en la Antigüedad, el templo necesitaría de una base sólida para soportar el peso de construcciones monumentales. La datación de la estructura III46-III5I solo podrá ser confirmado con nuevas investigaciones (figura 37).

En el área occidental de la Zona I, la excavación del sector 2I del corte to ha proporcionado la identificación de la escalera ro339 del siglo in a. C. adosadas al muro de aterrazamiento roor8 de la misma fecha. Ambas estructuras se construyeron sobre una terraza de habitación situada a una cota sensiblemente inferior, en la que se ha descubierto una estancia con un 


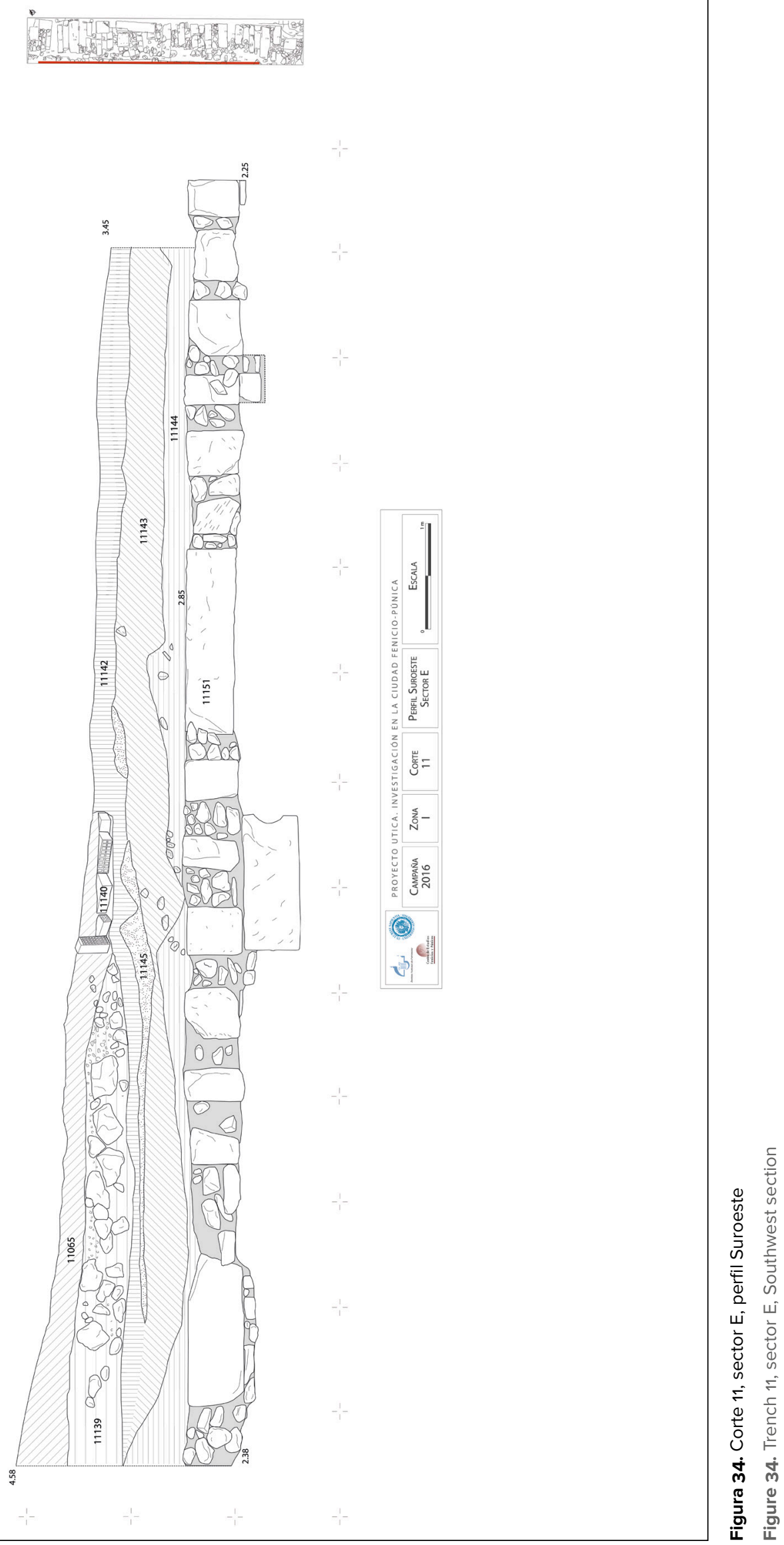



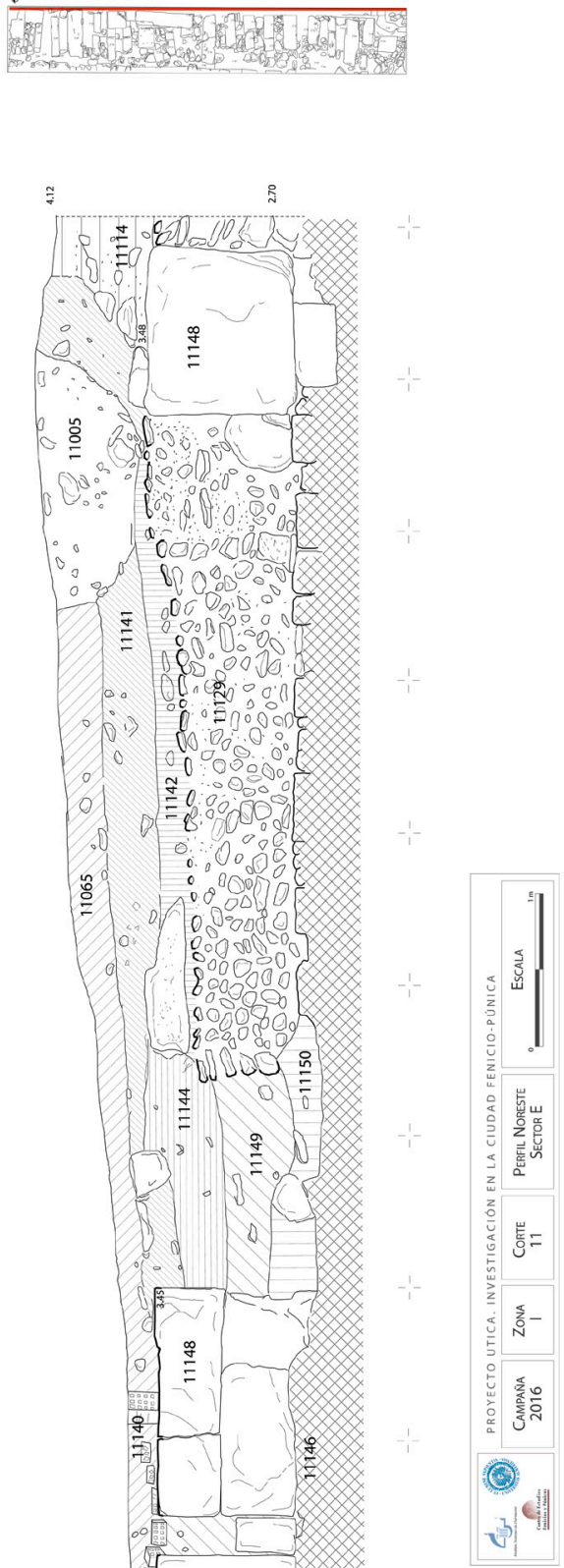


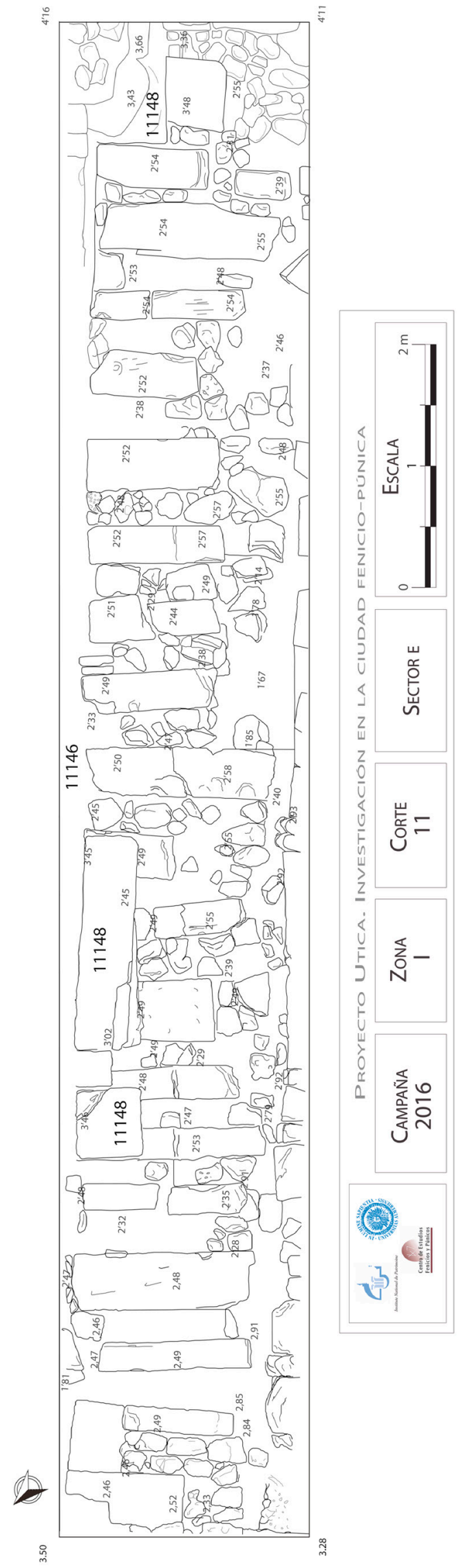



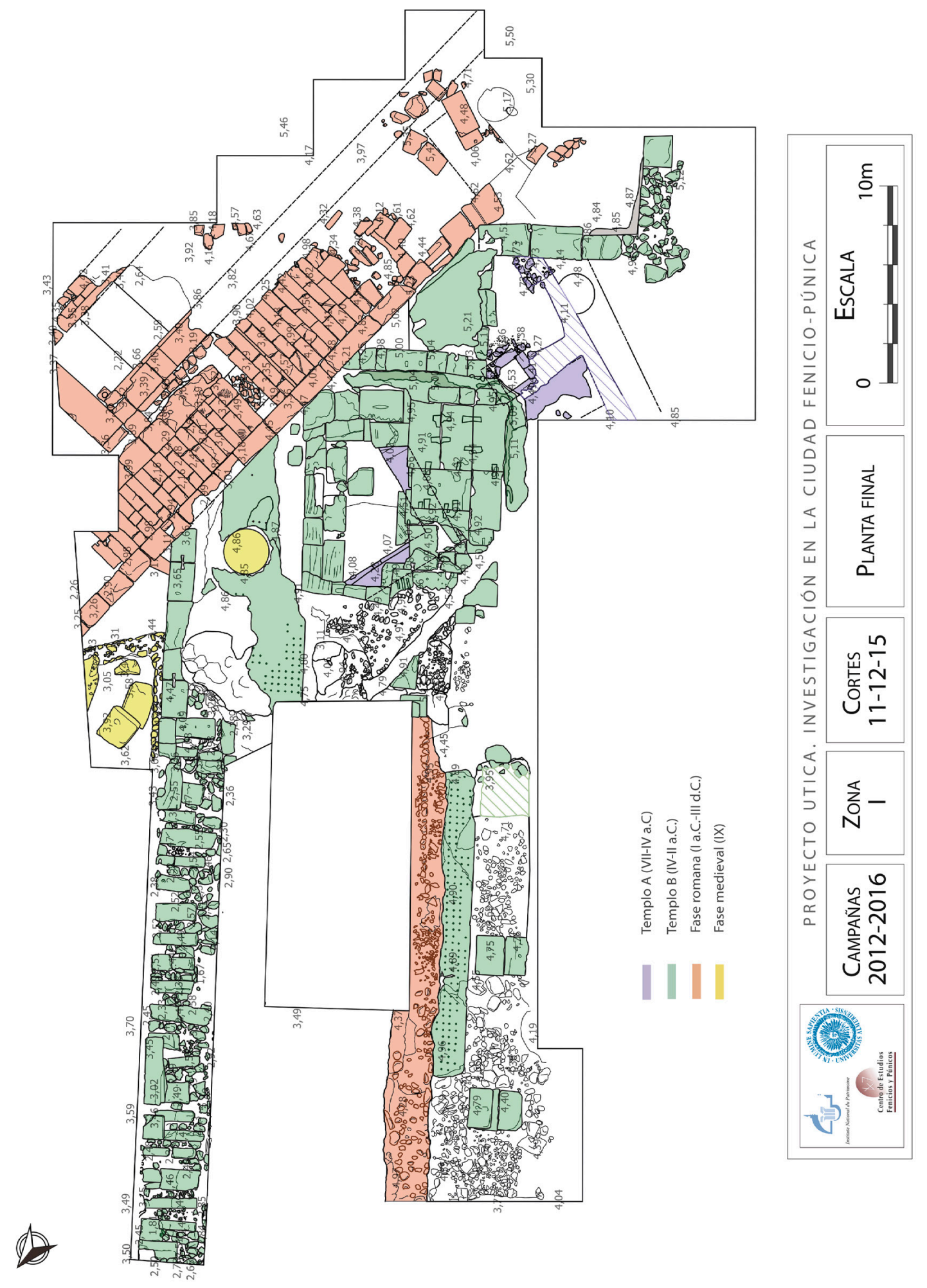
suelo de gran calidad, el pavimentum punicum I036I, con una superficie inferior a $6 \mathrm{~m}^{2}$. El pavimento, y posiblemente también la terraza de habitación de la que formaba parte dejaron de usarse a finales del siglo II a. C.y probablemente debió ser construido con anterioridad, a comienzos del siglo II o quizá en el siglo III a. C. Un aspecto a destacar es la importancia que supone registrar conjuntos cerámicos estratificados del siglo II a. C., especialmente en su segunda mitad, debido a que la destrucción de Cartago en I46 a. C. no hizo posible su presencia en el yacimiento que aporta los principales contextos cerámicos de buena parte del I milenio a. C. en el Norte de África.

El pavimento I036I fue cortado por muros edificados posteriormente, en una fase más tardía de época tardorrepublicana en la que se dispuso la canalización de agua IO2I4, descubierta en la campaña de 2013. En esta campaña se ha podido comprobar que seguía en dirección oeste y que fue cubierta por el muro roo64 del siglo i d. C. tras el que se sitúa un cardo bajo el que discurre una canalización de mayor tamaño I0278, posiblemente una cloaca. Ello podría estar indicando que la insula del siglo I d. C. debió ser trazada en época tardorrepublicana romana, con la consiguiente reordenación del espacio urbano uticense, señalada por el cambio de orientación de las edificaciones de época fenicio-púnica tardía.

Ya registrados en la prospección geofísica del año 20Io, los muros I0340 y IO34I situados en el extremo este del corte Io, sector 22 (figura I9) parecen delimitar una calle del periodo fenicio-púnico. Probablemente correspondan a los muros exteriores de dos manzanas o insulae de época fenicio-púnica, entre los que discurría una calle cuya datación deberá precisarse en futuras investigaciones. Ambos muros se asientan sobre la base geológica y forman parte de la retícula de edificaciones con la misma orientación de este periodo aportando un interesante elemento urbano hasta el momento no reconocido en la Utica fenicio-púnica, como es una vía pública con una anchura de 8 codos fenicio-púnicos de $0,52 \mathrm{~m}$, equivalentes a la separación de 4,20 m entre ellos. Además, el muro I0340 es de una anchura significativa, de I, $23 \mathrm{~m}$, lo que refuerza su posición como muro exterior de una edificación junto a una calle (figura 30). Este dato confirma la existencia de una morfología urbana ortogonal en Utica, lo que no debe ser extraño si pensamos que en Cartago se ha propuesto una morfología ortogonal en el desarrollo de la ciudad a partir de finales del siglo viII a. C. (Fumadó, 20I3: 274-276).

Finalmente, las prospecciones geofísicas efectuadas han suministrado resultados poco concluyentes en la zona 1B. En la zona $1 \mathrm{C}$ los resultados apuntan a la existencia de algunas posibles estructuras, mientras que en las zonas IIB y IIC parecen estar mejor definidas algunas estructuras enterrada de grandes dimensiones, pero que podrían estar arrasadas y rodeadas de derrumbes. 
Bibliografía

Bechtold, B. (2007): "La classe Byrsa 66r a Cartagine. Nuove evidenze per la tipologia e la cronologia di ceramica calena nella metropoli punica". Carthage Studies, I: I-36.

Bechtold, B. (2010): The Pottery Repertoire from Late $6^{\text {th }}-$ Mid $2^{\text {nd }}$ Century BC Carthage. Observations Based on the Bir Messaouda Excavations. Carthage Studies, 4. Ghent.

Ben Jerbania, I. (20I3): "Observations préliminaires sur la céramique archaïque d'Utique”. En J.-Y. Monchambert et alii (eds.): "Utique. Rapport préliminaire sur les deux premières campagnes de fouilles de la mission franco-tunisienne, 2oII et 2012". Cronique des activités archéologiques de l'École Française à Rome, 20I3: 45-50. <http://cefr.revues.org/996> (consulta 15/oI/202I).

Ben Jerbania, I., y Redissi, T. (2014): "Utique et la Méditerranée centrale à la fin du $\mathrm{IX}^{\mathrm{e}} \mathrm{s}$. et au viII ${ }^{\mathrm{e}} \mathrm{s}$. av. J.-C.: les enseignements de la céramique grecque géometrique". Rivista di Studi Fenici, 42: I77-204.

Ben Jerbania, I. (20I7): "La céramique sarde trouvée à Utique: quelle signification?”. Rivista di Studi Fenici, 45: I77-198.

Ben Jerbania, I. (2020): "L'horizon phénicien à Utique". En J.L. López Castro (ed.): Entre Utica y Gadir. Navegación y colonización fenicia en el Mediterráneo Occidental a comienzos del I milenio AC. LX Coloquio Internacional del Centro de Estudios Fenicios y Púnicos (Almería, 20I5). Editorial Comares. Granada: 3I-54. Ben Jerbania, I., López Castro, J.L., Sánchez Moreno, A., Ferjaoui, A., Fumadó, I., Mora, B., Ruiz Cabrero, L.A. y Abidi, F. (2020): "El área urbana fenicio-púnica del sector Norte de Utica”. En S. Celestino y E. Rodríguez (eds.): A Journey between East and West in the Mediterranean. IXInternational Congress of Phoenician and Punic Studies (Mérida, 20I8). I. IAM-CSIC. Mérida: 369-380.

Ben Jerbania, I., López Castro, J.L., Ferjaoui, A., Ferrer, E., Pardo, C.A., Peña, V., Jendoubi, K. y Khalfalli, W. (202I): "Architecture Phénico-punique dans le secteur des temples à Utique”. En L. Ben Abid, F. Prados y M. Grira (eds.): De Carthage à Carthagène. Bâtir en Afrique et en Ibérie durant l'Antiquité (Tunis-Dougga, 20I9). Universidad de Alicante. Alicante: 6r-9o.
Bikai, P.M. (1978): The pottery of Tyre. Aris \& Phillips. Warminster.

Bikai, P.M. (2003): "Statistical observations on the Phoenician pottery of Kition”. En V. Karageorghis (ed.): Kition VI, II: The Phoenician and Later Levels, Department of Antiquities. Cyprus. Nicosia: 23I-257.

Cardoso, J.L., López Castro, J.L., Ferjaoui, A., Mederos, A., Martínez Hahnmüller, V. y Ben Jerbania, I. (20I6): "What the people of Utica (Tunisia) ate in the $9^{\text {th }}$ century BC. Zooarchaeology of a North African early Phoenician settlement". Journal of Archaeological Science-Reports, 8: 314-322. <https://doi.org/Io.Ior6/j.jasrep.2016.06.org >.

Cibecchini, F. (2007): "La ceramica a vernice nera d'importazione dello scavo di Place Villeneuve-Bargemon a Marsiglia". Florentia: studi di archeologia, 2: 155-212.

Cibecchini F.y Capelli, C. (2013): "Nuovi dati archeologici e archeometrici sulle anfore greco-italiche: i relitti di III secolo del Mediterraneo occidentale e la possibilità di una nuova classificazione. En F. Olmer (ed.): Itinéraires des vins romains en Gaule III $-I^{e r}$ siècles avant J.-C. confrontation de faciès (Lattes, 2007). Monographies d'Archéologie Méditerranéenne, Hors-Série, 5. Association pour le Développement de l'Archéologie en Languedoc-Roussillon. Lattes: 423-45I.

Cintas, P. (1951): "Deux campagnes de fouilles à Utique”. Karthago, 2: I-88.

Cintas, P. (1954): "Nouvelles recherches à Utique". Karthago, 5: 89-I54.

Chelbi, F. (1996): Utique la splendide. Agence Nationale du Patrimoine. Tunis.

Delile, H., Abichou, A., Gadhoum, A., Goiran, J.-P., Pleuger, E., Monchambert, J.-Y., Wilson, A., Fentress, E., Quinn, J., Ben Jerbania, I. y Ghozzi, F. (2015): “The geoarchaeology of Utica (Tunisia): the palaeo-geography of the Mejerda delta and hypotheses concerning the location of the ancient harbour". Geoarchaeology, zo: 29I-306.

<https://doi.org/ıo.1002/gea.21514>. 
Ferrer, E., López Castro, J.L., Ben Jerbania, I., Pardo, C.A., Ferjaoui, A., Peña Romo, V. y Khalfali, W. (2020): "Los templos fenicio-púnicos del Sector Norte de Útica”. En S. Celestino y E. Rodríguez González (eds.): Un viaje entre el Oriente y el Occidente del Mediterráneo. IX Congreso Internacional de Estudios Fenicios y Púnicos (Mérida, 20I8). III. IAM-CSIC. Mérida: 393-405.

Freed, J. (1998): “Pottery Report”. En J. T. Peña, J. J. Rossiter, A.I. Wilson, C. Wells, M. Carroll, J. Freed y D. Godden (eds.): Carthage Papers. The Early Colony's Water Supply, a Public Bath, and the Mobilization of State Olive Oil. Journal of Roman Archaeology Supplement, 28. Portsmouth, RI: 18-63.

Fulford, M.G. (1994): “The Cooking and Domestic Wares”. En M.G. Fulford y D.P.S. Peacock (eds.): Excavations at Carthage. The British Mission II 2. The Circular Harbour, North Side. The Pottery. Oxford University Press. Oxford: 53-75.

Fumadó Ortega, I. (2013): Cartago fenicio-punica: arqueología de la forma urbana. Editorial Universidad de Sevilla. Sevilla.

García Sánchez,J. (20I6): "Las excavaciones del conde Byron Khun de Prorok en Cartago (I920-I925) III: Útica y Djerba". Boletín del Seminario de Estudios de Arte y Arqueología, 82: 225-250.

Goudineau, C. (1970): "Note sur la ceramique à engobe interne rouge-pompéien («Pompejanisch-Roten Platten»)". Mélanges d'archéologie et d'histoire, 82 (I): 159-186.

Guerrero, V.M. (1995): "La vajilla púnica de usos culinarios". Rivista di Studi Fenici, 23 (I): 6I-99.

Hayes, J.W. (1976): "Pottery. Stratified Groups and Typology”. En J.R. Humphrey (ed.): Excavations at Carthage 1975 Conducted by the University of Michigan I. Institut d'Archéologie et d'Art-American School of Oriental Research. Tunis: 47-Io8.

Herrera, M.D. y Gómez Toscano, F. (2004): Tell Abu Hawam (Haifa, Israel). El horizonte fenicio del Stratum III británico. Universidad Pontificia de Salamanca-Universidad de Huelva. Huelva.

Lamboglia, N. (1952): "Per una classificazione preliminare della ceramica campana”. I Congresso di Studi Liguri (Monaco, Bordighera, Genova, I950). Istituto Internazionale di Studi Liguri. Bordighera: 139-206.
Lancel, S. (1982): "Le carrefour des rues II et III, et les niveaux de rues". En S. Lancel (ed.): Byrsa II. Rapports préliminaires sur les fouilles 1977-I978: niveaux et vestiges puniques. Mission Archéologique française à Carthage. École Française de Rome. Rome: $13-43$.

Lancel, S. (1987): "La céramique punique d'époque hellénistique". Céramiques hellénistiques et romaines II. Annales littéraires de l'Université de Besançon, 33. Université de Franche-Comté. Besançon: 99-I38.

Lézine, A. (1968): Carthage, Utique. Études d'architecture et d'urbanisme. Éditions du Centre National de la Recherche Scientifique. Paris.

Lézine, A. (1970): Utique. Société tunisienne de diffusion. Tunis.

López Castro, J.L., Ferjaoui. A., Peña, J.A., Teixidó, T., Ghazouami, M., Adroher, A. y Ben Nejma, M. (20I2): "Proyecto Utica. Informe de los trabajos arqueológicos efectuados en la ciudad fenicio-púnica de Utica (Túnez). Campaña de 20I0". Informes y trabajos, 7: 360-37I.

López Castro,J.L., Ferjaoui, A., Adroher, A., Arbi, F., Ben Jerbania, I., Dridi, F., Essaadi, F., Ferrer, E., Fumadó, I., Martínez Hahnmüller, V., Mederos, A., Pardo, C.A., Peña, V.y Sánchez Moreno, A. (20I4): "Proyecto Útica. Investigación en la ciudad fenicio-púnica”. Informes y trabajos, II: 20I-2I9.

López Castro, J.L., Ferjaoui, A., Ben Jerbania, I., Jendoubi, K., Ferrer Albelda, E., Fumadó, I., Martínez Hahnmüller, V., Pardo, C.A., Sánchez Moreno, A., Fumadó, I., Mederos, A., Carpintero, S., Dhibi, C., Maldonado, G., Mora, B., Niveau, A., Peña, V., Souissi, I., Khalfalli, W., Dridi, F., Essaadi, F. y Ruiz Cabrero, L. (2015): "Proyecto Utica. Excavaciones en la ciudad fenicio-púnica. Campañas de 2013 y 20I4". Informes $y$ trabajos, I2: 259-280.

López Castro, J.L., Ferjaoui, A., Ben Jerbania, I., Martínez Hahnmüller, V., Pardo, C.A., Sánchez Moreno, A., Jendoubi, K., Mokrani, Y, Niveau, A., Ferrer, E., Mederos, A., Saidi, R., Abidi, F., Dhibi, C., Khalfalli, W., Mora, B., Peña, V. y Ruiz Cabrero, L. (20I6a): "Proyecto Utica. Excavaciones en la ciudad fenicio-púnica. Campaña de 20I5". Informes y trabajos, I4: II6-I3O. 
López Castro, J.L., Ferjaoui, A., Mederos, A., Martínez Hahnmüller, V. y Ben Jerbania, I. (20I6b): "La colonización fenicia inicial en el Mediterráneo Central. Nuevas excavaciones arqueológicas en Utica (Túnez)". Trabajos de Prehistoria, 73 (I): 68-89. $<$ https://doi.org/ro.3989/tp.20I6.I2164>.

López Castro, J.L., Ferjaoui, A., Ferrer, A., Pardo, C.A., Ben Jerbania, I. y Peña, V. (20I6c): "Edificios monumentales fenicio-púnicos en Utica". Aula Orientalis. Revista de Estudios del próximo Oriente Antiguo, 34 (2): 265-292.

López Castro,J.L., Ben Jerbania, I., Sánchez Moreno, A., Abidi, H., Abidi, F., Jendoubi, K., Ben Alí, R., Carpintero, S., Ferrer, E., Madahi, N., Mederos, A., Mora, B., Peña, V., Ruiz Cabrero, L.A. y Khalfalli, W. (2020a): "Excavaciones en la ciudad Fenicio-Púnica de Utica (Túnez). La campaña de 20I7". Aula Orientalis. Revista de Estudios del próximo Oriente Antiguo, 38 (2): 303-333.

López Castro, J.L., Ferjaoui, A., Mederos, A., Martínez Hahnmüller, V. y Ben Jerbania, I. (202ob): "Nouvelles recherches sur la période archaïque d’Utique”. En J.L. López Castro (ed.): Entre Utica y Gadir. Navegación y colonización fenicia en el Mediterráneo Occidental a comienzos del I milenio AC. IX Coloquio Internacional del Centro de Estudios Fenicios y Púnicos (Almería, 2015). Editorial Comares. Granada: 55-80.

López Castro, J.L., Ben Jerbania, I., Mederos, A., Ferjaoui, A., Martínez Hahnmüller, V. y Jendoubi, K. (2020c): "La primera ocupación fenicia de Utica". En S. Celestino y E. Rodríguez González (eds.): $U n$ viaje entre el Oriente y el Occidente del Mediterráneo. IX Congreso Internacional de Estudios Fenicios y Púnicos (Mérida, 20I8). III. IAM-CSIC. Mérida: I3I5-I326.

Martin-Kilcher, S. (1999): "Karthago 1993. Die Füllung eines frühkaiserzeitlichen Pozzo”. En Rakob. F. (ed.): Karthago III. Die Deutsche Ausgrabungen in Karthago. Philip von Zabern. Mainz: 403-434.

Morel, J.P. (198I): Céramique campanienne: les formes. École Française de Rome. Rome.

Niemeyer, H.G., Docter, R.F., Schmidt, K. y Bechtold, B. (2007): Karthago. Die Ergebnisse der Hamburger Grabung unter dem Decumanus Maximus. II. Hamburger Forschungen zur Archäologie, 2. Phillip von Zabern. Mainz.
Núñez Calvo, F. (2010): "Referencias secuenciales del repertorio cerámico fenicio metropolitano de la Edad del Hierro Tardío". En L. Nigro (ed.): Motya and the Phoenician ceramic repertoire between the Levant and the West, $9^{\text {th }}-6^{\text {th }}$ century $B C$ (Rome 20Io). Università di Roma La Sapienza. Roma: 49-83.

Perugini, A. (20I6): "Uzita: Preliminary Observations on the Middle and Late Punic Amphora Repertoire". En F. Schön y H. Töpfer (eds.): Karthago Dialoge. Karthago und der punische Mittelmeerraum-Kulturkontakte und Kulturtransfers im I. Jabrtausend vor Christus. Universität Tübingen. Tübingen: 175-185.

Peserico, A. (1996): Le brocche a fungo fenicie nel Mediterraneo: tipologia e cronologia. Collezione di Studi Fenici, 36. Consiglio Nazionale delle Ricerche. Roma.

Pleuger, E., Goiran, J.PH., Mazzini, I., Delile, H., Abichou, A., Gadhoum, A., Djerbi, H., Piotrowska, N., Wilson, A., Fentress, E., Ben Jerbania, I. y Fagel, N. (2019): "Palaeogeographical and palaeoenvironmental reconstruction of the Medjerda delta (Tunisia) during the Holocene". Quaternary Science Reviews, 220: 263-278. <https://doi.org/Io.Ior6/j.quascirev.2019.07.017>.

Puch Monge, S. (20I7): "Las cerámicas a mano, indígenas y fenicias". En H. Schubart y G.Maass-Lindemann (eds.): Morro de Mezquitilla.Die Phönizisch-Punische Niederlassung an der Algarrobo-Mündung.Madrider Beitrage, 33. Reichert Verlag. Wiesbaden: 156-210.

Py, M., Adroher, A.M. y Sanchez, C. (200I): Dicocer 2. Corpus des céramiques de l'Age du Fer de Lattes: (fouilles 1963-I999), I-2. Lattara, I4. Lattara.

Py, M. (1990): Culture, économie et société protohistoriques dans la région nimoise. Collection de l’École Française de Rome, rzr. École Française de Rome. Rome.

Ramon Torres, J. (1995): Las ánforas fenicio-puinicas del Mediterráneo Central y Occidental. Col-lecció Instrumenta, 2. Universidad de Barcelona. Barcelona.

Ramon Torres, J. y Maraui Telmini, B. (20II): "Les sondages dans la Zone 2”. En N. Kallala y J. Sanmartí (dirs.): Altbiburos I. La fouille dans l'aire du capitole et dans la nécropole méridionale. Institut Català d'Arqueologia Clàssica-Institut National du Patrimoine. Tarragona: 153-393. 
Sanmartí J., Ramon J.y Maraoui Telmini, B. (20I6): "La céramique préromaine modelée". En N. Kallala y J. Sanmartí (dirs.): Altbiburos II. L'aire du capitol et la nécropole méridionale: études. Institut Català d'Arqueologia Clàssica-Institut National du Patrimoine. Tarragona: 85-I40.

Sanmartí, J., Kallala, N., Belarte, M.C., Ramon, J., Maraoui Telmini, B., Jornet, R., Miniaoui, S., Fadrique, T., López, D., Morell, N., Portillo, M., Valenzuela, S., Campillo, J., Montanero, D., Cantero F. y Jenène, M. (20I2): "Filling Gaps in the Protohistory of the Eastern Maghreb: The Althiburos Archaeological Project (El Kef, Tunisia)". Journal of African Archaeology, io (I): 2I-44. <https://doi.org/IO.32I3/219I-5784-IO2I3>.

Sharon. I. (1987): "Phoenician and Greek Ashlar Construction Techniques at Tel Dor, Israel". Bulletin of the American School of Oriental Research, 267: 21-42. <https://doi.org/ıo.2307/1356965>.

Teixidó, T., Peña, J.A., López Castro, J.L., Ibáñez, A., Sierra, M. y Ferjaoui, A. (20I2): "Prospección magnética y georradar ${ }_{3} \mathrm{D}$ para delimitación y caracterización de yacimientos arqueológicos. Casos de estudio". I Congreso Internacional: El Patrimonio Cultural y Natural como motor de desarrollo: investigación e innovación (Jaén, 20II). Universidad Internacional de Andalucía. Sevilla: 2393-2407.
Thompson, H.A. (1934): "Two Centuries of Hellenistic Pottery". Hesperia, 3 (4): 3II-476.

Van der Meersch, C. (1994): Vins et amphores de grande Grèce et de Sicile, IVe-IIIe s. avant J.C. Centre Jean Berard. Naples.

Van der Werff, J. H. (1977-1978): "Amphores de tradition punique à Uzita”. Bulletin des antieke beschaving, 52-53: I71-198.

Vegas, M. (1999): "Phöniko-punische Keramik aus Karthago”. En Rakob. F. (ed.): Karthago III. Die Deutsche Ausgrabungen in Karthago. Philip von Zabern. Mainz: 93-219.

Verdan, S., Kenzelmann Pfyffer, A. y Léderrey, C. (2008): Céramique géométrique d'Érétrie. Eretria XX. Fouilles et recherches. École suisse d'archéologie en Grèce. Athens.

Will, E.L. (1982): “Greco-Italic Amphoras”. Hesperia, 51: $338-356$. 
ANEXO: Informe de la prospección geofísica con radar de subsuelo en Utica. Campaña de 2016

JosÉ ANTONIO PEÑA RUANO

Instituto Andaluz de Geofísica Aplicada

peruano@ugr.es

TERESA TEIXIDÓ ULLOD

Instituto Andaluz de Geofísica Aplicada

tteixido@ugr.es

OIER ARDANAZ OLAITZ

Investigación y Estudios de Geofísica Aplicada, S.L.

\section{Instrumentación utilizada y trabajo de campo}

En este estudio se ha utilizado como equipo transmisor-receptor un rádar de subsuelo monocanal modelo SIR 2000 (GSSI, Inc.) con una antena de $400 \mathrm{MHz}$, diseñada para explorar con buen detalle los primeros tres metros de profundidad. El trabajo de campo se realizó sobre los cuatro sectores prospectables, excluyendo únicamente las zonas de hondonadas o vegetación no desbrozada que impedían el paso de la antena.

En todos los casos se efectuaron perfiles paralelos con separación de $25 \mathrm{~cm}$ entre ellos, a lo largo de cada perfil se tomó un dato (traza) cada $2 \mathrm{~cm}$; todas las áreas se reconocieron con perfiles de ida y vuelta.

$\mathrm{Al}$ inicio de la adquisición de datos se efectuó un calibrado del instrumento para adecuarlo a las condiciones locales que consistió en adaptar la rueda marcadora a la rugosidad del suelo y amplificar la ganancia de las señales para las diferentes profundidades. Estos valores de calibración se ajustaron para adaptarse a sectores diferenciados de la prospección.

\section{Procesado de datos}

Para el procesado de cada perfil radar (radargrama) se ha utilizado el paquete específico Radan-6.6 de GSSI, pero para el tratamiento de imágenes ${ }_{3} \mathrm{D}$ y la gestión de mapas se han utilizado programas de desarrollo propio y estándares de ofimática. Se han ensayado varios flujos de procesado multiseñal para cada zona y finalmente se ha optado por un tratamiento donde, aparte de la aplicación de filtros pasa-banda, los dos pasos más significativos han sido una migración (Kirchoff) y una eliminación específica del bandeado horizontal residual.

Una vez procesados todos los perfiles se ha procedido a la reconstrucción $3 \mathrm{D}$ que empieza por ordenar los radargramas según la geometría de adquisición y promediar las amplitudes de reflexión espacialmente. Con el volumen $3 \mathrm{D}$ construido, se procede a su análisis y manipulación con el objeto de confeccionar imágenes radar ${ }_{3} \mathrm{D}$ del subsuelo investigado (cortes horizontales, anomalías volumétricas, etc.).

\section{Resultados}

\section{Zona I sector Ib}

Es muy probable que en la parte central y al suroeste las reflexiones se deban a cambios edafológicos y a raíces. Las fuertes reflexiones de la parte norte albergan más posibilidades de que sean estructuras asociadas (¿muros?).

\section{Zona I sector lb}

En este sector se han detectado débiles reflectores y solo a nivel superficial, hasta los $20 \mathrm{~cm}$ de profundidad aproximada. La geometría de estos reflectores es también poco clara; de modo que, si se tratase de estructuras, estas estarían muy arrasadas y con derrumbes asociados (figura 38 )

\section{Zona II sector $2 b$}

En el nivel superficial se han detectado varios elementos metálicos y en la parte norte se observan hipérbolas sin organización visible producidas por algunas raíces y, con poca probabilidad, por débiles estructuras con derrumbes asociados. En la zona central se localiza el techo de un reflector circular que podría ser un resto de alguna estructura o tal vez un antiguo tocón de árbol. El Segundo nivel, por debajo los $20 \mathrm{~cm}$ de profundidad, aparecen reflexiones, donde las que rodean a al reflector central parecen disponerse en forma circular por lo que podría tratarse de antiguas raíces. 


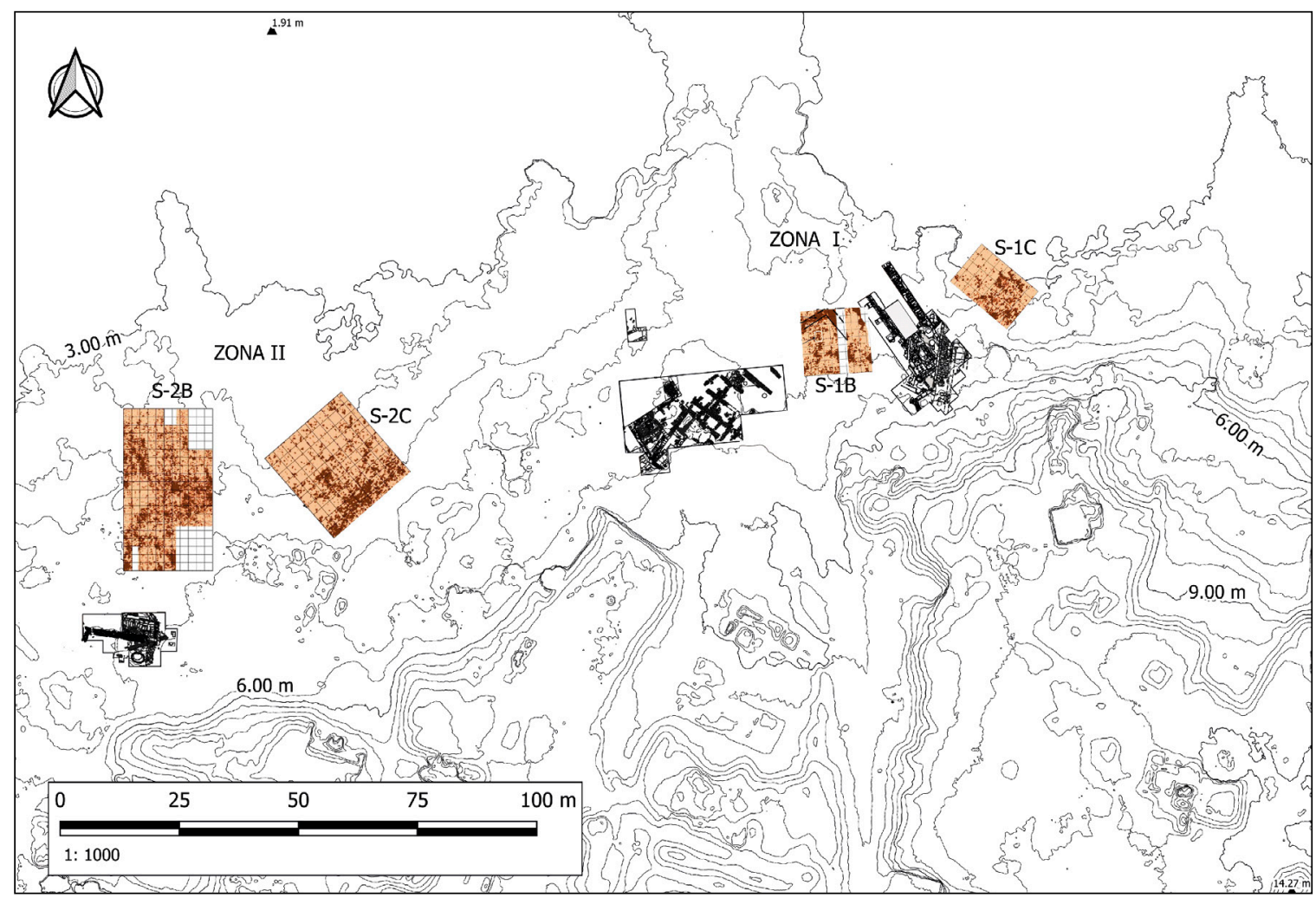

Figura 38. Plano de los sectores prospectados on geo-radar en 2016

Figure 38. Plan of Ground Penetrating Radar survey sectors in 2016

En el caso de que se tratase de restos de estructuras y no de raíces y bloques, la disposición espacial de los reflectores: cortos, dispersos y sin geometrías evidentes, indica un sector que alberga estructuras muy arrasadas y derrumbadas.

\section{Zona II, Sector 2C}

$\mathrm{Al}$ igual que en el sector anterior las reflexiones detectadas son cortas y con una distribución espacial dispersa que de no estar un yacimiento rico en estructuras cabría interpretarlas como restos vegetales y/o bloques y cantos esparcidos.

Para el nivel superficial la mayoría de reflexiones se localizan en una banda de $4 \mathrm{~m}$ de ancho que discurre paralela al eje X. También se observa una concentración de reflexiones alrededor del puno $(5, \mathrm{IO})$ cuya disposición presenta algún rasgo geométrico (líneas discontinuas).

En el segundo nivel la banda de reflectores de la parte sur adquiere algún rasgo lineal que podría ser indicativo de restos murarios muy arrasados, donde alguno de ellos se define mejor hacia el nivel base.
Casi en torno al eje $\mathrm{X}=\mathrm{o}$ se ha detectado un reflector lineal que desaparece hacia el metro $X=15 . \mathrm{Si}$ no se trata del borde de un camino, podría ser el inicio de una estructura. Este reflector se detecta en los niveles anteriores, pero es en este nivel base cuando se hace más visible.

\section{Consideraciones finales}

A diferencia de la campaña geofísica realizada en el año 2010 en la Zona I-A y la Zona II-A donde se obtuvieron muy buenos resultados georradar (informe ref. AGA-78), la exploración georradar en la campaña de 2016 ha sido menos exitosa, ya que en todas las zonas exploradas la disposición de los reflectores ha sido muy dispersa y sin apenas presentar tendencias geométricas que pudieran indicar una clara planimetría de las posibles estructuras arqueológicas. Por otra parte, los pocos reflectores potentes se han prestado a una interpretación dudosa ya que la mayoría de ellos, debido a su emplazamiento cercano a la vegetación o a caminos, podía tener un origen edafológico. 